\title{
The Role of KNDy Neurons and Neuronal Nitric Oxide Synthase in the Control of Reproduction in Female Sheep and Nonhuman Primates
}

Michelle Nichole Bedenbaugh

Follow this and additional works at: https://researchrepository.wvu.edu/etd

\author{
Recommended Citation \\ Bedenbaugh, Michelle Nichole, "The Role of KNDy Neurons and Neuronal Nitric Oxide Synthase in the \\ Control of Reproduction in Female Sheep and Nonhuman Primates" (2018). Graduate Theses, \\ Dissertations, and Problem Reports. 5174. \\ https://researchrepository.wvu.edu/etd/5174
}

This Dissertation is protected by copyright and/or related rights. It has been brought to you by the The Research Repository @ WVU with permission from the rights-holder(s). You are free to use this Dissertation in any way that is permitted by the copyright and related rights legislation that applies to your use. For other uses you must obtain permission from the rights-holder(s) directly, unless additional rights are indicated by a Creative Commons license in the record and/ or on the work itself. This Dissertation has been accepted for inclusion in WVU Graduate Theses, Dissertations, and Problem Reports collection by an authorized administrator of The Research Repository @ WVU.

For more information, please contact researchrepository@mail.wvu.edu. 
The Role of KNDy Neurons and Neuronal Nitric Oxide Synthase in the Control of Reproduction in Female Sheep and Nonhuman Primates

\author{
Michelle Nichole Bedenbaugh \\ Dissertation submitted to the College of Medicine at West Virginia University \\ In partial fulfillment of the requirements for the degree of \\ Doctor of Philosophy in Cellular and Integrative Physiology \\ Robert Goodman, Ph.D., Chair \\ Stanley Hileman, Ph.D., Mentor \\ Robert Dailey, Ph.D. \\ Steven Hardy, Ph.D. \\ James Simpkins, Ph.D. \\ Department of Physiology, Pharmacology and Neuroscience \\ Morgantown, West Virginia \\ 2018
}

Keywords: Puberty, sheep, kisspeptin, GnRH, nitric oxide

Copyright 2018 Michelle Nichole Bedenbaugh 


\section{ABSTRACT \\ The Role of KNDy Neurons and Neuronal Nitric Oxide Synthase in the Control of Reproduction in Female Sheep and Nonhuman Primates Michelle Nichole Bedenbaugh}

Gonadotropin-releasing hormone $(\mathrm{GnRH})$ secretion from the hypothalamus is an important regulator of ovarian function and reproductive cyclicity. During the reproductive cycle, the pattern of GnRH secretion from the hypothalamus, and subsequently luteinizing hormone (LH) secretion from the anterior pituitary, is modulated by ovarian hormones. However, the effects of estradiol $\left(E_{2}\right)$ and progesterone cannot be directly communicated to GnRH neurons because these neurons do not express progesterone receptors or estrogen receptor alpha (ER $\alpha)$, the estrogen receptor that influences estrogenic regulation of GnRH secretion. Thus, neuronal intermediates that do express these receptors must exist to communicate steroidal feedback to GnRH neurons. Kisspeptin, neurokinin B (NKB), dynorphin, and neuronal nitric oxide synthase (nNOS) are all neuronal intermediates that may participate in the communication of steroidal feedback.

Increased GnRH secretion is critical for puberty onset. Neurokinin B and dynorphin may play a role in regulating GnRH secretion during pubertal development, as senktide, an NKB receptor (NK3R) agonist, and nor-BNI, a kappa-opioid receptor (KOR) antagonist, stimulate LH secretion in prepubertal ewes. However, where these effects occurred within the hypothalamus was unknown. Thus, we examined whether senktide or nor-BNI placement in the arcuate nucleus (ARC) or preoptic area (POA) would increase LH secretion in prepubertal ewes. Placement of senktide-containing microimplants into either the ARC or POA significantly increased mean LH concentrations. In contrast, nor-BNI-containing microimplants had no effect 
on LH secretion when placed in either the ARC or POA. Additionally, the influence of $\mathrm{E}_{2}$ or age on NK3R expression in several hypothalamic areas was also investigated. Estradiol did not significantly alter NK3R cell numbers in any of the areas examined. However, there was a significant increase in the number of NK3R neurons in the POA of adult ewes compared to prepubertal ewes. Further work will be necessary to determine how and where dynorphin is acting in prepubertal ewes to inhibit LH secretion. However, changes in the NKB/NK3R system, particularly within the POA, may play a role in the pubertal increase in LH secretion in ewes.

Nitric oxide (NO), a gaseous neurotransmitter synthesized by nitric oxide synthase (NOS), is another neuronal intermediate that may play an integral role in GnRH secretion and puberty onset. Therefore, we sought to neuroanatomically characterize nNOS expression in prepubertal ewes and determine if $E_{2}$ would exert effects on this system. Neurons immunoreactive for nNOS were identified in several areas in prepubertal ewes, including the POA, ARC, and ventrolateral portion of the ventromedial hypothalamus. Moreover, nNOS neurons colocalized with ER $\alpha$, kisspeptin, and GnRH. However, neither the number of nNOS neurons in the POA or hypothalamus, nor the percentage of nNOS coexpression with $\mathrm{ER} \alpha$, kisspeptin, or GnRH were influenced by $\mathrm{E}_{2}$. These experiments reveal that nNOS is abundantly expressed in the prepubertal sheep hypothalamus, a portion of nNOS neurons contain $\mathrm{ER} \alpha$, and a neuroanatomical relationship exists between both nNOS and kisspeptin and nNOS and GnRH. Therefore, nNOS may act both directly and indirectly to influence GnRH secretion in prepubertal sheep.

Because our results in prepubertal sheep were in contrast to what has previously been reported in adult rodents, we also determined if nNOS colocalized with kisspeptin and GnRH in 
adult female sheep and primates. Similar to prepubertal ewes, kisspeptin neurons in adult ewes were highly colocalized with nNOS. In contrast, no colocalization was observed between kisspeptin and nNOS in adult female primates. Gonadotropin-releasing hormone neurons also colocalized with nNOS in adult ewes and primates, albeit to a much lesser extent than what was observed in prepubertal ewes. Thus, although there are species differences, a neuroanatomical relationship exists between nNOS and kisspeptin and nNOS and GnRH in adult female primates and sheep. 


\section{DEDICATION}

This dissertation is dedicated to my parents, Steve and Chris Bedenbaugh, and my brother,

Robby Bedenbaugh, who have always been there to offer advice and support. You da real MVPs! 


\section{ACKNOWLEDGEMENTS}

I would first like to thank Dr. Stan Hileman for his continuous support and advice throughout my doctoral studies and the completion of this dissertation. In addition, I would like to thank him for aiding me in publishing my Master's research in the absence of Marcel. While certainly not as important, I'd also like to thank him for breaking up the work day with the discussion of sports and introducing me to the luxuries of suites and field passes at WVU baseball and football games. I'd also like to give a special thanks to Dr. Bob Goodman who basically served as a second mentor. Thank you for all of your help, advice, and most importantly, for answering your phone when Rick and I had no idea how to read a particular x-ray and Stan wasn’t answering his phone. Thanks also to Dr. Bob Dailey, Dr. Steve Hardy, and Dr. Jim Simpkins for your willingness to serve on my committee and Dr. Kellie Breen for serving as my external examiner. To Gail Sager and Miro Valent, I cannot thank the two of you enough for the countless hours you spent taking care of animals, helping with animal surgeries, ordering supplies, making paraformaldehyde, and completing LH assays. You made my graduate life exponentially easier, and I will be forever grateful. Special thanks to Lizzie Bowdridge and Ashley Lindo (Who run the world?!), Rick McCosh, and Justin (and Dustin...and Jason) Lopez for your friendship as well as your help with animal and laboratory work. To my undergraduates, Catherine Ransom, Ryan O’Connell, Anne Burdette, and Brandon Wisman, thank you for your assistance with my experiments and for giving me the opportunity to teach you a little bit about the brain and puberty. To Lindsey Bishop, Danielle Shepherd, Kristina Marinak, Dylan Boehm, Dudley McNitt, Tanya Dilan, Katie Roach and the rest of my fellow graduate students, my workout buddies, and my family, thank you for always being available to chat, enjoy life, road trip, and eat delicious food. Soph, thanks for always showing excitement when I arrived home (no matter 
the time of day), for your constant need for love and attention, and for being the best running buddy for which I could ask (except for that lovely period of time when both of us were sidelined).

Thank you to everyone who helped me throughout my graduate career at WVU. Your support aided in my success. 


\section{TABLE OF CONTENTS}

\section{Contents}

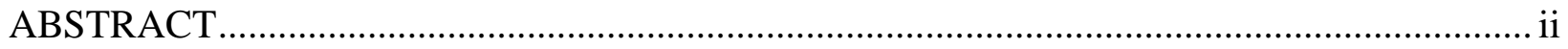

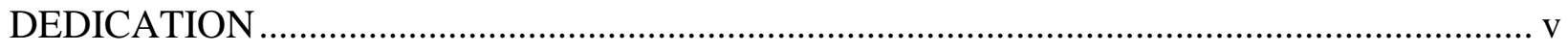

ACKNOWLEDGEMENTS ............................................................................................ vi

TABLE OF CONTENTS .................................................................................................

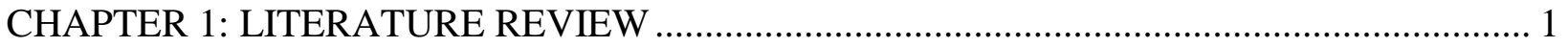

CONTROL OF REPRODUCTIVE CYCLICITY: ESTROUS CYCLES IN SHEEP ................. 2

THE GnRH NEURONAL NETWORK AND CONTROL OF ESTROUS CYCLICITY .......... 5

BRIEF OVERVIEW OF THE SEASONAL CONTROL OF THE ESTROUS CYCLE IN

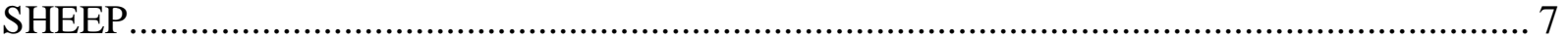

CONTROL OF REPRODUCTIVE CYCLICITY: MENSTRUAL CYCLES IN PRIMATES . 8

NEUROENDOCRINE BASIS OF PUBERTAL DEVELOPMENT ……………………........ 10

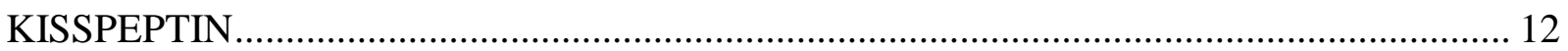



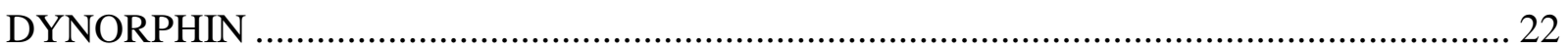

NITRIC OXIDE/NEURONAL NITRIC OXIDE SYNTHASE ................................................. 26

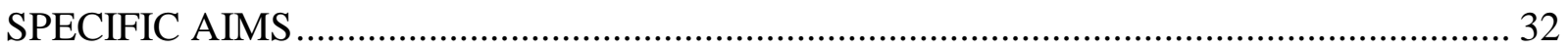

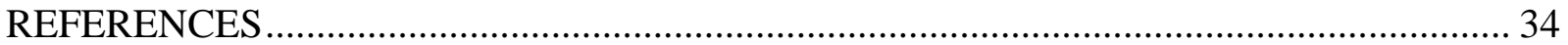

CHAPTER 2: POTENTIAL IMPORTANCE OF THE NKB/NK3R SYSTEM IN THE PREOPTIC AREA FOR PUBERTY IN FEMALE SHEEP ....................................................... 75

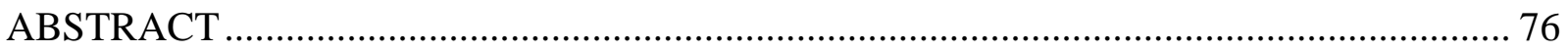

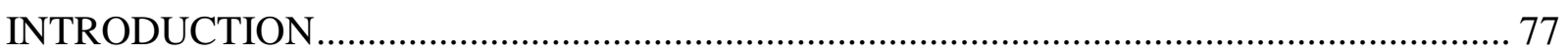

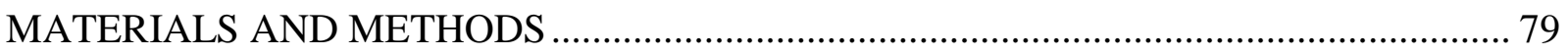

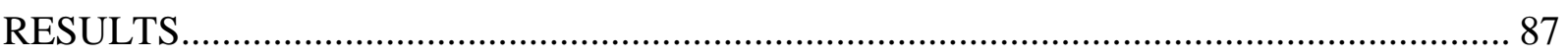

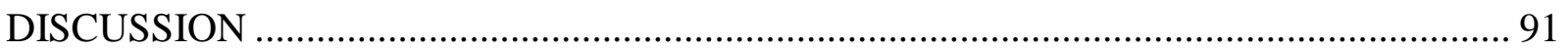

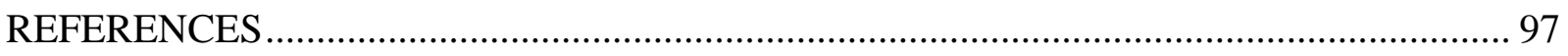



CHAPTER 3: KISSPEPTIN, GnRH, AND ER $\alpha$ COLOCALISE WITH nNOS NEURONS IN PREPUBERTAL FEMALE SHEEP ………………................................................. 111

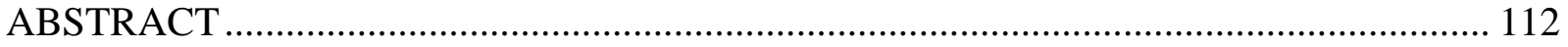

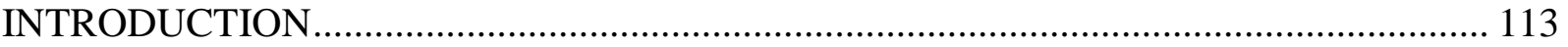

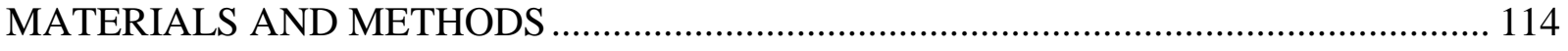

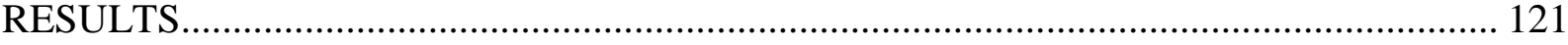






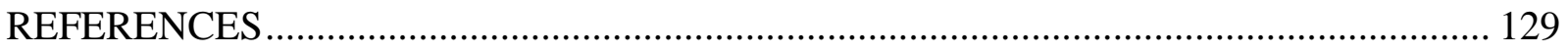

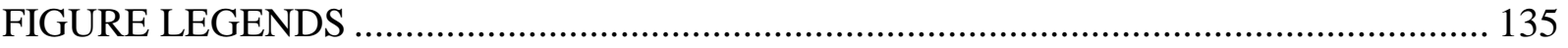

CHAPTER 4: NEUROANATOMICAL RELATIONSHIP OF nNOS TO GnRH AND KISSPEPTIN NEURONS IN ADULT FEMALE SHEEP AND PRIMATES ........................... 148

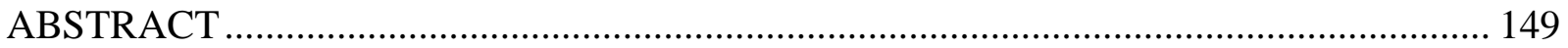



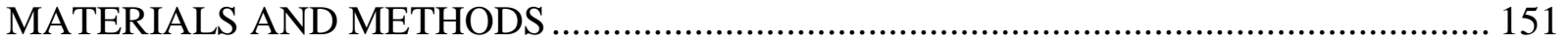

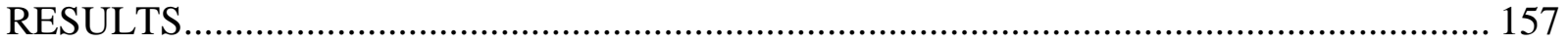

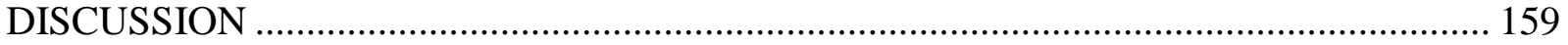

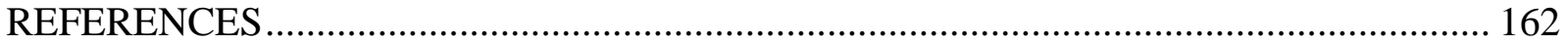

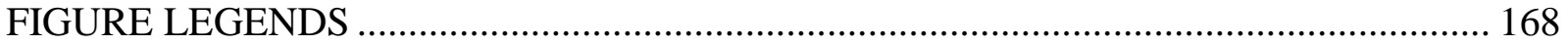

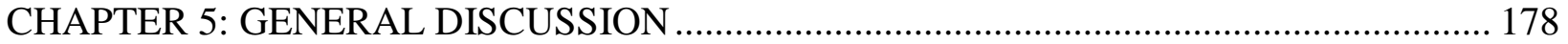

NKB AND DYNORPHIN IN PUBERTY ................................................................ 180

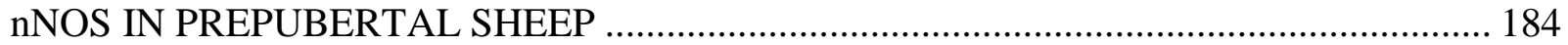

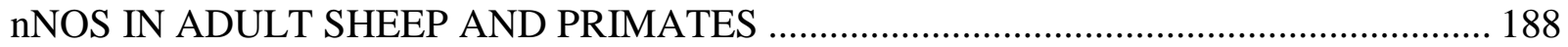

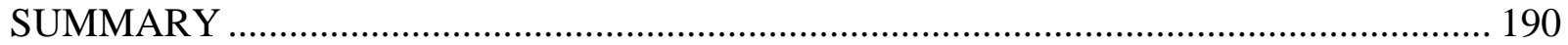




CHAPTER 1

LITERATURE REVIEW 


\section{CONTROL OF REPRODUCTIVE CYCLICITY: ESTROUS CYCLES IN SHEEP}

Female reproduction relies upon cyclical changes in ovarian function. In sheep, this culminates in a 14-19 day estrous cycle which consists of a 2-3 day follicular phase and a 13-14 day luteal phase (1). Most strains of mice (2) and rats (3) also exhibit estrous cycles. Estrous cycles in rodents are much shorter (4-5 days) and consist of four stages: proestrus, estrus, metestrus, and diestrus. Estrous cycles in the ewe are similar to other species of animals that spontaneously ovulate and have functional luteal phases with the exception that the follicular

phase in ewes is much shorter to that in primates (approximately 14 days) (4). In addition, ewes are seasonal breeders and undergo seasonal anestrus during a portion of the year when day length is long. Estrous cyclicity is eventually restored when day length shortens (5). This allows for lambs to be born in the spring, a period which maximizes survivability.

Expression of a functional estrous cycle is made possible through the coordinated interaction among four main tissues; brain, pituitary, ovary and uterus. Several critical hormones are synthesized and secreted from these tissues, including gonadotropin-releasing hormone $(\mathrm{GnRH})$ from the hypothalamus, luteinizing hormone (LH) and follicle-stimulating hormone (FSH) from the anterior pituitary, estradiol $\left(\mathrm{E}_{2}\right)$, inhibin, and progesterone from the ovary, and prostaglandin $\mathrm{F}_{2 \alpha}\left(\mathrm{PGF}_{2 \alpha}\right)$ from the uterus and corpora lutea (CL) (5).

Throughout the ovine estrous cycle, there are two modes of GnRH and $\mathrm{LH}$ secretion (tonic or surge secretion) which control different aspects of ovarian function. During tonic secretion, GnRH and LH are released in a pulsatile pattern at low concentrations throughout the cycle. This form of hormone secretion is regulated by negative-feedback actions of $E_{2}$ and progesterone and is imperative for ovarian steroidogenesis and the initial stages of follicular development. The second mode of $\mathrm{GnRH} / \mathrm{LH}$ secretion is surge secretion. This mode of secretion occurs in the 
late follicular phase of the estrous cycle when circulating concentrations of $E_{2}$ are high. Within 4 to 8 hours, LH concentrations rise 50-100 times higher than basal concentrations and then rapidly decline. In total, the LH surge lasts approximately 12 hours and ovulation normally occurs 22-26 hours after this surge (5). Concentrations of GnRH also increase 20-40 times above basal GnRH concentrations as GnRH secretion transitions from a pulsatile to a more continuous pattern of release $(6,7)$. During the early phases of the surge, GnRH and LH release is relatively synchronous. However, GnRH secretion remains elevated for several hours even after the LH surge is complete (6). Whether this prolongation of GnRH release is of any functional significance remains unclear. The GnRH/LH surge ultimately results in the ovulation of an oocyte and the formation of a CL.

Ovarian hormones are also an integral component of the estrous cycle in sheep. Progesterone is secreted into the circulation by the CL and $\mathrm{E}_{2}$ is secreted by follicle(s). Little to no circulating progesterone is present early in the estrous cycle immediately following ovulation. As the amount of luteal tissue increases from day 2-8, progesterone concentrations also increase and eventually peak around $1.5-4 \mathrm{ng} / \mathrm{ml}(5,8,9)$. Progesterone concentrations remain relatively constant from day 8-14 and subsequently decline back to undetectable concentrations (10). In sheep, the LH surge does not cause an increase in circulating progesterone (11) which is in contrast to what occurs in rats and primates $(12,13)$. Whether this difference is of any functional significance remains to be determined. However, progesterone does increase within preovulatory follicles and is associated with the ovulatory process (14). When progesterone concentrations decrease after luteolysis, $\mathrm{E}_{2}$ secretion begins to increase (11). During the next few days of the estrous cycle, $E_{2}$ concentrations increase 5- to 10-fold and peak at the beginning of the LH surge $(8,15)$. Ultimately, progesterone inhibits GnRH and LH pulse frequency in a 
dose-dependent manner while $\mathrm{E}_{2}$ inhibits $\mathrm{GnRH}$ and LH pulse amplitude and stimulates $\mathrm{GnRH}$ and LH pulse frequency (16). In addition, $\mathrm{E}_{2}$ enhances the inhibitory actions of progesterone, but this effect is not dose-dependent (16). Throughout the estrous cycle, inhibition by $\mathrm{E}_{2}$ on GnRH and LH pulse amplitude remains relatively constant while GnRH and LH pulse frequency is inversely correlated with progesterone concentrations.

By influencing GnRH and LH secretion, ovarian hormones also play an important role in folliculogenesis. While the idea that follicular waves occur in sheep remains controversial, cycles of follicular development are usually preceded by an increase in FSH concentrations. If a follicular wave is defined as $3 \mathrm{~mm}$ follicles growing to at least $5 \mathrm{~mm}$ in diameter, 2-6 follicular waves occur during the sheep estrous cycle, and ovulatory follicles arise from either the ultimate or penultimate wave (17-19). On the day before the GnRH/LH surge, FSH concentrations decline to a nadir (in part due to increasing inhibin release) and subsequently surge in conjunction with LH $(10,20)$. After the surge, FSH concentrations decline until a second peak occurs 20-28 hours after the first. Throughout the luteal phase, FSH concentrations rise and fall in 3-6 day intervals, and peaks of FSH concentrations precede each wave of follicular development (20-22).

The GnRH and LH surge initiate the ovulatory cascade in follicles which results in the rupture of the follicle and release of an oocyte. When the LH surge occurs, increases in 3'5' cyclic adenosine monophosphate (cAMP) are triggered. Increasing cAMP concentrations inhibit $\mathrm{E}_{2}$ synthesis from progesterone which causes an increase in progesterone in the follicle (5). The intrafollicular increase in progesterone initiates an increase in both prostaglandin $\mathrm{E}_{2}\left(\mathrm{PGE}_{2}\right)$ and $\mathrm{PGF}_{2 \alpha}$. Prostaglandin $\mathrm{E}_{2}$ increases proteolytic activity and causes hyperemia within the follicle. Prostaglandin $\mathrm{F}_{2 \alpha}$ induces contractions of smooth muscle-type cells in the wall of the follicle (5). 
In addition to initiating the ovulatory cascade, LH also stimulates the secretion of urokinase-type plasminogen activator (uPA) which converts plasminogen to plasmin. This conversion prompts increases in collagenases within the follicular wall as well as the release of tumor necrosis factor alpha $\left(\mathrm{TNF}_{\alpha}\right)(5)$. Progesterone and prostaglandins, as well as matrix metalloproteinases, which increase in response to $\mathrm{TNF}_{\alpha}$, cause a degradation of the apical follicular wall. This degradation continues to occur until the stigma is formed, the follicle ruptures, and the oocyte is released (5).

\section{THE GnRH NEURONAL NETWORK AND CONTROL OF ESTROUS CYCLICITY}

Gonadotropin-releasing hormone neurons are present throughout the preoptic area (POA) and hypothalamus of sheep. Approximately 50\% of GnRH neurons are located in the POA and the remainder are found in the diagonal band of Broca (DBB), anterior hypothalamic area (AHA), and mediobasal hypothalamus (MBH) (23). While there is evidence for the existence of anatomical and functional subpopulations of GnRH neurons, there are no regional differences in the percentage of GnRH neurons that project to the median eminence (24). Therefore, GnRH terminals located in the external zone of the median eminence arise from GnRH neurons throughout the POA and hypothalamus.

Because GnRH neurons do not contain progesterone receptors (25) or estrogen receptor alpha $\left(\mathrm{ER}_{\alpha}\right)(26,27)$, the estrogen receptor isoform important for mediating the effects of $\mathrm{E}_{2}$ on $\mathrm{GnRH}$ secretion, other neuronal intermediates that do contain these receptors must exist to communicate $\mathrm{E}_{2}$ and progesterone feedback to GnRH neurons. Several intermediates have been hypothesized, including dopamine (26, 28), gamma-aminobutyric acid (GABA) (27), glutamate (29), norepinephrine (30, 31), dynorphin (32), $\beta$-endorphin (26), neurokinin B (NKB) (33),

neuropeptide Y (NPY) (28), somatostatin (34), galanin (35), orphanin-FQ (OFQ) (36), RF-amide 
related peptide 3 (RFRP3) (37), and kisspeptin $(38,39)$. In recent years, a considerable amount of attention has been focused on kisspeptin, NKB, and dynorphin. Colocalization of all three of these neuropeptides is only found within the arcuate nucleus (ARC), and this population of neurons has been given the name "KNDy" neurons (40). These neurons project to the median eminence where they may contact GnRH terminals to influence GnRH secretion (41), and approximately one-third of GnRH perikarya in the POA and 40\% of GnRH cell bodies in the MBH are contacted by fibers from KNDy neurons (42). Additionally, KNDy neurons also contain ER $\alpha$ and progesterone receptors $(39,43,44)$. Thus, KNDy neurons are excellent candidates for communicating $\mathrm{E}_{2}$ and progesterone feedback to $\mathrm{GnRH}$ neurons and may drive pulsatile GnRH secretion.

For GnRH to be secreted in an episodic manner, GnRH neurons most likely function in synchrony (45), and KNDy neurons may play a role in the generation of these GnRH pulses. Several experiments have provided evidence that KNDy neurons contribute to the generation of GnRH pulses. First, kisspeptin is critical for episodic LH secretion in ovariectomized (OVX) ewes $(46,47)$. Moreover, KNDy neurons are a part of an extensive interconnected network which is capable of firing in synchrony $(48,49)$, and project to $\mathrm{GnRH}$ neurons throughout the POA and hypothalamus (42). Bursts of multi-unit activity (MUA), which correlate well with LH pulses, have also been recorded from KNDy neurons in OVX goats (50). Based on this and other information, a model was created to propose specific roles for each KNDy peptide in the generation of a GnRH pulse. It is hypothesized that kisspeptin provides the final output signal from KNDy neurons which thereby initiates a GnRH pulse. This action is possible because GnRH neurons contain kisspeptin receptors (KISS1Rs) (51), but KNDy neurons themselves do not (41). Moreover, kisspeptin administration increases LH secretion without affecting MUA in 
the ARC (50). In contrast to kisspeptin, NKB most likely does not act directly on GnRH neurons, because GnRH neurons do not contain neurokinin 3 receptors (NK3Rs) (52). However, KNDy neurons do contain NK3R (52). Thus, NKB may exert autocrine or paracrine effects on KNDy neurons to initiate a positive-feedback loop within the KNDy network to generate a GnRH pulse. Evidence that intracerebroventricular (ICV) administration of an NK3R agonist increases MUA activity (53) and c-Fos (54), a marker of neuronal activation, in KNDy neurons supports this idea. Administration of an NK3R antagonist into the ARC also disrupts LH secretion and further supports the concept that NKB participates in the creation of a GnRH pulse by acting on KNDy neurons in the ARC (55). Dynorphin, the final peptide of the KNDy trifecta, serves to decrease and eventually terminate KNDy neural activity and thus a GnRH pulse. Infusion of naloxone, a general opioid receptor antagonist, increases GnRH pulse amplitude and prolongs pulse duration (56). Similarly, ICV administration of a $\kappa$-opioid receptor (KOR) antagonist increases MUA frequency in the ARC (53), and administration of this antagonist directly to the ARC increases LH pulse frequency (55). Altogether, it appears that kisspeptin, $\mathrm{NKB}$, and dynorphin work together to control the generation of GnRH pulses. Alterations in the frequency of these GnRH pulses regulate reproductive processes such as seasonal breeding, estrous cyclicity, and the pubertal transition.

\section{BRIEF OVERVIEW OF THE SEASONAL CONTROL OF THE ESTROUS CYCLE IN SHEEP}

In the ewe, photoperiod exerts control over the estrous cycle through an interaction between day length and the endogenous circannual rhythm (57). One of the main responses this interaction controls is a significant seasonal variation in $E_{2}$ negative feedback (58). During the 
breeding season, progesterone serves as the primary inhibitor of GnRH and LH pulse frequency. After luteolysis, progesterone concentrations fall. This results in an increase in GnRH and LH pulse frequency which stimulates the secretion of $E_{2}$ from the ovary, the LH surge, and ovulation (5). During the shorter days of the breeding season, $\mathrm{E}_{2}$ does not inhibit GnRH and LH pulse frequency and only modestly inhibits mean LH concentrations. When an animal transitions into anestrus during the longer days of spring and early summer, there is a switch from progesterone functioning as the major inhibitor of $\mathrm{GnRH}$ and $\mathrm{LH}$ secretion to $\mathrm{E}_{2}$ being the major inhibitory factor. Thus, $\mathrm{E}_{2}$ now suppresses GnRH and LH pulse frequency and strongly inhibits mean LH concentrations (5). Anestrus persists until day length becomes shorter in autumn and $E_{2}$ negative feedback no longer inhibits LH pulse frequency. Luteinizing hormone secretion once again increases, $\mathrm{E}_{2}$ concentrations rise, the LH surge is initiated and ovulation occurs (5). Because $\mathrm{E}_{2}$ negative feedback predominates during anestrus, ewes in anestrus compare well to prepubertal ewes; another instance whereby $\mathrm{E}_{2}$ serves as the major inhibitor of $\mathrm{GnRH}$ and $\mathrm{LH}$ secretion.

\section{CONTROL OF REPRODUCTIVE CYCLICITY: MENSTRUAL CYCLES IN}

\section{PRIMATES}

In contrast to sheep, humans and nonhuman primates have menstrual cycles which last approximately 28 days and are characterized by sloughing of the endometrium (13). In humans, the menstrual cycle consists of a 14 day follicular phase and a 14 day luteal phase. Similar to the follicular phase that occurs during the estrous cycle, the follicular phase in the menstrual cycle is also responsible for producing an oocyte to be ovulated and that is capable of being fertilized (13). However, the follicular phase during the menstrual cycle is also a time during which the uterine endometrium undergoes estrogen-induced proliferation. The follicular phase is initiated 
once menstrual bleeding from the previous cycle begins, and the follicular phase ends when the mid-cycle LH surge occurs. During the early portions of the follicular phase, FSH and inhibin B concentrations are increased while LH, inhibin $\mathrm{A}, \mathrm{E}_{2}$ and progesterone concentrations remain low (13). As a female approaches the mid-cycle LH surge, $E_{2}$ and inhibin A concentrations increase while FSH concentrations decrease. This results in the emergence of a dominant follicle and aids in the proliferation of the uterine endometrium. Concurrently, LH concentrations remain relatively constant or increase gradually (13). The follicular phase ends when LH and FSH concentrations increase significantly, culminating in the rupture of the dominant follicle and release of the oocyte. As is expected, there is a decrease in $E_{2}$ and inhibin $B$ production from the follicle immediately after ovulation and progesterone begins to increase as the CL begins to form. This marks the beginning of the luteal phase (13). Progesterone aids in transitioning the endometrium from a proliferative to a secretory state in anticipation of implantation. In addition to secreting progesterone, the primate $\mathrm{CL}$ also secretes $\mathrm{E}_{2}$. If pregnancy does not occur, the lifespan of a human CL is 14-16 days (13). The CL will begin to regress when progesterone concentrations decrease. This results in menstruation and the beginning of a new menstrual cycle.

Studies by the Knobil lab in rhesus monkeys demonstrate that $\mathrm{E}_{2}$ is the principal regulator of the timing of the LH surge in primates. Estradiol concentrations must increase to approximately $275 \mathrm{pg} / \mathrm{ml}$ for 24-36 hours for an LH surge to be initiated (59). Thus, it appears there is a "pelvic clock" which is responsible for the timing of the LH surge in primates. In addition to timing the LH surge, $\mathrm{E}_{2}$ is also involved in the selection of a dominant follicle to be ovulated in primates (13). 
Similar to sheep, the GnRH pulse generator seems to be present within the MBH in primates. However, unlike in many species, the majority of GnRH neurons are found in the MBH lateral to the ARC surrounding the base of the third ventricle in primates (60). In the rhesus monkey, MUA can be recorded from the MBH. Additionally, when all neural inputs to the MBH are disrupted, pulsatile LH secretion is still observed indicating that the MBH alone contains the neuronal network responsible for generating GnRH, and thus LH, pulses (61). In support of this hypothesis, lesioning the ARC in OVX monkeys inhibits LH secretion (62). As is the case in sheep, kisspeptin neurons in the ARC are stimulators of GnRH and LH release $(47,63)$ and therefore may be responsible for GnRH pulse generation.

\section{NEUROENDOCRINE BASIS OF PUBERTAL DEVELOPMENT}

Puberty is the process whereby an individual acquires the ability to reproduce. Activation of the hypothalamic-adenohypophyseal-gonadal axis is one of the principal events that precedes reproductive maturation. In comparison to mature ewes in the follicular phase, the frequency of GnRH and LH release in prepubertal ewes is characteristically low (64). Administration of exogenous $E_{2}$ can induce a preovulatory-like surge of GnRH and LH release in prepubertal ewes as early as 12 weeks of age which is well before the normal time of puberty onset (65-67). However, the low frequency of GnRH and LH release characteristic of the prepubertal period cannot support the ovarian steroidogenic activity necessary to increase circulating concentrations of $E_{2}$ to concentrations that ultimately stimulate the preovulatory surge of GnRH and LH. As prepubertal ewes approach puberty, the frequency of GnRH release increases which in turn increases the frequency of LH release from the anterior pituitary. Increases in the frequency of 
LH release, in conjunction with the actions of FSH, promotes follicular maturation and $\mathrm{E}_{2}$ synthesis (64).

The lack of adequate stimulation of gonadotropes in the pituitary by GnRH is a critical limiting factor for the increased release of LH which is essential for reproductive maturity in female sheep. Giving immature ewes an hourly injection of LH for $48 \mathrm{~h}$ to mimic the rapid $\mathrm{LH}$ pulse frequency characteristic of the follicular phase in mature ewes induces an LH surge and ovulation (68). Therefore, once suitable gonadotropin stimulation is available, females can become reproductively active. However, without the aid of exogenous hormones, the lower frequency of LH release in prepubertal ewes is not sufficient to produce the significant increases in follicle size and estrogen production that are essential for initiating a GnRH and LH surge. This is because prepubertal ewes are exquisitely sensitive to the inhibitory effects of low concentrations of $\mathrm{E}_{2}$ (69).

As ewes approach the pubertal transition, sensitivity to $\mathrm{E}_{2}$ negative feedback decreases, resulting in an increase in the frequency of $\mathrm{LH}$ release $(70,71)$. This sensitivity to $\mathrm{E}_{2}$ negative feedback has been demonstrated in many studies utilizing prepubertal ewes. Administration of $\mathrm{E}_{2}$ via a Silastic implant decreases LH pulse frequency, but not amplitude, in prepubertal OVX ewes (72). Additionally, Foster et al. 1988 (73) used a technique whereby E2 implants were inserted for three weeks in prepubertal ewes, removed for a subsequent three weeks, and then an $\mathrm{E}_{2}$ implant was reinserted into the same animal three weeks later to demonstrate that sensitivity to $E_{2}$ negative feedback decreases as ewes approach puberty. Insertion of an $E_{2}$ implant consistently suppresses LH secretion until ewes are approximately 27 weeks of age, the time when intact ewes are normally ovulating for the first time. At 27 weeks of age, insertion of the 
same $E_{2}$ implant no longer decreased LH secretion in these ewes (73). Thus, the effectiveness of $\mathrm{E}_{2}$ to inhibit LH secretion is decreased as ewes approach puberty.

While it is clear that decreased sensitivity to $E_{2}$ negative feedback plays a critical role in the initiation of puberty in ewes, how this feedback is communicated to GnRH neurons remains to be determined. Gonadotropin-releasing hormone neurons do not contain ER $\alpha$, the estrogen receptor that is considered to be essential for estrogenic regulation of reproductive processes (26, 27). Therefore, neuronal intermediates that do contain ER $\alpha$ must exist to communicate this feedback to GnRH neurons to aid in controlling the onset of puberty.

\section{KISSPEPTIN}

Kisspeptin is one neuronal intermediate that appears to play an important role in communicating $\mathrm{E}_{2}$ negative feedback to $\mathrm{GnRH}$ neurons. The gene that encodes for kisspeptin, KISS1, was first discovered as a human malignant melanoma metastasis-suppressor gene with the ability to decrease the metastatic potential of malignant melanoma cells (74). The various isoforms of kisspeptin range from 10 to 54 amino acids and are derived from a 145-amino acid

precursor. All kisspeptins have a common carboxy terminal containing an arginine and amidated phenylalanine (RFamide) motif which is necessary for the activation of KISS1R (74-76). The 53-, 16-, 14-, 13- and 10-amino acid forms of kisspeptin are found in hypothalamic tissue, and all isoforms of kisspeptin bind to KISS1R with similar affinity (75).

In almost every mammalian species studied to date, the majority of kisspeptin neurons are located in two distinct brain regions: the POA and ARC (77-79). Depending on the species, the distribution of kisspeptin neurons in the POA and ARC varies. In the ARC, kisspeptin neurons are distributed in all rostral to caudal levels in mice (80) and rats (81). Kisspeptin neurons are 
also found in the rostral portions of the ARC in sheep and nonhuman primates. However, the majority of kisspeptin neurons are found in the middle and caudal levels of the ARC in these species $(40,60)$. In the POA of mice and rats, kisspeptin neurons are located directly adjacent to the third ventricle in the rostral periventricular area of the third ventricle (RP3V) (77, 80-82). In addition to being found close to the third ventricle as is observed in rodents, kisspeptin neurons in sheep are also present in a more dispersed manner in the medial POA $(39,40,78)$. This disperse distribution of kisspeptin neurons is also observed in the POA of nonhuman primates $(79,83)$ and humans $(84)$. In addition, kisspeptin neurons are found in the anterior portion of the bed nucleus of the stria terminalis (BNST) as well as the periventricular nucleus $(\mathrm{PeV})$ in nonhuman primates $(79,83)$. Depending on the area in which kisspeptin neurons are located, these neurons coexpress different classical neurotransmitters and neuropeptides. In the POA, subpopulations of kisspeptin neurons also synthesize GABA, dopamine, met-enkephalin, and galanin. In the POA of adult mice, $80 \%$ of kisspeptin neurons express galanin (85, 86), 70\% express glutamic acid decarboxylase-1 mRNA (the enzyme responsible for synthesizing GABA) (87), 50\% express tyrosine hydroxylase (the enzyme responsible for synthesizing catecholamines) (88), and 30\% express met-enkephalin (86). In the ARC, a high degree of colocalization is found between kisspeptin, NKB, and dynorphin (40, 89). As was discussed earlier, these neurons are commonly referred to as "KNDy" neurons. Kisspeptin neurons in the ARC also express the vesicular glutamate transporter, vGlut2, and therefore may also contain glutamate $(42,87,90)$.

Besides the kisspeptin populations located in the POA and ARC, kisspeptin neurons are found elsewhere in the brain including in the medial amygdala of mice and rats (91). Kisspeptin is also 
present in the placenta, pancreas, gonads, uterus, pituitary, and adipose tissue (75, 76, 92-95).

The function of kisspeptin in many of these tissues remains to be determined.

Kisspeptin was initially discovered to be critical for reproductive function and pubertal development by the observation that mutations in KISS1R lead to an absence of puberty, infertility, and hypogonadotropic hypogonadism in humans $(96,97)$ and mice (96). Subsequent studies established that kisspeptin acts as a critical regulator of the GnRH neuronal network (98). Kisspeptin potently stimulates LH secretion in several species studied to date (78, 99-103). When Kiss1r is knocked out in mice, high frequency LH secretion is absent even after gonadectomy (104). Kisspeptin can stimulate LH secretion by acting directly on GnRH neurons, since these neurons express KISS1R $(105,106)$, and kisspeptin-containing fibers have been observed directly apposed to GnRH neurons $(107,108)$. In rats, subcutaneous administration of kisspeptin results in the expression of c-Fos in $88 \%$ of GnRH neurons located in the organum vasculosum of the lamina terminalis (OVLT) (109). Administration of the GnRH receptor antagonist, acyline, inhibits the effects of kisspeptin on LH secretion in primates (103), and kisspeptin fails to induce LH secretion in hypothalamo-pituitary disconnected ewes (110) or ewes pretreated with GnRH antiserum $(103,111)$. Collectively, these findings illustrate that GnRH neurons are direct targets of kisspeptin. However, kisspeptin may also stimulate GnRH secretion through indirect pathways. Nitric oxide (NO), a gaseous neurotransmitter, has been implicated in the control of GnRH secretion (112-115), and administration of kisspeptin activates neuronal nitric oxide synthase (nNOS) neurons near the OVLT in mice by binding to KISS1R and stimulating NO release (112). Kisspeptin can also indirectly influence the activity of GnRH neurons through GABA and glutamate release $(116,117)$. Thus, whether it be through direct or indirect mechanisms, kisspeptin significantly influences GnRH and LH secretion. 
In addition to potently stimulating GnRH and LH secretion in adult animals, kisspeptin also plays a critical role in the initiation of puberty $(96,97,99,100)$. As mentioned above, mutations in KISS1 or KISS1R lead to an absence of puberty in humans and mice $(96,97,118,119)$. Administration of kisspeptin in prepubertal rats (99), sheep (101), and primates (100) increases LH secretion. Similarly, prepubertal mice given daily injections of a synthetic kisspeptin analog exhibit advanced pubertal onset (120). Thus, the neuronal circuitry connecting kisspeptin and GnRH neurons is capable of functioning prior to the initiation of puberty in many species. In sheep, the number of kisspeptin neurons in the ARC, as well as the percentage of GnRH neurons that exhibit kisspeptin close-contacts, increase as animals transition from a prepubertal to a postpubertal state (108). An increase in the number of neurons expressing Kiss1 mRNA in the middle ARC is also observed as LH pulse frequency increases in peripubertal OVX+E ewes (121). In rats, kisspeptin mRNA abundance increases postpubertally in both the ARC and anteroventral periventricular nucleus (AVPV) $(122,123)$. In monkeys, kisspeptin mRNA abundance is increased in the MBH of pubertal females when compared to juvenile females (103). Altogether, these studies demonstrate that kisspeptin is essential for the initiation of puberty.

One of the main ways kisspeptin may influence the timing of puberty onset and reproductive cyclicity in females is through the communication of steroid feedback. Sex steroids, particularly $\mathrm{E}_{2}$, clearly affect kisspeptin expression. Gonadectomy increases KISS1 mRNA in the ARC of adult mice $(124,125)$, and sheep (43). Kisspeptin receptor mRNA abundance also increases in the infundibular recess of postmenopausal women and OVX monkeys (126). In some species, similar observations have been noted in prepubertal animals. The number of kisspeptin neurons in the ARC was increased in OVX ewes compared to OVX prepubertal ewes given a 
subcutaneous 1-cm long $\mathrm{E}_{2}$ implant $(\mathrm{OVX}+\mathrm{E})$, whereas numbers were similar in $\mathrm{OVX}$ and $\mathrm{OVX}+\mathrm{E}$ postpubertal ewes. An increase in the number of kisspeptin neurons is also observed in OVX prepubertal ewes compared to intact prepubertal ewes (108). However, in nonhuman primates, the pubertal increase in KISS1 mRNA abundance appears to be independent of changes in steroid hormone concentrations (103). This may be due to the fact that menarche is not a steroid-dependent process in primates (13). Few changes in KISS1 mRNA abundance are also detected after ovariectomy in female nonhuman primates (127). In contrast to what is seen in the ARC, gonadectomy decreases the number of kisspeptin mRNA- or peptide-containing cells in the POA of adult rodents and sheep $(43,124,128)$. Because of this, it is hypothesized that the two kisspeptin populations serve different roles in the communication of $E_{2}$ feedback and the control of GnRH and LH secretion.

In mice and rats, kisspeptin neurons in the POA aid in communicating $\mathrm{E}_{2}$ positive feedback $(129,130)$ and have a key role in the generation of the GnRH and LH surge. When microimplants of $E_{2}$ are placed in the POA of rats, a GnRH and LH surge is observed (131). Kisspeptin mRNA abundance is at its highest level on the evening of proestrus in rats and remains elevated during the GnRH and LH surge. Kisspeptin neurons in the POA also coexpress c-Fos at the time of the surge in rats (132) and treatment with kisspeptin antiserum in the POA blocks the surge $(82,133)$. Because a high percentage of kisspeptin neurons in the POA of rodents contain $\mathrm{ER} \alpha, \mathrm{E}_{2}$ may act directly on these kisspeptin neurons to stimulate $\mathrm{GnRH}$ secretion (124).

In other species, the role of the POA populations of kisspeptin neurons in mediating $\mathrm{E}_{2}$ positive feedback and the GnRH/LH surge is less clear. Consistent with what is observed in rodent models, kisspeptin peptide and mRNA abundance increase in the POA of ewes in the late 
follicular phase (39, 51). However, in sheep (134) and nonhuman primates (135), $E_{2}$ acts in the MBH to induce a GnRH and LH surge. Kisspeptin mRNA abundance also increases in the caudal and middle ARC of ewes just prior to the surge (51). Additionally, the percentage of kisspeptin cells expressing c-Fos in both the POA and ARC increases during the surge in ewes (78). However, another research group found that c-Fos was only expressed in kisspeptin neurons in the POA, and not the ARC, after $\mathrm{E}_{2}$ treatment which mimicked the late follicular phase in ewes (136). Thus, it remains to be determined whether $E_{2}$ positive feedback in ewes is communicated solely through POA kisspeptin neurons or through both POA and ARC kisspeptin neurons.

In contrast to the role of POA neurons in the GnRH and LH surge, evidence for the role of kisspeptin neurons in the ARC in communicating $\mathrm{E}_{2}$ negative feedback is much less contentious with data supporting their involvement in mice $(128,137,138)$, rats $(139)$, sheep $(51,78)$, and nonhuman primates (140). When kisspeptin neurons are ablated in the ARC of rats, the expected increase in mean LH concentrations after ovariectomy is absent (141). When ewes are subjected to either short- or long-term $E_{2}$ withdrawal following ovariectomy, the percentage of kisspeptin cells expressing c-Fos increases in the ARC but not the POA (78). Combined with experiments illustrating that ovariectomy increases kisspeptin expression in the ARC of mice (124), sheep (43) and nonhuman primates (126), as well as the fact that a high percentage of ARC kisspeptin neurons contain ER $\alpha$ (39), it is plausible to expect that these kisspeptin neurons participate in the communication of $\mathrm{E}_{2}$ negative feedback to $\mathrm{GnRH}$ neurons. However, kisspeptin is unlikely to be the sole entity involved in communicating these effects to GnRH neurons. Other neuronal intermediates are likely involved and are discussed in subsequent sections of this review. 


\section{NEUROKININ B}

Neurokinin B is one potential intermediate besides kisspeptin that may also participate in the communication of $\mathrm{E}_{2}$ negative feedback to $\mathrm{GnRH}$ neurons and the control of puberty onset in sheep. Neurokinin B is a member of the tachykinin family of peptides which also includes substance P, neurokinin A, neuropeptide K, neuropeptide $\gamma$, and hemokinin-1 (142, 143). All tachykinins contain a common C-terminal amino acid sequence (Phe-X-Gly-Leu-Met-NH2), but NKB is the only tachykinin synthesized from the preprotachykinin-B gene $(142,143)$. As a note, the nomenclature for NKB depends upon which species is being referenced. In humans and nonhuman primates, NKB is referred to as TAC3. In rodents, NKB is referred to as TAC2, and in sheep the peptide is referred to as NKB (144).

To exert its effects, NKB preferentially binds to NK3R. Activation of NK3R results in an increase in intracellular calcium and cAMP concentrations (145). Once activated, NK3Rs are internalized within the cell, and, as such, NK3R internalization is often used as an indirect measure of receptor activity (146). Currently, two other tachykinin receptors have also been identified: NK1R and NK2R (147). All three tachykinin receptors are members of the rhodopsin-like family of G-protein-coupled receptors and exhibit substantial structural homology, leading to some promiscuity between tachykinin peptides and receptors (142). Nonetheless, substance P preferentially binds to NK1R, neurokinin A preferentially binds to NK2R, and NKB preferentially binds to NK3R (147).

In sheep, the majority of NKB neurons are located in the ARC $(33,48)$. NKB neurons also likely reside in other areas of the brain and hypothalamus of sheep because NKB fibers that do not contain kisspeptin or dynorphin are observed outside of the ARC (48). Neurokinin B neurons are also found in the ARC of monkeys $(148,149)$, goats $(53)$, mice $(150,151)$, and rats 
(152-155). In addition to the ARC NKB neuronal population, cells expressing NKB mRNA are found elsewhere in the AHA, septal region, DBB, nucleus basalis of Meynert, BNST, and amygdala of humans (156). In the rat, small numbers of NKB neurons are also found in the AHA, lateral hypothalamic area (LHA), dorsomedial hypothalamus (DMH), POA, BNST, amygdala, septal nuclei, nucleus accumbens, and DBB (152-155).

While the majority of NKB neurons are located in the ARC, large numbers of NK3R neurons are found in several areas of the brain and hypothalamus. In sheep, NK3R neurons are present in the paraventricular nucleus (PVN), ARC, premammillary region, POA, retrochiasmatic area (RCh), BNST, and DMH (52). In rats, NK3R neurons are located in the zona incerta (ZI), ARC, POA, LHA, perifornical region (PFO), PVN, supraoptic nucleus (SON), septal nuclei, DBB, nucleus basalis, AHA, DMH, and mammillary nuclei $(157,158)$.

It was first hypothesized that NKB may play a role in reproduction when it was found that NKB mRNA abundance increased, and neurons containing NKB hypertrophied, in the infundibular nucleus of postmenopausal women (159). Because menopause is characterized by increased gonadotropin secretion due to decreased $E_{2}$ negative feedback (160), it was postulated that NKB neurons may play an important role in the communication of $E_{2}$ negative feedback to GnRH neurons. Similar results of increased NKB mRNA abundance were reported in a primate model of menopause (161) as well as in OVX rats (162). However, these studies and the role of NKB in reproduction remained largely ignored until it was discovered that, similar to kisspeptin, mutations in TAC3 or TAC3R in humans leads to hypogonadotropic hypogonadism and infertility (163). The gonadotropin deficiency present in these individuals appears to result from an issue in NK3R signaling at the level of the hypothalamus, since pulsatile administration of GnRH can restore LH secretion and even resulted in ovulation, pregnancy and a normal birth in a female 
with a TAC3 mutation (164). Neurokinin B fibers contact 39\% of GnRH neurons in the POA and 23\% of GnRH neurons in the AHA of sheep (33), and NKB fibers contact GnRH axons in the median eminence of rats $(152,157,165)$. However, the effects of NKB on GnRH secretion mostly occur through indirect mechanisms because NK3R is not found in GnRH neurons or fibers in sheep (52), and only 16\% of GnRH neurons in the rat contain NK3R (157). In addition, NKB or the NK3R agonist, senktide, have no effect on GnRH neuron excitability in brain slices from male mice (166). Instead, NKB most likely influences GnRH secretion by acting on neurons present in the ARC, since NK3R is found in a high percentage of both NKB (i.e., KNDy) and non-NKB neurons in the ARC of rats (165), mice (151), and luteal phase ewes (52).

Functional studies in which NKB or NK3R agonists are administered result in various effects which depend upon the gonadal status of the animals and the species in which the experiments are conducted. In most species, administration of NKB or senktide stimulates an increase in LH secretion $(53,148,167,168)$. However, some of the first studies analyzing the role of NKB in the secretion of LH were conducted in rodents and resulted in conflicting reports on the effects of senktide. In one study, senktide injection into the lateral ventricle of OVX rats decreased LH concentrations (149). Similar results were seen with senktide administration in OVX mice (151). In contrast, when senktide is given to rats in either the diestrous or proestrous stage of the estrous cycle, LH secretion is increased (169). However, to further complicate the senktide narrative in rodents, Kinsey-Jones et al. (170) found that ICV administration of senktide suppressed LH secretion in OVX and OVX+E rats. Therefore, it is difficult to definitively conclude the effects of NKB and senktide administration on LH secretion in rodents. This story is less complicated in other species. Injection of NKB ICV in OVX goats induced MUA volleys (53). Senktide administration increases LH secretion in ovary-intact prepubertal and pubertal female monkeys 
(168) as well as gonadectomized prepubertal male monkeys (148). In sheep, senktide stimulates LH secretion in follicular phase ewes (167) and prepubertal ewes (108). Studies placing senktide within specific areas of the hypothalamus in adult sheep showed either a tonic- or surge-like increase in LH secretion (171). More specifically, placement of microimplants containing senktide into either the RCh or POA induces a surge-like increase in LH secretion, whereas senktide placement in the ARC prompts a more tonic-like increase in LH secretion (171). Therefore, with the exception of mice and rats, NKB stimulates LH secretion.

While it is clear that NKB influences GnRH and LH secretion, its role in the initiation of puberty is not as well characterized. Mutations in either TAC3 or TAC3R lead to hypogonadotropic hypogonadism in humans (163). However, some hypogonadotropic adolescent patients with NKB pathway mutations eventually exhibit activation of the hypothalamic-pituitary-gonadal axis as adults (172). This reversal indicates the NKB signaling pathway may be important for the timing of sexual development but may not be as critical for adult reproductive function. Similar results are observed in mice where $\mathrm{Tac}^{-/-}$females exhibit delayed time to vaginal opening and first estrus but recover cyclicity as adults (173). Administration of senktide increases LH secretion in prepubertal sheep (108) and monkeys (148, 168). Furthermore, chronic ICV administration of an NK3R antagonist, SB222200, for 14 days delays time to vaginal opening and first estrus in rats (174). Similar to kisspeptin, NKB expression is also affected by the presence of $\mathrm{E}_{2}(108,175)$, and a high percentage of NKB neurons contain ER $\alpha$ (176). Therefore, NKB may play a role in communicating $E_{2}$ negative feedback to GnRH neurons. In mice, NKB mRNA abundance is decreased in the ARC in the presence of $E_{2}$ in prepubertal and postpubertal females but does not change as females transition from a prepubertal to a postpubertal state (151). In another study, moderate increases in the 
number of neurons expressing NKB mRNA is observed from postnatal days 15-30 in mice (177). In sheep, the number of NKB neurons is decreased in the ARC in the presence of $E_{2}$ in both prepubertal and postpubertal ewes, but the number of NKB neurons does not change as these ewes transition from a prepubertal to a postpubertal state (108). Thus, while the number of NKB neurons may not change drastically from a prepubertal to a postpubertal state, NKB may function in some manner to influence sexual maturation.

\section{DYNORPHIN}

Dynorphin is the third member of the KNDy peptides which also influences reproductive cyclicity and the initiation of puberty in females. In addition to participating in the regulation of reproduction, dynorphin also functions to control behavioral, perceptual, reward, mood, and neuroendocrine processes, including food intake, water homeostasis, lactation, and stress (178182). There are several types of dynorphins, dynorphin $A_{1-17}$, dynorphin $A_{1-13}$, dynorphin $A_{1-8}$ and dynorphin B, which are derived from the preprodynorphin (PPD) gene (183). Dynorphins are members of the endogenous opioid family of peptides (EOPs) which also includes enkephalins and endorphins. Enkephalins and endorphins preferentially bind to delta and mu receptors, respectively, while dynorphins preferentially bind to KORs (184). All opioid receptors belong to the class $A$ rhodopsin family of $G_{i} / G_{0}$ protein-coupled receptors (185) and share $60 \%$ homology. Most similarities occur in the transmembrane helices, including two conserved cysteine residues in the first and second extracellular loops, whereas the greatest diversity in opioid receptors occurs in the $\mathrm{N}$ and $\mathrm{C}$ termini and extracellular loops (186).

Dynorphin was first identified in the pituitary (187-189) and has subsequently been found to be present throughout the central nervous system (190-193). In the rat, a high number of 
dynorphin neurons are present in the posterior pituitary, hypothalamus, medulla-pons, midbrain, and spinal cord (190). In sheep, neurons containing PPD mRNA and dynorphin A immunoreactivity were identified in the SON, PVN, POA, AHA, BNST, DMH, and ARC (193). In the ventromedial nucleus (VMN), PPD mRNA, but not dynorphin A, immunoreactivity was observed indicating that the PPD gene may be processed into another peptide product in this particular area (193).

Like dynorphin, KORs are widely distributed throughout the central nervous system. In humans, KOR mRNA is abundantly expressed in the striatum, thalamus, hypothalamus, cerebral cortex and cerebellum as well as in several locations in the brain stem and spinal cord (194). Kappa opioid receptor is not as widely distributed in rodents, but can still be found in the claustrum, endopiriform nucleus, nucleus accumbens, olfactory tubercle, amygdala, median eminence, infundibulum, substantia nigra, ventral tegmental area, raphe nuclei, paratrigeminal and spinal trigeminal, nucleus of the solitary tract, spinal cord and dorsal root ganglia (195). Specifically, in the hypothalamus of rats and sheep, KOR neurons are found in the SON, PVN, POA, AHA, ARC, VMH, DMH and premammillary nucleus (196).

Before researchers began to focus on the individual role of dynorphin in the control of reproduction, the actions of EOPs as a whole were analyzed. After the initial discovery of EOPs, several early studies in women indicated that these peptides might participate in communicating steroid negative feedback to GnRH neurons. Infusion of naloxone, a nonspecific opioid receptor antagonist, increases LH concentrations in women in the late follicular phase and luteal phase of the menstrual cycle (197). In addition, infusion of naloxone also increases LH concentrations in women given steroid replacement therapy (198), but naloxone does not increase LH concentrations in women in which the inhibitory effects of sex steroids are absent (199). In 
monkeys, EOPs seem to be important for mediating progesterone negative feedback but not $\mathrm{E}_{2}$ negative feedback. This is supported by evidence that naloxone increases LH concentrations significantly in monkeys during the luteal phase of the menstrual cycle but has no effect on LH concentrations in monkeys during the follicular phase (200).

In sheep, several experiments support a role for EOPs in the communication of steroid negative feedback. Administration of the long-acting opioid antagonist, WIN 44,443-1, increases LH pulse amplitude in OVX+E and follicular phase ewes, and increases LH pulse frequency in $\mathrm{OVX}+\mathrm{E}, \mathrm{OVX}+\mathrm{P}+\mathrm{E}$ and luteal phase ewes (201). Similar results are observed in breeding season and non-breeding season OVX ewes when treated with progesterone. However, there was a lack of an effect on LH secretion when these animals were treated with $\mathrm{E}_{2}$ alone (202). These results combined with the fact that naloxone similarly increases GnRH pulse amplitude in OVX and OVX+E ewes indicate EOPs may not be critical for communicating $\mathrm{E}_{2}$ negative feedback in adult ewes (56).

In addition to their importance in communicating progesterone negative feedback, EOPs may also play a role in the timing of the GnRH and LH surge. Infusion of naloxone during the late follicular phase of the menstrual cycle increases LH secretion in women (197). Similarly, in rats, infusion of naloxone enhances the LH surge (203). Furthermore, administration of a $\mu-$, but not $\kappa$ - or $\delta$-, opioid receptor agonist inhibits GnRH secretion and can block the estrogen-induced GnRH and LH surge in OVX ewes (204). Therefore, it appeared the $\beta$-endorphin/ $\mu$-receptor system controlled the timing of the GnRH and LH surge, but whether the opioid system mediated progesterone-negative feedback was still in question.

The use of specific $\mu-, \delta$-, and $\kappa$-opioid receptor antagonists in luteal phase ewes revealed $\kappa-$, but not $\mu$ - or $\delta$-, opioid receptors mediate the inhibition of LH secretion in the MBH (205). In 
addition, $90 \%$ of MBH GnRH neurons and $40-50 \%$ of GnRH neurons located elsewhere in the POA and AHA exhibit close associations with dynorphin-containing varicosities (205), and progesterone treatment increases dynorphin A concentrations in cerebrospinal fluid (CSF) (206). These data, combined with the knowledge that $90 \%$ of dynorphin neurons in the ARC of adult ewes contain progesterone receptors, indicates that dynorphin could be the EOP responsible for mediating progesterone negative feedback in ewes.

In species other than sheep, dynorphin also serves to inhibit LH secretion. In rats, administration of the KOR antagonist, nor-BNI, increases LH secretion in OVX females treated with low concentrations of $E_{2}$ but has no effect on OVX females without $E_{2}$ replacement (207). Similarly, administration of the selective KOR agonist, U50488, into the ARC of OVX+E rats results in a dose-dependent decrease in LH pulse frequency (208). In brain slices from male mice, treatment with dynorphin reduces spontaneous KNDy neuron activity and has a stronger inhibitory effect in intact versus castrate animals (209). Additionally, treatment with a KOR antagonist did not induce firing activity in quiescent KNDy neurons, suggesting that dynorphin may be important for terminating LH pulses more so than contributing to a constant inhibition on LH secretion in this species (209). Nonetheless, at least in mice and rats, the preponderance of evidence suggests dynorphin plays a role in mediating $E_{2}$ negative feedback.

The role of dynorphin in the initiation of puberty has not been well characterized. In female rats, chronic peripheral administration of nor-BNI advances vaginal opening and time to first estrus (210). Moreover, nor-BNI significantly increases LH pulse frequency in 29-day-old rats (210). In another study in immature female rats, injection of anti-dynorphin antibodies into the ARC increased LH concentrations (211). In prepubertal sheep, GnRH neurons in the POA colocalize with KOR, and infusion of nor-BNI into the lateral ventricle increases LH secretion in 
prepubertal, but not postpubertal, ewes (212). Therefore, in sheep and rats, dynorphin/KOR signaling seems to play a role in the prepubertal restraint of GnRH and LH secretion.

\section{NITRIC OXIDE/NEURONAL NITRIC OXIDE SYNTHASE}

In comparison to kisspeptin, $\mathrm{NKB}$, and dynorphin, the actions of $\mathrm{NO}$ on the initiation of puberty in sheep are grossly understudied. Nitric oxide was initially recognized as a messenger molecule in the CNS when it was classified as the intercellular factor that mediated increases in cyclic GMP (cGMP) concentrations following activation of the N-methyl-D-aspartate (NMDA) form of glutamate receptors $(213,214)$. Because NO is a gaseous neurotransmitter that freely diffuses in both hydrophobic and hydrophilic environments, it has the potential to influence countless cells and tissue types that don't necessarily have to be close to a NO-producing cell. Nitric oxide is produced by the enzyme, nitric oxide synthase (NOS) (215). Three isoforms of NOS exist: neuronal (nNOS), endothelial (eNOS), and inducible (iNOS). These isoforms are homologous, but their structure, regulation and distribution within the body vary.

As its name would suggest, nNOS was first discovered in the brain, is normally found in neurons, and is translated from the NOS1 gene located on chromosome 12 in humans $(216,217)$. Within the brain, nNOS neurons are found in the cortex, cerebellum, and hypothalamus as well as in several other areas (218-220). In the hypothalamus, nNOS neurons are present in the POA, SON, SFO, PVN, LHA, VMH, ARC, and ventral premammillary nucleus $(217,221,222)$. This localization allows for nNOS neurons to participate in the regulation of temperature, thirst, fluid balance, stress, glucose homeostasis, feeding, energy expenditure, and reproduction (223-232). The most common isoform of $\mathrm{nNOS}$ is the $150 \mathrm{kDa}$ protein, $\mathrm{nNOS} \alpha$ (217). This particular 
isoform accounts for $95 \%$ of all nNOS catalytic activity. However, two other splice variants exist: $\mathrm{nNOS} \beta$ and $\mathrm{nNOS} \gamma$.

Endothelial NOS is translated from the NOS3 gene located on chromosome 7 in humans (233). Endothelial NOS is found in the vascular endothelium throughout the body and is therefore involved in the regulation of vascular tone, cellular proliferation, leukocyte adhesion, and platelet aggregation (234). While nNOS is the most common form of NOS found within the brain, eNOS is also expressed in the brain $(222,235,236)$. Of particular importance to the control of reproduction, eNOS is located in vascular endothelial cells in the external zone of the median eminence, and could therefore influence the control of GnRH secretion into pituitary portal blood vessels (237).

The remaining isoform of NOS is iNOS. Inducible NOS is translated from the NOS2 gene that is located on chromosome 17 in humans (238). In contrast to eNOS and nNOS, iNOS can function independently of calcium because it has calmodulin as a subunit (239). Thus, iNOS is permanently activated and can produce NO for extended periods of time. Inducible NOS is primarily involved in inflammatory responses within the body and is expressed in macrophages, chondrocytes, Kupffer cells, hepatocytes and neutrophils, among other cell types (240). Because nNOS is the most common NOS isoform found in the brain, the remainder of this review will focus mostly on this isoform.

Intracellularly, NOS synthesizes NO through a reaction that converts L-arginine and oxygen to L-citrulline and NO (217). Neuronal NOS is activated when glutamate binds to NMDA receptors (NMDAR), resulting in an influx of calcium through the now open NMDAR channel (214). Increased intracellular calcium promotes calcium binding to calmodulin which forms a necessary cofactor essential for constitutive NOS activity (241). Once NO is produced, it 
diffuses to nearby cells to affect specific molecular targets. To regulate protein activity, NO reversibly binds to available heme iron and thiols (242). Nitric oxide most commonly binds to the heme moiety of guanylyl cyclase thereby activating the enzyme. Guanylyl cyclase subsequently catalyzes the production of cyclic GMP (cGMP) which results in an intracellular signaling cascade (243). To enhance nNOS activity, protein kinase B (AKT) phosphorylates a serine within the nNOS amino acid sequence (Ser1412). Neuronal NOS will remain activated until dephosphorylation occurs which is dependent upon $\alpha$-amino-3-hydroxy-5-methyl-4isoxazolepropionic acid (AMPA) receptors and L-type calcium channels $(244,245)$. In contrast to Ser1412 phosphorylation, phosphorylation of nNOS at Ser847 by calcium/calmodulindependent protein kinase type II (CaMKII) decreases NO production by 50\% (246, 247).

For decades, NO has been identified as a molecule which exhibits an influential role on GnRH and LH secretion by controlling estrous cyclicity and mediating the onset of the GnRH surge (112, 248-253). Huang et al. (254) used homologous recombination to generate the first line of mice lacking the nNOS gene. These mutant mice were without exon 2 of the Nos1 gene and did not exhibit any reproductive deficits. However, even with deletion of exon 2 of the Nos1 gene, alternatively spliced isoforms, $\mathrm{nNOS} \beta$ and $\mathrm{nNOS} \gamma$, were still present and active (255). It was hypothesized that this residual activity may have resulted in the mild deficits observed in these mutant mice. When exon 6 , the exon which encodes the catalytic heme-binding domain of all nNOS variants, is instead deleted from the Nos1 gene, mice do not produce litters and display hypogonadotropic hypogonadism (256). Deficits in these mutant mice appear to be central in nature because ovaries from mutant mice ovulate normally when transplanted into wild type mice and wild type ovaries have decreased ovulation rates when transplanted into mutant mice 
(256). Therefore, nNOS signaling does participate in the neuroendocrine control of reproductive function.

Because a high density of nNOS-containing neurons and fibers are found in the vicinity of GnRH neurons, a neuroanatomical relationship may exist between nNOS and GnRH (257). In adult mice and rats, nNOS and GnRH do not colocalize in the same neurons in the POA (114, 257). However, NO can influence the electrical activity of GnRH neurons. Administration of the NO precursor, L-arginine, or the NO donor, diethylamine/NO, during patch clamp recordings of GnRH neurons reduces the spontaneous firing activity of these neurons (114). Treatment with a NOS inhibitor prevented this reduction in firing activity, but uncoupling synaptic transmission did not inhibit the effects of NO, indicating NO affects GnRH neuronal activity by acting at a postsynaptic site (114). Therefore, NO may facilitate the synchronous activity of GnRH neurons which is essential for the bursting activity of GnRH neurons required for the GnRH surge and ovulation. In addition to directly acting on GnRH neurons to influence neuronal activity and GnRH secretion, NO may also indirectly regulate GnRH secretion through kisspeptin neurons. In mice, nNOS neurons in the POA, but not the MBH, are associated with kisspeptin fibers and express KISS1R (112). Treatment with kisspeptin also leads to the phosphorylation of Ser1412 of nNOS in the POA (112). Thus, it appears nNOS may act both directly and indirectly to influence GnRH and LH secretion.

Pharmacological studies have also indicated NO participates in the control of GnRH and LH secretion. In castrated male rats, injection of a NOS inhibitor into the third ventricle inhibited pulsatile LH release and decreased plasma LH concentrations (249). In OVX ewes, injection of a NOS inhibitor into the third ventricle also decreases mean LH concentrations and LH pulsatility (258). During anestrus, NOS inhibitors administered in the POA have mostly modest 
and inconsistent effects on LH secretion with some inhibitors increasing LH secretion while others have no effect (259). However, NOS inhibitors never decreased LH secretion, indicating NO most likely acts as an inhibitor of LH secretion in anestrous ewes. In female mice, intraperitoneal injection of a NOS inhibitor increased LH release when given during the diestrous phase of the estrous cycle. In contrast, injection of this inhibitor blocked the LH surge (112). Therefore, NO appears to inhibit LH secretion under steroid negative feedback conditions but stimulates LH secretion during steroid positive feedback conditions.

Because changes to the NO system occur throughout the estrous cycle and $\mathrm{E}_{2}$ modulates NO signaling and expression $(112,113,115)$, NO may be involved in communicating $\mathrm{E}_{2}$ feedback to GnRH neurons. In rats, nNOS interacts with the NR2B subunit of glutamate NMDA receptors via the scaffolding protein, postsynaptic density-95 (PSD-95). At the onset of the GnRH and LH surge, increased nNOS/NR2B complex formation occurs compared to that observed during diestrus (115). Treatment of OVX rats with $\mathrm{E}_{2}$ also increases nNOS/NR2B complex formation. The association of nNOS with PSD-95 also fluctuates throughout the estrous cycle with the greatest amount of interaction occurring when $E_{2}$ concentrations are increased (115). In addition to maximal complex formation between nNOS and NR2B and nNOS and PSD-95 when $\mathrm{E}_{2}$ concentrations are elevated, phosphorylation of nNOS at Ser1412 in the POA peaks on the afternoon of proestrus (113). Collectively, these data demonstrate $E_{2}$ directly affects nNOS neurons in the POA, and NO production is associated with glutamate, a known participant in the communication of $E_{2}$ positive feedback to GnRH neurons $(260,261)$. Thus, NO may aid in controlling the onset of the GnRH and LH surge. The fact that nNOS neurons in mice $(262,263)$ and rats (264) contain ER $\alpha$ also suggests that nNOS neurons could participate in communicating $\mathrm{E}_{2}$ feedback. 
In addition to participating in the communication of $\mathrm{E}_{2}$ feedback and influencing pulsatile $\mathrm{LH}$ secretion, several in vitro and in vivo studies have implicated NO in the control of the GnRH and LH surge. In vitro, treating hypothalamic explants or GT1 cells with the NO donor, sodium nitroprusside, stimulates LH secretion in a dose-dependent manner and is associated with increased extracellular and intracellular cGMP concentrations (248). In vivo, concentrations of cGMP in the POA increase on the afternoon of proestrus and diestrus II in female rats as well as in OVX rats and OVX rats treated with ovarian steroids to induce an LH surge (252). Injection of a selective inhibitor of soluble guanylate cyclase also suppresses the LH surge (252). When antisense oligonucleotides of nNOS or eNOS are injected into the third ventricle of steroidprimed OVX rats, the LH surge is significantly attenuated (251). Similarly, subcutaneous injections of three NOS inhibitors significantly reduced the LH surge in steroid-primed OVX rats (250).

While there is a plethora of evidence to support the notion that NO is involved in the control of GnRH and LH secretion in adult animals, very few studies have analyzed the involvement of NO in the regulation of the reproductive neuroendocrine axis prior to the onset of puberty. When female rats are treated with a NOS inhibitor through administration in drinking water, puberty onset is delayed (265). In mice, the first activation of the reproductive neuroendocrine axis occurs during the infantile period when mice are approximately two weeks of age and is referred to as "mini puberty" (266). At this time, kisspeptin, as well as other neuronal fiber projections from the ARC, arrive in the POA $(267,268)$. Neuronal NOS activity also increases in the second week of life and therefore may be involved in activation of the reproductive axis during mini puberty $(267,269)$. Nitric oxide may also aid in communicating metabolic signals which are critical for the initiation of puberty. Neuronal NOS neurons in the POA of mice are 
activated after leptin injection, and either deletion of the nNOS gene or pharmacological blockade of NOS activity in the POA decreases the ability of leptin to stimulate LH secretion (270). Pharmacological blockade of NOS in peripubertal and prepubertal female rats also inhibits leptin-induced GnRH and LH secretion (271). Altogether, it is possible that NO may play a role in relaying both reproductive and metabolic signals necessary for the initiation of puberty in rodents. The actions of NO in the initiation of puberty in species besides mice and rats has yet to be examined.

\section{SPECIFIC AIMS}

As reviewed above, NKB, dynorphin, and NO appear to influence reproduction in various mammalian species. However, the participation of each of these neurotransmitters in the initiation of puberty in sheep, as well as the role of $\mathrm{NO} / \mathrm{nNOS}$ in the control of reproductive cyclicity in adult animals, is not well characterized. Therefore, we propose three specific aims to further elucidate the role of $\mathrm{NKB}$, dynorphin, and $\mathrm{NO} / \mathrm{nNOS}$ in the initiation of puberty and control of reproductive cyclicity.

Specific Aim 1: To determine where NKB and dynorphin act in the hypothalamus of prepubertal sheep to influence LH secretion, we used intrahypothalamic placement of an NK3R agonist or KOR antagonist into the ARC or POA of prepubertal ewes. Additionally, we examined whether changes in NK3R expression occurred as a result of an escape from $E_{2}$ negative feedback or maturation. Finally, we determined if maturation from a prepubertal to a postpubertal state influenced the percentage of GnRH neurons expressing KOR. 
Specific Aim 2: To characterize nNOS expression in the hypothalamus of prepubertal sheep, we evaluated the distribution of nNOS neurons in the POA and hypothalamus. Furthermore, we determined whether nNOS neurons expressed $\mathrm{ER} \alpha$ as well as if a neuroanatomical relationship existed between nNOS and kisspeptin and nNOS and GnRH neurons. We also investigated whether the presence or absence of $\mathrm{E}_{2}$ had any effect on these relationships.

Specific Aim 3: To examine the neuroanatomical relationship between nNOS and kisspeptin and nNOS and GnRH in adult female sheep and nonhuman primates, we compared the percent colocalization and number of close-contacts between these neuronal populations in these two species. Additionally, we investigated if these relationships were influenced by the phase of the estrous cycle in sheep or the menstrual cycle in nonhuman primates. 


\section{REFERENCES}

1. McKenzie F, Terrill C. Estrus, ovulation, and related phenomena in the ewe. Columbia, Missouri: University of Missouri, College of Agriculture, Agricultural Experiment Station, 1937.

2. Chaffin CL, Vandevoort CA. Follicle growth, ovulation, and luteal formation in primates and rodents: a comparative perspective. Exp Biol Med (Maywood) 2013; 5: 539-548.

3. Long JA, Evans HM. The oestrous cycle in the rat and its associated phenomena. Berkeley, Calif. : University of California Press, 1922.

4. Goodman RL. Neuroendocrine Control of Gonadotropin Secretion: Comparative Aspects. In: Plant TM and Zeleznik AJ, eds. Knobil and Neill's Physiology of Reproduction. London: Elsevier, 2015: 1537-1574.

5. Goodman RL, Inskeep EK. Control of the Ovarian Cycle of the Sheep. In: Plant TM and Zeleznik AJ, eds. Knobil and Neill's Physiology of Reproduction. London: Elsevier, 2015: 12591305.

6. Moenter SM, Caraty A, Locatelli A, Karsch FJ. Pattern of gonadotropin-releasing hormone $(\mathrm{GnRH})$ secretion leading up to ovulation in the ewe: existence of a preovulatory GnRH surge. Endocrinology 1991; 3: 1175-1182.

7. Moenter SM, Brand RC, Karsch FJ. Dynamics of gonadotropin-releasing hormone (GnRH) secretion during the GnRH surge: insights into the mechanism of GnRH surge induction. Endocrinology 1992; 5: 2978-2984. 
8. Hauger RL, Karsch FJ, Foster DL. A new concept for control of the estrous cycle of the ewe based on the temporal relationships between luteinizing hormone, estradiol and progesterone in peripheral serum and evidence that progesterone inhibits tonic LH secretion. Endocrinology 1977; 3: 807-817.

9. Davies KL, Bartlewski PM, Pierson RA, Rawlings NC. Computer assisted image analyses of corpora lutea in relation to peripheral concentrations of progesterone: a comparison between breeds of sheep with different ovulation rates. Anim Reprod Sci 2006; 1-2: 165-175.

10. Goodman RL, Pickover SM, Karsch FJ. Ovarian feedback control of follicle-stimulating hormone in the ewe: evidence for selective suppression. Endocrinology 1981; 3: 772-777.

11. Baird DT, Land RB, Scaramuzzi RJ, Wheeler AG. Endocrine changes associated with luteal regression in the ewe; the secretion of ovarian oestradiol, progesterone and androstenedione and uterine prostaglandin F2alpha throughout the oestrous cycle. J Endocrinol 1976; 2: 275-286.

12. Levine JE. Neuroendocrine Control of the Ovarian Cycle of the Rat. In: Plant TM and Zeleznik A, eds. Knobil and Neill's Physiology of Reproduction. London: Elsevier, 2015: 11991257.

13. Zeleznik A, Plant T. Control of the Menstrual Cycle. In: Zeleznik A and Plant T, eds. Knobil and Neill's Physiology of Reproduction, 2015: 1307-1348.

14. Murdoch WJ, Murphy CJ, Van Kirk EA, Shen Y. Mechanisms and pathobiology of ovulation. Soc Reprod Fertil Suppl 2010; : 189-201. 
15. Baird DT, Scaramuzzi RJ. Changes in the secretion of ovarian steroid and pituitary luteinizing hormone in the peri-ovulatory period in the ewe: the effect of progesterone. $\mathrm{J}$ Endocrinol 1976; 2: 237-245.

16. Goodman RL, Gibson M, Skinner DC, Lehman MN. Neuroendocrine control of pulsatile GnRH secretion during the ovarian cycle: evidence from the ewe. Reprod Suppl 2002; : 41-56.

17. Evans AC. Ovarian follicle growth and consequences for fertility in sheep. Anim Reprod Sci 2003; 3-4: 289-306.

18. Bartlewski PM, Beard AP, Cook SJ, Chandolia RK, Honaramooz A, Rawlings NC. Ovarian antral follicular dynamics and their relationships with endocrine variables throughout the oestrous cycle in breeds of sheep differing in prolificacy. J Reprod Fertil 1999; 1: 111-124.

19. Johnson SK, Dailey RA, Inskeep EK, Lewis PE. Effect of peripheral concentrations of progesterone on follicular growth and fertility in ewes. Domest Anim Endocrinol 1996; 1: 69-79.

20. Souza CJ, Campbell BK, Webb R, Baird DT. Secretion of inhibin A and follicular dynamics throughout the estrous cycle in the sheep with and without the Booroola gene (FecB). Endocrinology 1997; 12: 5333-5340.

21. Souza CJ, Campbell BK, Baird DT. Follicular waves and concentrations of steroids and inhibin A in ovarian venous blood during the luteal phase of the oestrous cycle in ewes with an ovarian autotransplant. J Endocrinol 1998; 3: 563-572.

22. Toosi BM, Seekallu SV, Barrett DM, Davies KL, Duggavathi R, Bagu ET, Rawlings NC. Characteristics of peaks in serum concentrations of follicle-stimulating hormone and estradiol, 
and follicular wave dynamics during the interovulatory interval in cyclic ewes. Theriogenology 2010; 9: 1192-1201.

23. Lehman MN, Robinson JE, Karsch FJ, Silverman AJ. Immunocytochemical localization of luteinizing hormone-releasing hormone (LHRH) pathways in the sheep brain during anestrus and the mid-luteal phase of the estrous cycle. J Comp Neurol 1986; 1: 19-35.

24. Jansen HT, Hileman SM, Lubbers LS, Kuehl DE, Jackson GL, Lehman MN. Identification and distribution of neuroendocrine gonadotropin-releasing hormone neurons in the ewe. Biol Reprod 1997; 3: 655-662.

25. Skinner DC, Caraty A, Allingham R. Unmasking the progesterone receptor in the preoptic area and hypothalamus of the ewe: no colocalization with gonadotropin-releasing neurons. Endocrinology 2001; 2: 573-579.

26. Lehman MN, Karsch FJ. Do gonadotropin-releasing hormone, tyrosine hydroxylase-, and beta-endorphin-immunoreactive neurons contain estrogen receptors? A double-label immunocytochemical study in the Suffolk ewe. Endocrinology 1993; 2: 887-895.

27. Herbison AE, Robinson JE, Skinner DC. Distribution of estrogen receptor-immunoreactive cells in the preoptic area of the ewe: co-localization with glutamic acid decarboxylase but not luteinizing hormone-releasing hormone. Neuroendocrinology 1993; 4: 751-759.

28. Skinner DC, Herbison AE. Effects of photoperiod on estrogen receptor, tyrosine hydroxylase, neuropeptide $\mathrm{Y}$, and beta-endorphin immunoreactivity in the ewe hypothalamus. Endocrinology 1997; 6: 2585-2595. 
29. Pompolo S, Pereira A, Scott CJ, Fujiyma F, Clarke IJ. Evidence for estrogenic regulation of gonadotropin-releasing hormone neurons by glutamatergic neurons in the ewe brain: An immunohistochemical study using an antibody against vesicular glutamate transporter-2. J Comp Neurol 2003; 1: 136-144.

30. Scott CJ, Rawson JA, Pereira AM, Clarke IJ. Oestrogen receptors in the brainstem of the female sheep: relationship to noradrenergic cells and cells projecting to the medial preoptic area. J Neuroendocrinol 1999; 10: 745-755.

31. Simonian SX, Delaleu B, Caraty A, Herbison AE. Estrogen receptor expression in brainstem noradrenergic neurons of the sheep. Neuroendocrinology 1998; 6: 392-402.

32. Foradori CD, Coolen LM, Fitzgerald ME, Skinner DC, Goodman RL, Lehman MN. Colocalization of progesterone receptors in parvicellular dynorphin neurons of the ovine preoptic area and hypothalamus. Endocrinology 2002; 11: 4366-4374.

33. Goubillon ML, Forsdike RA, Robinson JE, Ciofi P, Caraty A, Herbison AE. Identification of neurokinin B-expressing neurons as an highly estrogen-receptive, sexually dimorphic cell group in the ovine arcuate nucleus. Endocrinology 2000; 11: 4218-4225.

34. Scanlan N, Dufourny L, Skinner DC. Somatostatin-14 neurons in the ovine hypothalamus: colocalization with estrogen receptor alpha and somatostatin-28(1-12) immunoreactivity, and activation in response to estradiol. Biol Reprod 2003; 4: 1318-1324. 
35. Tillet Y, Tourlet S, Picard S, Sizaret PY, Caraty A. Morphofunctional interactions between galanin and GnRH-containing neurones in the diencephalon of the ewe. The effect of oestradiol. J Chem Neuroanat 2012; 1: 14-19.

36. Foradori CD, Amstalden M, Coolen LM, Singh SR, McManus CJ, Handa RJ, Goodman RL, Lehman MN. Orphanin FQ: evidence for a role in the control of the reproductive neuroendocrine system. Endocrinology 2007; 10: 4993-5001.

37. Smith JT, Clarke IJ. Gonadotropin inhibitory hormone function in mammals. Trends Endocrinol Metab 2010; 4: 255-260.

38. Goodman RL, Lehman MN. Kisspeptin neurons from mice to men: similarities and differences. Endocrinology 2012; 11: 5105-5118.

39. Franceschini I, Lomet D, Cateau M, Delsol G, Tillet Y, Caraty A. Kisspeptin immunoreactive cells of the ovine preoptic area and arcuate nucleus co-express estrogen receptor alpha. Neurosci Lett 2006; 3: 225-230.

40. Goodman RL, Lehman MN, Smith JT, Coolen LM, de Oliveira CV, Jafarzadehshirazi MR, Pereira A, Iqbal J, Caraty A, Ciofi P, Clarke IJ. Kisspeptin neurons in the arcuate nucleus of the ewe express both dynorphin A and neurokinin B. Endocrinology 2007; 12: 5752-5760.

41. Smith JT, Li Q, Yap KS, Shahab M, Roseweir AK, Millar RP, Clarke IJ. Kisspeptin is essential for the full preovulatory LH surge and stimulates GnRH release from the isolated ovine median eminence. Endocrinology 2011; 3: 1001-1012. 
42. Merkley CM, Coolen LM, Goodman RL, Lehman MN. Evidence for changes in numbers of synaptic inputs onto KNDy and GnRH neurones during the preovulatory LH surge in the ewe. J Neuroendocrinol 2015.

43. Smith JT, Clay CM, Caraty A, Clarke IJ. KiSS-1 messenger ribonucleic acid expression in the hypothalamus of the ewe is regulated by sex steroids and season. Endocrinology 2007; 3: 1150-1157.

44. Bedenbaugh MN, D'Oliveira M, Cardoso RC, Hileman SM, Williams GL, Amstalden M. Pubertal escape from estradiol negative feedback in ewe lambs is not accounted for by decreased ESR1 mRNA or protein in kisspeptin neurons. Endocrinology 2017.

45. Moenter SM, Brand RM, Midgley AR, Karsch FJ. Dynamics of gonadotropin-releasing hormone release during a pulse. Endocrinology 1992; 1: 503-510.

46. Goodman RL, Maltby MJ, Millar RP, Hileman SM, Nestor CC, Whited B, Tseng AS, Coolen LM, Lehman MN. Evidence That Dopamine Acts via Kisspeptin to Hold GnRH Pulse Frequency in Check in Anestrous Ewes. Endocrinology 2012; 12: 5918-5927.

47. Roseweir AK, Kauffman AS, Smith JT, Guerriero KA, Morgan K, Pielecka-Fortuna J, Pineda R, Gottsch ML, Tena-Sempere M, Moenter SM, Terasawa E, Clarke IJ, Steiner RA, Millar RP. Discovery of potent kisspeptin antagonists delineate physiological mechanisms of gonadotropin regulation. J Neurosci 2009; 12: 3920-3929. 
48. Foradori CD, Amstalden M, Goodman RL, Lehman MN. Colocalisation of dynorphin a and neurokinin B immunoreactivity in the arcuate nucleus and median eminence of the sheep. J Neuroendocrinol 2006; 7: 534-541.

49. Wakabayashi Y, Yamamura T, Sakamoto K, Mori Y, Okamura H. Electrophysiological and morphological evidence for synchronized GnRH pulse generator activity among Kisspeptin/neurokinin B/dynorphin A (KNDy) neurons in goats. J Reprod Dev 2013; 1: 40-48.

50. Ohkura S, Takase K, Matsuyama S, Mogi K, Ichimaru T, Wakabayashi Y, Uenoyama Y, Mori Y, Steiner RA, Tsukamura H, Maeda KI, Okamura H. Gonadotrophin-releasing hormone pulse generator activity in the hypothalamus of the goat. J Neuroendocrinol 2009; 10: 813-821.

51. Smith JT, Li Q, Pereira A, Clarke IJ. Kisspeptin neurons in the ovine arcuate nucleus and preoptic area are involved in the preovulatory luteinizing hormone surge. Endocrinology 2009; 12: $5530-5538$.

52. Amstalden M, Coolen LM, Hemmerle AM, Billings HJ, Connors JM, Goodman RL, Lehman MN. Neurokinin 3 receptor immunoreactivity in the septal region, preoptic area and hypothalamus of the female sheep: colocalisation in neurokinin B cells of the arcuate nucleus but not in gonadotrophin-releasing hormone neurones. J Neuroendocrinol 2010; 1: 1-12.

53. Wakabayashi Y, Nakada T, Murata K, Ohkura S, Mogi K, Navarro VM, Clifton DK, Mori Y, Tsukamura H, Maeda K, Steiner RA, Okamura H. Neurokinin B and dynorphin A in kisspeptin neurons of the arcuate nucleus participate in generation of periodic oscillation of neural activity driving pulsatile gonadotropin-releasing hormone secretion in the goat. J Neurosci 2010; 8: 3124-3132. 
54. Sakamoto K, Murata K, Wakabayashi Y, Yayou K, Ohkura S, Takeuchi Y, Mori Y, Okamura H. Central administration of neurokinin B activates kisspeptin/NKB neurons in the arcuate nucleus and stimulates luteinizing hormone secretion in ewes during the non-breeding season. J Reprod Dev 2012; 6: 700-706.

55. Goodman RL, Hileman SM, Nestor CC, Porter KL, Connors JM, Hardy SL, Millar RP, Cernea M, Coolen LM, Lehman MN. Kisspeptin, neurokinin B, and dynorphin act in the arcuate nucleus to control activity of the GnRH pulse generator in ewes. Endocrinology 2013; 11: 42594269.

56. Goodman RL, Parfitt DB, Evans NP, Dahl GE, Karsch FJ. Endogenous opioid peptides control the amplitude and shape of gonadotropin-releasing hormone pulses in the ewe. Endocrinology 1995; 6: 2412-2420.

57. Goldman BD. Mammalian photoperiodic system: formal properties and neuroendocrine mechanisms of photoperiodic time measurement. J Biol Rhythms 2001; 4: 283-301.

58. Legan SJ, Karsch FJ, Foster DL. The endocrin control of seasonal reproductive function in the ewe: a marked change in response to the negative feedback action of estradiol on luteinizing hormone secretion. Endocrinology 1977; 3: 818-824.

59. Knobil E. On the control of gonadotropin secretion in the rhesus monkey. Recent Prog Horm Res 1974; 0: 1-46.

60. Ramaswamy S, Guerriero KA, Gibbs RB, Plant TM. Structural interactions between kisspeptin and GnRH neurons in the mediobasal hypothalamus of the male rhesus monkey 
(Macaca mulatta) as revealed by double immunofluorescence and confocal microscopy. Endocrinology 2008; 9: 4387-4395.

61. Krey LC, Lu KH, Bulter WR, Hotchkiss J, Piva F, Knobil E. Surgical disconnection of the medial basal hypothalamus and pituitary function in the rhesus monkey. II. GH and cortisol secretion. Endocrinology 1975; 5: 1088-1093.

62. Plant TM, Krey LC, Moossy J, McCormack JT, Hess DL, Knobil E. The arcuate nucleus and the control of gonadotropin and prolactin secretion in the female rhesus monkey (Macaca mulatta). Endocrinology 1978; 1: 52-62.

63. Chan YM, Butler JP, Sidhoum VF, Pinnell NE, Seminara SB. Kisspeptin administration to women: a window into endogenous kisspeptin secretion and GnRH responsiveness across the menstrual cycle. J Clin Endocrinol Metab 2012; 8: E1458-67.

64. Foster D, Hileman S. Puberty in the Sheep. In: Zeleznik A and Plant T, eds. Knobil and Neill's Physiology of Reproduction. New York/Oxford, UK: Elsevier/Academic, 2015: 14411485.

65. Land RB, Thimonier J, Pelletier J. Possibility of the induction of LH secretion by injection of estrogen in the female lamb as a function of age. C R Acad Sci Hebd Seances Acad Sci D 1970; 17: 1549-1551.

66. Foster DL. Preovulatory gonadotropin surge system of prepubertal female sheep is exquisitely sensitive to the stimulatory feedback action of estradiol. Endocrinology 1984; 3: 1186-1189. 
67. Squires EL, Scaramuzzi RJ, Caldwell BV, Inskeep EK. LH release and ovulation in the prepuberal lamb. J Anim Sci 1972; 4: 614-619.

68. Foster DL, Ryan KD, Papkoff H. Hourly administration of luteinizing hormone induces ovulation in prepubertal female sheep. Endocrinology 1984; 3: 1179-1185.

69. Foster DL, Ryan KD. Endocrine mechanisms governing transition into adulthood: a marked decrease in inhibitory feedback action of estradiol on tonic secretion of luteinizing hormone in the lamb during puberty. Endocrinology 1979; 4: 896-904.

70. Ebling FJ, Kushler RH, Foster DL. Pulsatile LH secretion during sexual maturation in the female sheep: photoperiodic regulation in the presence and absence of ovarian steroid feedback as determined in the same individual. Neuroendocrinology 1990; 3: 229-237.

71. Olster DH, Foster DL. Control of gonadotropin secretion in the male during puberty: a decrease in response to steroid inhibitory feedback in the absence of an increase in steroidindependent drive in the sheep. Endocrinology 1986; 6: 2225-2234.

72. Foster DL, Ryan KD, Goodman RL, Legan SJ, Karsch FJ, Yellon SM. Delayed puberty in lambs chronically treated with oestradiol. J Reprod Fertil 1986; 1: 111-117.

73. Foster D, Ebling F, Vannerson L, Wood R, Fenner D. Regulation of puberty in the lamb: internal and external cues. In: Imura H, Shizume K and Yoshida S, eds. Progress in endocrinology, 1988: 861-866. 
74. Lee JH, Miele ME, Hicks DJ, Phillips KK, Trent JM, Weissman BE, Welch DR. KiSS-1, a novel human malignant melanoma metastasis-suppressor gene. J Natl Cancer Inst 1996; 23: 1731-1737.

75. Kotani M, Detheux M, Vandenbogaerde A, Communi D, Vanderwinden JM, Le Poul E, Brezillon S, Tyldesley R, Suarez-Huerta N, Vandeput F, Blanpain C, Schiffmann SN, Vassart G, Parmentier M. The metastasis suppressor gene KiSS-1 encodes kisspeptins, the natural ligands of the orphan G protein-coupled receptor GPR54. J Biol Chem 2001; 37: 34631-34636.

76. Ohtaki T, Shintani Y, Honda S, Matsumoto H, Hori A, Kanehashi K, Terao Y, Kumano S, Takatsu Y, Masuda Y, Ishibashi Y, Watanabe T, Asada M, Yamada T, Suenaga M, Kitada C, Usuki S, Kurokawa T, Onda H, Nishimura O, Fujino M. Metastasis suppressor gene KiSS-1 encodes peptide ligand of a G-protein-coupled receptor. Nature 2001; 6837: 613-617.

77. Clarkson J, d'Anglemont de Tassigny X, Colledge WH, Caraty A, Herbison AE. Distribution of kisspeptin neurones in the adult female mouse brain. J Neuroendocrinol 2009; 8: 673-682.

78. Merkley CM, Porter KL, Coolen LM, Hileman SM, Billings HJ, Drews S, Goodman RL, Lehman MN. KNDy (Kisspeptin/Neurokinin B/Dynorphin) Neurons Are Activated during Both Pulsatile and Surge Secretion of LH in the Ewe. Endocrinology 2012; 11: 5406-5414.

79. Smith JT, Shahab M, Pereira A, Pau KY, Clarke IJ. Hypothalamic expression of KISS1 and gonadotropin inhibitory hormone genes during the menstrual cycle of a non-human primate. Biol Reprod 2010; 4: 568-577. 
80. Gottsch ML, Cunningham MJ, Smith JT, Popa SM, Acohido BV, Crowley WF, Seminara S, Clifton DK, Steiner RA. A role for kisspeptins in the regulation of gonadotropin secretion in the mouse. Endocrinology 2004; 9: 4073-4077.

81. Kauffman AS, Gottsch ML, Roa J, Byquist AC, Crown A, Clifton DK, Hoffman GE, Steiner RA, Tena-Sempere M. Sexual differentiation of Kiss1 gene expression in the brain of the rat. Endocrinology 2007; 4: 1774-1783.

82. Adachi S, Yamada S, Takatsu Y, Matsui H, Kinoshita M, Takase K, Sugiura H, Ohtaki T, Matsumoto H, Uenoyama Y, Tsukamura H, Inoue K, Maeda K. Involvement of anteroventral periventricular metastin/kisspeptin neurons in estrogen positive feedback action on luteinizing hormone release in female rats. J Reprod Dev 2007; 2: 367-378.

83. Vargas Trujillo M, Kalil B, Ramaswamy S, Plant TM. Estradiol Upregulates Kisspeptin Expression in the Preoptic Area of both the Male and Female Rhesus Monkey (Macaca mulatta): Implications for the Hypothalamic Control of Ovulation in Highly Evolved Primates. Neuroendocrinology 2017; 1: 77-89.

84. Hrabovszky E, Ciofi P, Vida B, Horvath MC, Keller E, Caraty A, Bloom SR, Ghatei MA, Dhillo WS, Liposits Z, Kallo I. The kisspeptin system of the human hypothalamus: sexual dimorphism and relationship with gonadotropin-releasing hormone and neurokinin B neurons. Eur J Neurosci 2010; 11: 1984-1998.

85. Kallo I, Vida B, Deli L, Molnar CS, Hrabovszky E, Caraty A, Ciofi P, Coen CW, Liposits Z. Co-localisation of kisspeptin with galanin or neurokinin B in afferents to mouse GnRH neurones. J Neuroendocrinol 2012; 3: 464-476. 
86. Porteous R, Petersen SL, Yeo SH, Bhattarai JP, Ciofi P, de Tassigny XD, Colledge WH, Caraty A, Herbison AE. Kisspeptin neurons co-express met-enkephalin and galanin in the rostral periventricular region of the female mouse hypothalamus. J Comp Neurol 2011; 17: 3456-3469.

87. Cravo RM, Margatho LO, Osborne-Lawrence S, Donato J,Jr, Atkin S, Bookout AL, Rovinsky S, Frazao R, Lee CE, Gautron L, Zigman JM, Elias CF. Characterization of Kiss1 neurons using transgenic mouse models. Neuroscience 2011; : 37-56.

88. Clarkson J, Herbison AE. Dual phenotype kisspeptin-dopamine neurones of the rostral periventricular area of the third ventricle project to gonadotrophin-releasing hormone neurones. J Neuroendocrinol 2011; 4: 293-301.

89. Lehman MN, Coolen LM, Goodman RL. Minireview: kisspeptin/neurokinin B/dynorphin (KNDy) cells of the arcuate nucleus: a central node in the control of gonadotropin-releasing hormone secretion. Endocrinology 2010; 8: 3479-3489.

90. Ciofi P, Leroy D, Tramu G. Sexual dimorphism in the organization of the rat hypothalamic infundibular area. Neuroscience 2006; 4: 1731-1745.

91. Kim J, Semaan SJ, Clifton DK, Steiner RA, Dhamija S, Kauffman AS. Regulation of Kiss1 expression by sex steroids in the amygdala of the rat and mouse. Endocrinology 2011; 5: 20202030.

92. Castellano JM, Gaytan M, Roa J, Vigo E, Navarro VM, Bellido C, Dieguez C, Aguilar E, Sanchez-Criado JE, Pellicer A, Pinilla L, Gaytan F, Tena-Sempere M. Expression of KiSS-1 in rat ovary: putative local regulator of ovulation?. Endocrinology 2006; 10: 4852-4862. 
93. Castellano JM, Navarro VM, Fernandez-Fernandez R, Castano JP, Malagon MM, Aguilar E, Dieguez C, Magni P, Pinilla L, Tena-Sempere M. Ontogeny and mechanisms of action for the stimulatory effect of kisspeptin on gonadotropin-releasing hormone system of the rat. Mol Cell Endocrinol 2006; : 75-83.

94. Torricelli M, Galleri L, Voltolini C, Biliotti G, Florio P, De Bonis M, Petraglia F. Changes of placental Kiss-1 mRNA expression and maternal/cord kisspeptin levels at preterm delivery. Reprod Sci 2008; 8: 779-784.

95. Terao Y, Kumano S, Takatsu Y, Hattori M, Nishimura A, Ohtaki T, Shintani Y. Expression of KiSS-1, a metastasis suppressor gene, in trophoblast giant cells of the rat placenta. Biochim Biophys Acta 2004; 2-3: 102-110.

96. Seminara SB, Messager S, Chatzidaki EE, Thresher RR, Acierno JS,Jr, Shagoury JK, BoAbbas Y, Kuohung W, Schwinof KM, Hendrick AG, Zahn D, Dixon J, Kaiser UB, Slaugenhaupt SA, Gusella JF, O'Rahilly S, Carlton MB, Crowley WF,Jr, Aparicio SA, Colledge WH. The GPR54 gene as a regulator of puberty. N Engl J Med 2003; 17: 1614-1627.

97. de Roux N, Genin E, Carel JC, Matsuda F, Chaussain JL, Milgrom E. Hypogonadotropic hypogonadism due to loss of function of the KiSS1-derived peptide receptor GPR54. Proc Natl Acad Sci U S A 2003; 19: 10972-10976.

98. Oakley AE, Clifton DK, Steiner RA. Kisspeptin signaling in the brain. Endocr Rev 2009; 6: 713-743. 
99. Navarro VM, Castellano JM, Fernandez-Fernandez R, Barreiro ML, Roa J, Sanchez-Criado JE, Aguilar E, Dieguez C, Pinilla L, Tena-Sempere M. Developmental and hormonally regulated messenger ribonucleic acid expression of KiSS-1 and its putative receptor, GPR54, in rat hypothalamus and potent luteinizing hormone-releasing activity of KiSS-1 peptide. Endocrinology 2004; 10: 4565-4574.

100. Keen KL, Wegner FH, Bloom SR, Ghatei MA, Terasawa E. An increase in kisspeptin-54 release occurs with the pubertal increase in luteinizing hormone-releasing hormone-1 release in the stalk-median eminence of female rhesus monkeys in vivo. Endocrinology 2008; 8: 41514157.

101. Redmond JS, Macedo GG, Velez IC, Caraty A, Williams GL, Amstalden M. Kisspeptin activates the hypothalamic-adenohypophyseal-gonadal axis in prepubertal ewe lambs. Reproduction 2011; 4: 541-548.

102. Messager S, Chatzidaki EE, Ma D, Hendrick AG, Zahn D, Dixon J, Thresher RR, Malinge I, Lomet D, Carlton MB, Colledge WH, Caraty A, Aparicio SA. Kisspeptin directly stimulates gonadotropin-releasing hormone release via G protein-coupled receptor 54. Proc Natl Acad Sci U S A 2005; 5: 1761-1766.

103. Shahab M, Mastronardi C, Seminara SB, Crowley WF, Ojeda SR, Plant TM. Increased hypothalamic GPR54 signaling: a potential mechanism for initiation of puberty in primates. Proc Natl Acad Sci U S A 2005; 6: 2129-2134. 
104. Dungan HM, Gottsch ML, Zeng H, Gragerov A, Bergmann JE, Vassilatis DK, Clifton DK, Steiner RA. The role of kisspeptin-GPR54 signaling in the tonic regulation and surge release of gonadotropin-releasing hormone/luteinizing hormone. J Neurosci 2007; 44: 12088-12095.

105. Han SK, Gottsch ML, Lee KJ, Popa SM, Smith JT, Jakawich SK, Clifton DK, Steiner RA, Herbison AE. Activation of gonadotropin-releasing hormone neurons by kisspeptin as a neuroendocrine switch for the onset of puberty. J Neurosci 2005; 49: 11349-11356.

106. Herbison AE, de Tassigny X, Doran J, Colledge WH. Distribution and postnatal development of Gpr54 gene expression in mouse brain and gonadotropin-releasing hormone neurons. Endocrinology 2010; 1: 312-321.

107. Clarkson J, Herbison AE. Postnatal development of kisspeptin neurons in mouse hypothalamus; sexual dimorphism and projections to gonadotropin-releasing hormone neurons. Endocrinology 2006; 12: 5817-5825.

108. Nestor CC, Briscoe AM, Davis SM, Valent M, Goodman RL, Hileman SM. Evidence of a role for kisspeptin and neurokinin B in puberty of female sheep. Endocrinology 2012; 6: 27562765.

109. Matsui H, Takatsu Y, Kumano S, Matsumoto H, Ohtaki T. Peripheral administration of metastin induces marked gonadotropin release and ovulation in the rat. Biochem Biophys Res Commun 2004; 2: 383-388.

110. Smith JT, Rao A, Pereira A, Caraty A, Millar RP, Clarke IJ. Kisspeptin is present in ovine hypophysial portal blood but does not increase during the preovulatory luteinizing hormone 
surge: evidence that gonadotropes are not direct targets of kisspeptin in vivo. Endocrinology 2008; 4: 1951-1959.

111. Arreguin-Arevalo JA, Lents CA, Farmerie TA, Nett TM, Clay CM. KiSS-1 peptide induces release of LH by a direct effect on the hypothalamus of ovariectomized ewes. Anim Reprod Sci 2007; 3-4: 265-275.

112. Hanchate NK, Parkash J, Bellefontaine N, Mazur D, Colledge WH, d'Anglemont de Tassigny X, Prevot V. Kisspeptin-GPR54 signaling in mouse NO-synthesizing neurons participates in the hypothalamic control of ovulation. J Neurosci 2012; 3: 932-945.

113. Parkash J, d'Anglemont de Tassigny X, Bellefontaine N, Campagne C, Mazure D, BueeScherrer V, Prevot V. Phosphorylation of N-methyl-D-aspartic acid receptor-associated neuronal nitric oxide synthase depends on estrogens and modulates hypothalamic nitric oxide production during the ovarian cycle. Endocrinology 2010; 6: 2723-2735.

114. Clasadonte J, Poulain P, Beauvillain JC, Prevot V. Activation of neuronal nitric oxide release inhibits spontaneous firing in adult gonadotropin-releasing hormone neurons: a possible local synchronizing signal. Endocrinology 2008; 2: 587-596.

115. d'Anglemont de Tassigny X, Campagne C, Dehouck B, Leroy D, Holstein GR, Beauvillain JC, Buee-Scherrer V, Prevot V. Coupling of neuronal nitric oxide synthase to NMDA receptors via postsynaptic density-95 depends on estrogen and contributes to the central control of adult female reproduction. J Neurosci 2007; 23: 6103-6114. 
116. Pielecka-Fortuna J, Chu Z, Moenter SM. Kisspeptin acts directly and indirectly to increase gonadotropin-releasing hormone neuron activity and its effects are modulated by estradiol. Endocrinology 2008; 4: 1979-1986.

117. Pielecka-Fortuna J, Moenter SM. Kisspeptin increases gamma-aminobutyric acidergic and glutamatergic transmission directly to gonadotropin-releasing hormone neurons in an estradioldependent manner. Endocrinology 2010; 1: 291-300.

118. Lapatto R, Pallais JC, Zhang D, Chan YM, Mahan A, Cerrato F, Le WW, Hoffman GE, Seminara SB. Kiss1-/- mice exhibit more variable hypogonadism than Gpr54-/- mice. Endocrinology 2007; 10: 4927-4936.

119. Mayer C, Boehm U. Female reproductive maturation in the absence of kisspeptin/GPR54 signaling. Nat Neurosci 2011; 6: 704-710.

120. Decourt C, Robert V, Anger K, Galibert M, Madinier JB, Liu X, Dardente H, Lomet D, Delmas AF, Caraty A, Herbison AE, Anderson GM, Aucagne V, Beltramo M. A synthetic kisspeptin analog that triggers ovulation and advances puberty. Sci Rep 2016; : 26908.

121. Redmond JS, Baez-Sandoval GM, Spell KM, Spencer TE, Lents CA, Williams GL, Amstalden M. Developmental changes in hypothalamic Kiss1 expression during activation of the pulsatile release of luteinising hormone in maturing ewe lambs. J Neuroendocrinol 2011; 9: 815822.

122. Takase K, Uenoyama Y, Inoue N, Matsui H, Yamada S, Shimizu M, Homma T, Tomikawa J, Kanda S, Matsumoto H, Oka Y, Tsukamura H, Maeda KI. Possible role of oestrogen in 
pubertal increase of Kiss1/kisspeptin expression in discrete hypothalamic areas of female rats. J Neuroendocrinol 2009; 6: 527-537.

123. Takumi K, Iijima N, Ozawa H. Developmental changes in the expression of kisspeptin mRNA in rat hypothalamus. J Mol Neurosci 2011; 2: 138-145.

124. Smith JT, Cunningham MJ, Rissman EF, Clifton DK, Steiner RA. Regulation of Kiss1 gene expression in the brain of the female mouse. Endocrinology 2005; 9: 3686-3692.

125. Smith JT, Dungan HM, Stoll EA, Gottsch ML, Braun RE, Eacker SM, Clifton DK, Steiner RA. Differential regulation of KiSS-1 mRNA expression by sex steroids in the brain of the male mouse. Endocrinology 2005; 7: 2976-2984.

126. Rometo AM, Krajewski SJ, Voytko ML, Rance NE. Hypertrophy and increased kisspeptin gene expression in the hypothalamic infundibular nucleus of postmenopausal women and ovariectomized monkeys. J Clin Endocrinol Metab 2007; 7: 2744-2750.

127. Guerriero KA, Keen KL, Terasawa E. Developmental increase in kisspeptin-54 release in vivo is independent of the pubertal increase in estradiol in female rhesus monkeys (Macaca mulatta). Endocrinology 2012; 4: 1887-1897.

128. Smith JT. Kisspeptin signalling in the brain: steroid regulation in the rodent and ewe. Brain Res Rev 2008; 2: 288-298.

129. Clarkson J, Boon WC, Simpson ER, Herbison AE. Postnatal development of an estradiolkisspeptin positive feedback mechanism implicated in puberty onset. Endocrinology 2009; 7: 3214-3220. 
130. Castellano JM, Bentsen AH, Mikkelsen JD, Tena-Sempere M. Kisspeptins: bridging energy homeostasis and reproduction. Brain Res 2010; : 129-138.

131. Herbison AE. Estrogen positive feedback to gonadotropin-releasing hormone (GnRH) neurons in the rodent: the case for the rostral periventricular area of the third ventricle (RP3V). Brain Res Rev 2008; 2: 277-287.

132. Smith JT, Popa SM, Clifton DK, Hoffman GE, Steiner RA. Kiss1 neurons in the forebrain as central processors for generating the preovulatory luteinizing hormone surge. $\mathrm{J}$ Neurosci 2006; 25: 6687-6694.

133. Kinoshita M, Tsukamura H, Adachi S, Matsui H, Uenoyama Y, Iwata K, Yamada S, Inoue K, Ohtaki T, Matsumoto H, Maeda K. Involvement of central metastin in the regulation of preovulatory luteinizing hormone surge and estrous cyclicity in female rats. Endocrinology 2005; 10: 4431-4436.

134. Caraty A, Fabre-Nys C, Delaleu B, Locatelli A, Bruneau G, Karsch FJ, Herbison A. Evidence that the mediobasal hypothalamus is the primary site of action of estradiol in inducing the preovulatory gonadotropin releasing hormone surge in the ewe. Endocrinology 1998; 4: 1752-1760.

135. Weick RF. Induction of the luteinizing hormone surge by intrahypothalamic application of estrogen in the rhesus monkey. Biol Reprod 1981; 2: 415-422. 
136. Hoffman GE, Le WW, Franceschini I, Caraty A, Advis JP. Expression of fos and in vivo median eminence release of LHRH identifies an active role for preoptic area kisspeptin neurons in synchroniz. Endocrinology 2011; 1: 214-222.

137. Mayer C, Acosta-Martinez M, Dubois SL, Wolfe A, Radovick S, Boehm U, Levine JE. Timing and completion of puberty in female mice depend on estrogen receptor alpha-signaling in kisspeptin neurons. Proc Natl Acad Sci U S A 2010; 52: 22693-22698.

138. Gottsch ML, Navarro VM, Zhao Z, Glidewell-Kenney C, Weiss J, Jameson JL, Clifton DK, Levine JE, Steiner RA. Regulation of Kiss1 and dynorphin gene expression in the murine brain by classical and nonclassical estrogen receptor pathways. J Neurosci 2009; 29: 9390-9395.

139. Roa J, Vigo E, Castellano JM, Gaytan F, Navarro VM, Aguilar E, Dijcks FA, Ederveen AG, Pinilla L, van Noort PI, Tena-Sempere M. Opposite roles of estrogen receptor (ER)-alpha and ERbeta in the modulation of luteinizing hormone responses to kisspeptin in the female rat: implications for the generation of the preovulatory surge. Endocrinology 2008; 4: 1627-1637.

140. Alcin E, Sahu A, Ramaswamy S, Hutz ED, Keen KL, Terasawa E, Bethea CL, Plant TM. Ovarian Regulation of Kisspeptin Neurones in the Arcuate Nucleus of the Rhesus Monkey (Macaca mulatta). J Neuroendocrinol 2013; 5: 488-496.

141. Mittelman-Smith MA, Williams H, Krajewski-Hall SJ, Lai J, Ciofi P, McMullen NT, Rance NE. Arcuate kisspeptin/neurokinin B/dynorphin (KNDy) neurons mediate the estrogen suppression of gonadotropin secretion and body weight. Endocrinology 2012; 6: 2800-2812. 
142. Almeida TA, Rojo J, Nieto PM, Pinto FM, Hernandez M, Martin JD, Candenas ML. Tachykinins and tachykinin receptors: structure and activity relationships. Curr Med Chem 2004; 15: 2045-2081.

143. Helke CJ, Krause JE, Mantyh PW, Couture R, Bannon MJ. Diversity in mammalian tachykinin peptidergic neurons: multiple peptides, receptors, and regulatory mechanisms. FASEB J 1990; 6: 1606-1615.

144. Rance NE, Krajewski SJ, Smith MA, Cholanian M, Dacks PA. Neurokinin B and the hypothalamic regulation of reproduction. Brain Res 2010; : 116-128.

145. Satake H, Kawada T. Overview of the primary structure, tissue-distribution, and functions of tachykinins and their receptors. Curr Drug Targets 2006; 8: 963-974.

146. Haley GE, Flynn FW. Agonist and hypertonic saline-induced trafficking of the NK3receptors on vasopressin neurons within the paraventricular nucleus of the hypothalamus. Am J Physiol Regul Integr Comp Physiol 2006; 5: R1242-50.

147. Pennefather JN, Lecci A, Candenas ML, Patak E, Pinto FM, Maggi CA. Tachykinins and tachykinin receptors: a growing family. Life Sci 2004; 12: 1445-1463.

148. Ramaswamy S, Seminara SB, Ali B, Ciofi P, Amin NA, Plant TM. Neurokinin B stimulates GnRH release in the male monkey (Macaca mulatta) and is colocalized with kisspeptin in the arcuate nucleus. Endocrinology 2010; 9: 4494-4503. 
149. Sandoval-Guzman T, Stalcup ST, Krajewski SJ, Voytko ML, Rance NE. Effects of ovariectomy on the neuroendocrine axes regulating reproduction and energy balance in young cynomolgus macaques. J Neuroendocrinol 2004; 2: 146-153.

150. Duarte CR, Schutz B, Zimmer A. Incongruent pattern of neurokinin B expression in rat and mouse brains. Cell Tissue Res 2006; 1: 43-51.

151. Navarro VM, Gottsch ML, Chavkin C, Okamura H, Clifton DK, Steiner RA. Regulation of gonadotropin-releasing hormone secretion by kisspeptin/dynorphin/neurokinin B neurons in the arcuate nucleus of the mouse. J Neurosci 2009; 38: 11859-11866.

152. Krajewski SJ, Burke MC, Anderson MJ, McMullen NT, Rance NE. Forebrain projections of arcuate neurokinin B neurons demonstrated by anterograde tract-tracing and monosodium glutamate lesions in the rat. Neuroscience 2010; 2: 680-697.

153. Lucas LR, Hurley DL, Krause JE, Harlan RE. Localization of the tachykinin neurokinin B precursor peptide in rat brain by immunocytochemistry and in situ hybridization. Neuroscience 1992; 2: 317-345.

154. Marksteiner J, Sperk G, Krause JE. Distribution of neurons expressing neurokinin B in the rat brain: immunohistochemistry and in situ hybridization. J Comp Neurol 1992; 4: 341-356.

155. Merchenthaler I, Maderdrut JL, O'Harte F, Conlon JM. Localization of neurokinin B in the central nervous system of the rat. Peptides 1992; 4: 815-829. 
156. Chawla MK, Gutierrez GM, Young WS,3rd, McMullen NT, Rance NE. Localization of neurons expressing substance $\mathrm{P}$ and neurokinin $\mathrm{B}$ gene transcripts in the human hypothalamus and basal forebrain. J Comp Neurol 1997; 3: 429-442.

157. Krajewski SJ, Anderson MJ, Iles-Shih L, Chen KJ, Urbanski HF, Rance NE. Morphologic evidence that neurokinin B modulates gonadotropin-releasing hormone secretion via neurokinin 3 receptors in the rat median eminence. J Comp Neurol 2005; 3: 372-386.

158. Ding YQ, Shigemoto R, Takada M, Ohishi H, Nakanishi S, Mizuno N. Localization of the neuromedin K receptor (NK3) in the central nervous system of the rat. J Comp Neurol 1996; 2: 290-310.

159. Rance NE, Young WS,3rd. Hypertrophy and increased gene expression of neurons containing neurokinin-B and substance-P messenger ribonucleic acids in the hypothalami of postmenopausal women. Endocrinology 1991; 5: 2239-2247.

160. Rance NE. Menopause and the human hypothalamus: evidence for the role of kisspeptin/neurokinin B neurons in the regulation of estrogen negative feedback. Peptides 2009; 1: $111-122$.

161. Abel TW, Voytko ML, Rance NE. The effects of hormone replacement therapy on hypothalamic neuropeptide gene expression in a primate model of menopause. J Clin Endocrinol Metab 1999; 6: 2111-2118.

162. Rance NE, Bruce TR. Neurokinin B gene expression is increased in the arcuate nucleus of ovariectomized rats. Neuroendocrinology 1994; 4: 337-345. 
163. Topaloglu AK, Reimann F, Guclu M, Yalin AS, Kotan LD, Porter KM, Serin A, Mungan NO, Cook JR, Ozbek MN, Imamoglu S, Akalin NS, Yuksel B, O'Rahilly S, Semple RK. TAC3 and TACR3 mutations in familial hypogonadotropic hypogonadism reveal a key role for Neurokinin B in the central control of reproduction. Nat Genet 2009; 3: 354-358.

164. Young J, Bouligand J, Francou B, Raffin-Sanson ML, Gaillez S, Jeanpierre M, Grynberg M, Kamenicky P, Chanson P, Brailly-Tabard S, Guiochon-Mantel A. TAC3 and TACR3 defects cause hypothalamic congenital hypogonadotropic hypogonadism in humans. J Clin Endocrinol Metab 2010; 5: 2287-2295.

165. Burke MC, Letts PA, Krajewski SJ, Rance NE. Coexpression of dynorphin and neurokinin B immunoreactivity in the rat hypothalamus: Morphologic evidence of interrelated function within the arcuate nucleus. J Comp Neurol 2006; 5: 712-726.

166. Navarro VM, Gottsch ML, Wu M, Garcia-Galiano D, Hobbs SJ, Bosch MA, Pinilla L, Clifton DK, Dearth A, Ronnekleiv OK, Braun RE, Palmiter RD, Tena-Sempere M, Alreja M, Steiner RA. Regulation of NKB pathways and their roles in the control of Kiss1 neurons in the arcuate nucleus of the male mouse. Endocrinology 2011; 11: 4265-4275.

167. Billings HJ, Connors JM, Altman SN, Hileman SM, Holaskova I, Lehman MN, McManus CJ, Nestor CC, Jacobs BH, Goodman RL. Neurokinin B acts via the neurokinin-3 receptor in the retrochiasmatic area to stimulate luteinizing hormone secretion in sheep. Endocrinology 2010; 8: 3836-3846. 
168. Garcia JP, Guerriero KA, Keen KL, Kenealy BP, Seminara SB, Terasawa E. Kisspeptin and Neurokinin B Signaling Network Underlies the Pubertal Increase in GnRH Release in Female Rhesus Monkeys. Endocrinology 2017; 10: 3269-3280.

169. Navarro VM, Castellano JM, McConkey SM, Pineda R, Ruiz-Pino F, Pinilla L, Clifton DK, Tena-Sempere M, Steiner RA. Interactions between kisspeptin and neurokinin B in the control of GnRH secretion in the female rat. Am J Physiol Endocrinol Metab 2011; 1: E202-10.

170. Kinsey-Jones JS, Grachev P, Li XF, Lin YS, Milligan SR, Lightman SL, O'Byrne KT. The inhibitory effects of neurokinin B on GnRH pulse generator frequency in the female rat. Endocrinology 2012; 1: 307-315.

171. Porter KL, Hileman SM, Hardy SL, Nestor CC, Lehman MN, Goodman RL. Neurokinin-3 receptor activation in the retrochiasmatic area is essential for the full pre-ovulatory luteinising hormone surge in ewes. J Neuroendocrinol 2014; 11: 776-784.

172. Gianetti E, Tusset C, Noel SD, Au MG, Dwyer AA, Hughes VA, Abreu AP, Carroll J, Trarbach E, Silveira LF, Costa EM, de Mendonca BB, de Castro M, Lofrano A, Hall JE, Bolu E, Ozata M, Quinton R, Amory JK, Stewart SE, Arlt W, Cole TR, Crowley WF, Kaiser UB, Latronico AC, Seminara SB. TAC3/TACR3 mutations reveal preferential activation of gonadotropin-releasing hormone release by neurokinin B in neonatal life followed by reversal in adulthood. J Clin Endocrinol Metab 2010; 6: 2857-2867.

173. True C, Nasrin Alam S, Cox K, Chan YM, Seminara SB. Neurokinin B is critical for normal timing of sexual maturation but dispensable for adult reproductive function in female mice. Endocrinology 2015; 4: 1386-1397. 
174. Li SY, Li XF, Hu MH, Shao B, Poston L, Lightman SL, O'Byrne KT. Neurokinin B receptor antagonism decreases luteinising hormone pulse frequency and amplitude and delays puberty onset in the female rat. J Neuroendocrinol 2014; 8: 521-527.

175. Kauffman AS, Navarro VM, Kim J, Clifton DK, Steiner RA. Sex differences in the regulation of Kiss1/NKB neurons in juvenile mice: implications for the timing of puberty. Am J Physiol Endocrinol Metab 2009; 5: E1212-21.

176. Goubillon ML, Caraty A, Herbison AE. Evidence in favour of a direct input from the ventromedial nucleus to gonadotropin-releasing hormone neurones in the ewe: an anterograde tracing study. J Neuroendocrinol 2002; 2: 95-100.

177. Semaan SJ, Kauffman AS. Daily successive changes in reproductive gene expression and neuronal activation in the brains of pubertal female mice. Mol Cell Endocrinol 2015; : 84-97.

178. Butelman ER, Yuferov V, Kreek MJ. Kappa-Opioid Receptor/dynorphin System: Genetic and Pharmacotherapeutic Implications for Addiction. Trends Neurosci 2012; 10: 587-596.

179. Baile CA, McLaughlin CL, Buonomo FC, Lauterio TJ, Marson L, Della-Fera MA. Opioid peptides and the control of feeding in sheep. Fed Proc 1987; 1: 173-177.

180. Shimizu H, Shimomura Y, Negishi M, Kobayashi I, Kobayashi S. Dynorphin A (1-13), microinjected into the preoptic area, stimulates water intake in rats. Life Sci 1989; 1: 25-30.

181. Kim EM, Kotz CM, Welch CC, Grace MK, Billington CJ, Levine AS. Lactation decreases mRNA levels of opioid peptides in the arcuate nucleus of the rat. Brain Res 1997; 2: 303-308. 
182. Young WS,3rd, Lightman SL. Chronic stress elevates enkephalin expression in the rat paraventricular and supraoptic nuclei. Brain Res Mol Brain Res 1992; 1-2: 111-117.

183. Janecka A, Fichna J, Janecki T. Opioid receptors and their ligands. Curr Top Med Chem 2004; 1: 1-17.

184. Raynor K, Kong H, Chen Y, Yasuda K, Yu L, Bell GI, Reisine T. Pharmacological characterization of the cloned kappa-, delta-, and mu-opioid receptors. Mol Pharmacol 1994; 2: 330-334.

185. Waldhoer M, Bartlett SE, Whistler JL. Opioid receptors. Annu Rev Biochem 2004; : 953990.

186. Chen Y, Mestek A, Liu J, Yu L. Molecular cloning of a rat kappa opioid receptor reveals sequence similarities to the mu and delta opioid receptors. Biochem J 1993; Pt 3: 625-628.

187. Cox BM, Opheim KE, Teschemacher H, Goldstein A. A peptide-like substance from pituitary that acts like morphine. 2. Purification and properties. Life Sci 1975; 12: 1777-1782.

188. Goldstein A, Tachibana S, Lowney LI, Hunkapiller M, Hood L. Dynorphin-(1-13), an extraordinarily potent opioid peptide. Proc Natl Acad Sci U S A 1979; 12: 6666-6670.

189. Lowney LI, Gentleman SB, Goldstein A. A pituitary endorphin with novel properties. Life Sci 1979; 25: 2377-2384.

190. Goldstein A, Ghazarossian VE. Immunoreactive dynorphin in pituitary and brain. Proc Natl Acad Sci U S A 1980; 10: 6207-6210. 
191. Watson SJ, Akil H, Ghazarossian VE, Goldstein A. Dynorphin immunocytochemical localization in brain and peripheral nervous system: preliminary studies. Proc Natl Acad Sci U S A $1981 ; 2: 1260-1263$.

192. Khachaturian H, Watson SJ, Lewis ME, Coy D, Goldstein A, Akil H. Dynorphin immunocytochemistry in the rat central nervous system. Peptides 1982; 6: 941-954.

193. Foradori CD, Goodman RL, Lehman MN. Distribution of preprodynorphin mRNA and dynorphin-a immunoreactivity in the sheep preoptic area and hypothalamus. Neuroscience 2005; 2: $409-418$.

194. Peckys D, Landwehrmeyer GB. Expression of mu, kappa, and delta opioid receptor messenger RNA in the human CNS: a 33P in situ hybridization study. Neuroscience 1999; 4: 1093-1135.

195. Mansour A, Fox CA, Burke S, Meng F, Thompson RC, Akil H, Watson SJ. Mu, delta, and kappa opioid receptor mRNA expression in the rat CNS: an in situ hybridization study. J Comp Neurol 1994; 3: 412-438.

196. Weems PW, Witty CF, Amstalden M, Coolen LM, Goodman RL, Lehman MN. kappaOpioid Receptor Is Colocalized in GnRH and KNDy Cells in the Female Ovine and Rat Brain. Endocrinology 2016; 6: 2367-2379.

197. Quigley ME, Yen SS. The role of endogenous opiates in LH secretion during the menstrual cycle. J Clin Endocrinol Metab 1980; 1: 179-181. 
198. Shoupe D, Montz FJ, Lobo RA. The effects of estrogen and progestin on endogenous opioid activity in oophorectomized women. J Clin Endocrinol Metab 1985; 1: 178-183.

199. Casper RF, Alapin-Rubillovitz S. Progestins increase endogenous opioid peptide activity in postmenopausal women. J Clin Endocrinol Metab 1985; 1: 34-36.

200. Van Vugt DA, Bakst G, Dyrenfurth I, Ferin M. Naloxone stimulation of luteinizing hormone secretion in the female monkey: influence of endocrine and experimental conditions. Endocrinology 1983; 5: 1858-1864.

201. Whisnant CS, Goodman RL. Effects of an opioid antagonist on pulsatile luteinizing hormone secretion in the ewe vary with changes in steroid negative feedback. Biol Reprod 1988; 5: $1032-1038$.

202. Yang K, Haynes NB, Lamming GE, Brooks AN. Ovarian steroid hormone involvement in endogenous opioid modulation of LH secretion in mature ewes during the breeding and nonbreeding seasons. J Reprod Fertil 1988; 1: 129-139.

203. Masotto C, Sahu A, Dube MG, Kalra SP. A decrease in opioid tone amplifies the luteinizing hormone surge in estrogen-treated ovariectomized rats: comparisons with progesterone effects. Endocrinology 1990; 1: 18-25.

204. Walsh JP, Clarke IJ. Effects of central administration of highly selective opioid mu-, deltaand kappa-receptor agonists on plasma luteinizing hormone (LH), prolactin, and the estrogeninduced LH surge in ovariectomized ewes. Endocrinology 1996; 9: 3640-3648. 
205. Goodman RL, Coolen LM, Anderson GM, Hardy SL, Valent M, Connors JM, Fitzgerald

ME, Lehman MN. Evidence that dynorphin plays a major role in mediating progesterone negative feedback on gonadotropin-releasing hormone neurons in sheep. Endocrinology 2004; 6: 2959-2967.

206. Foradori CD, Goodman RL, Adams VL, Valent M, Lehman MN. Progesterone increases dynorphin a concentrations in cerebrospinal fluid and preprodynorphin messenger ribonucleic Acid levels in a subset of dynorphin neurons in the sheep. Endocrinology 2005; 4: 1835-1842.

207. Mostari P, Ieda N, Deura C, Minabe S, Yamada S, Uenoyama Y, Maeda K, Tsukamura H. dynorphin-kappa opioid receptor signaling partly mediates estrogen negative feedback effect on LH pulses in female rats. J Reprod Dev 2013; 3: 266-272.

208. Grachev P, Li XF, Kinsey-Jones JS, di Domenico AL, Millar RP, Lightman SL, O'Byrne KT. Suppression of the GnRH pulse generator by neurokinin B involves a kappa-opioid receptordependent mechanism. Endocrinology 2012; 10: 4894-4904.

209. Ruka KA, Burger LL, Moenter SM. Regulation of arcuate neurons coexpressing kisspeptin, neurokinin B, and dynorphin by modulators of neurokinin 3 and kappa-opioid receptors in adult male mice. Endocrinology 2013; 8: 2761-2771.

210. Nakahara T, Uenoyama Y, Iwase A, Oishi S, Nakamura S, Minabe S, Watanabe Y, Deura C, Noguchi T, Fujii N, Kikkawa F, Maeda K, Tsukamura H. Chronic peripheral administration of kappa-opioid receptor antagonist advances puberty onset associated with acceleration of pulsatile luteinizing hormone secretion in female rats. J Reprod Dev 2013; 5: 479-484. 
211. Schulz R, Wilhelm A, Pirke KM, Gramsch C, Herz A. Beta-endorphin and dynorphin control serum luteinizing hormone level in immature female rats. Nature 1981; 5843: 757-759.

212. Lopez JA, Bedenbaugh MN, McCosh RB, Weems PW, Meadows LJ, Wisman B, Coolen LM, Goodman RL, Hileman SM. Does Dynorphin Play a Role in the Onset of Puberty in Female Sheep?. J Neuroendocrinol 2016; 12: 10.1111/jne.12445.

213. Garthwaite J, Garthwaite G. Cellular origins of cyclic GMP responses to excitatory amino acid receptor agonists in rat cerebellum in vitro. J Neurochem 1987; 1: 29-39.

214. Garthwaite J, Charles SL, Chess-Williams R. Endothelium-derived relaxing factor release on activation of NMDA receptors suggests role as intercellular messenger in the brain. Nature 1988; 6197: 385-388.

215. Garthwaite J, Boulton CL. Nitric oxide signaling in the central nervous system. Annu Rev Physiol 1995; : 683-706.

216. Bredt DS, Glatt CE, Hwang PM, Fotuhi M, Dawson TM, Snyder SH. Nitric oxide synthase protein and mRNA are discretely localized in neuronal populations of the mammalian CNS together with NADPH diaphorase. Neuron 1991; 4: 615-624.

217. Chachlaki K, Garthwaite J, Prevot V. The gentle art of saying NO: how nitric oxide gets things done in the hypothalamus. Nat Rev Endocrinol 2017; 9: 521-535.

218. Crack PJ, Tetaz T, Smith AI. Purification, characterisation and distribution of ovine neuronal nitric oxide synthase. Comp Biochem Physiol B Biochem Mol Biol 1998; 4: 727-733. 
219. Vincent SR, Kimura H. Histochemical mapping of nitric oxide synthase in the rat brain. Neuroscience 1992; 4: 755-784.

220. Hashikawa T, Leggio MG, Hattori R, Yui Y. Nitric oxide synthase immunoreactivity colocalized with NADPH-diaphorase histochemistry in monkey cerebral cortex. Brain Res 1994; 2: 341-349.

221. Dufourny L, Skinner DC. Influence of estradiol on NADPH diaphorase/neuronal nitric oxide synthase activity and colocalization with progesterone or type II glucocorticoid receptors in ovine hypothalamus. Biol Reprod 2002; 3: 829-836.

222. Yamada K, Emson P, Hokfelt T. Immunohistochemical mapping of nitric oxide synthase in the rat hypothalamus and colocalization with neuropeptides. J Chem Neuroanat 1996; 3-4: 295316.

223. Calabrese V, Mancuso C, Calvani M, Rizzarelli E, Butterfield DA, Stella AM. Nitric oxide in the central nervous system: neuroprotection versus neurotoxicity. Nat Rev Neurosci 2007; 10: 766-775.

224. Branco LG, Soriano RN, Steiner AA. Gaseous mediators in temperature regulation. Compr Physiol 2014; 4: 1301-1338.

225. Rivier C. Role of hypothalamic corticotropin-releasing factor in mediating alcohol-induced activation of the rat hypothalamic-pituitary-adrenal axis. Front Neuroendocrinol 2014; 2: 221233. 
226. Routh VH, Hao L, Santiago AM, Sheng Z, Zhou C. Hypothalamic glucose sensing: making ends meet. Front Syst Neurosci 2014: 236.

227. Bellefontaine N, Hanchate NK, Parkash J, Campagne C, de Seranno S, Clasadonte J, d'Anglemont de Tassigny X, Prevot V. Nitric oxide as key mediator of neuron-to-neuron and endothelia-to-glia communication involved in the neuroendocrine control of reproduction. Neuroendocrinology 2011; 2: 74-89.

228. Srisawat R, Ludwig M, Bull PM, Douglas AJ, Russell JA, Leng G. Nitric oxide and the oxytocin system in pregnancy. J Neurosci 2000; 17: 6721-6727.

229. Donato J,Jr, Frazao R, Fukuda M, Vianna CR, Elias CF. Leptin induces phosphorylation of neuronal nitric oxide synthase in defined hypothalamic neurons. Endocrinology 2010; 11: 54155427.

230. Zimmerman CA, Lin YC, Leib DE, Guo L, Huey EL, Daly GE, Chen Y, Knight ZA. Thirst neurons anticipate the homeostatic consequences of eating and drinking. Nature 2016; 7622: 680-684.

231. Sutton AK, Pei H, Burnett KH, Myers MG,Jr, Rhodes CJ, Olson DP. Control of food intake and energy expenditure by Nos1 neurons of the paraventricular hypothalamus. J Neurosci 2014; 46: 15306-15318.

232. Sutton AK, Myers MG,Jr, Olson DP. The Role of PVH Circuits in Leptin Action and Energy Balance. Annu Rev Physiol 2016; : 207-221. 
233. Marsden PA, Schappert KT, Chen HS, Flowers M, Sundell CL, Wilcox JN, Lamas S, Michel T. Molecular cloning and characterization of human endothelial nitric oxide synthase. FEBS Lett 1992; 3: 287-293.

234. Forstermann U, Munzel T. Endothelial nitric oxide synthase in vascular disease: from marvel to menace. Circulation 2006; 13: 1708-1714.

235. Seidel B, Stanarius A, Wolf G. Differential expression of neuronal and endothelial nitric oxide synthase in blood vessels of the rat brain. Neurosci Lett 1997; 2-3: 109-112.

236. Stanarius A, Topel I, Schulz S, Noack H, Wolf G. Immunocytochemistry of endothelial nitric oxide synthase in the rat brain: a light and electron microscopical study using the tyramide signal amplification technique. Acta Histochem 1997; 4: 411-429.

237. Prevot V, Bouret S, Stefano GB, Beauvillain J. Median eminence nitric oxide signaling. Brain Res Brain Res Rev 2000; 1-2: 27-41.

238. Xu W, Charles IG, Moncada S, Gorman P, Sheer D, Liu L, Emson P. Mapping of the genes encoding human inducible and endothelial nitric oxide synthase (NOS2 and NOS3) to the pericentric region of chromosome 17 and to chromosome 7, respectively. Genomics 1994; 2: 419-422.

239. Cho HJ, Xie QW, Calaycay J, Mumford RA, Swiderek KM, Lee TD, Nathan C. Calmodulin is a subunit of nitric oxide synthase from macrophages. J Exp Med 1992; 2: 599-604.

240. Lirk P, Hoffmann G, Rieder J. Inducible nitric oxide synthase--time for reappraisal. Curr Drug Targets Inflamm Allergy 2002; 1: 89-108. 
241. Bredt DS, Snyder SH. Isolation of nitric oxide synthetase, a calmodulin-requiring enzyme. Proc Natl Acad Sci U S A 1990; 2: 682-685.

242. Stamler JS, Singel DJ, Loscalzo J. Biochemistry of nitric oxide and its redox-activated forms. Science 1992; 5090: 1898-1902.

243. Ignarro LJ. Signal transduction mechanisms involving nitric oxide. Biochem Pharmacol 1991; 4: 485-490.

244. Adak S, Santolini J, Tikunova S, Wang Q, Johnson JD, Stuehr DJ. Neuronal nitric-oxide synthase mutant (Ser-1412 --> Asp) demonstrates surprising connections between heme reduction, NO complex formation, and catalysis. J Biol Chem 2001; 2: 1244-1252.

245. Rameau GA, Tukey DS, Garcin-Hosfield ED, Titcombe RF, Misra C, Khatri L, Getzoff ED, Ziff EB. Biphasic coupling of neuronal nitric oxide synthase phosphorylation to the NMDA receptor regulates AMPA receptor trafficking and neuronal cell death. J Neurosci 2007; 13: 3445-3455.

246. Hayashi Y, Nishio M, Naito Y, Yokokura H, Nimura Y, Hidaka H, Watanabe Y. Regulation of neuronal nitric-oxide synthase by calmodulin kinases. J Biol Chem 1999; 29: 20597-20602.

247. Komeima K, Hayashi Y, Naito Y, Watanabe Y. Inhibition of neuronal nitric-oxide synthase by calcium/ calmodulin-dependent protein kinase IIalpha through Ser847 phosphorylation in NG108-15 neuronal cells. J Biol Chem 2000; 36: 28139-28143.

248. Moretto M, Lopez FJ, Negro-Vilar A. Nitric oxide regulates luteinizing hormone-releasing hormone secretion. Endocrinology 1993; 5: 2399-2402. 
249. Rettori V, Belova N, Dees WL, Nyberg CL, Gimeno M, McCann SM. Role of nitric oxide in the control of luteinizing hormone-releasing hormone release in vivo and in vitro. Proc Natl Acad Sci U S A 1993; 21: 10130-10134.

250. Bonavera JJ, Sahu A, Kalra PS, Kalra SP. Evidence that nitric oxide may mediate the ovarian steroid-induced luteinizing hormone surge: involvement of excitatory amino acids. Endocrinology 1993; 6: 2481-2487.

251. Aguan K, Mahesh VB, Ping L, Bhat G, Brann DW. Evidence for a physiological role for nitric oxide in the regulation of the LH surge: effect of central administration of antisense oligonucleotides to nitric oxide synthase. Neuroendocrinology 1996; 6: 449-455.

252. Pu S, Kalra PS, Kalra SP. Ovarian steroid-independent diurnal rhythm in cyclic GMP/nitric oxide efflux in the medial preoptic area: possible role in preovulatory and ovarian steroidinduced LH surge. J Neuroendocrinol 1998; 8: 617-625.

253. Pu S, Xu B, Kalra SP, Kalra PS. Evidence that gonadal steroids modulate nitric oxide efflux in the medial preoptic area: effects of N-methyl-D-aspartate and correlation with luteinizing hormone secretion. Endocrinology 1996; 5: 1949-1955.

254. Huang PL, Dawson TM, Bredt DS, Snyder SH, Fishman MC. Targeted disruption of the neuronal nitric oxide synthase gene. Cell 1993; 7: 1273-1286.

255. Eliasson MJ, Blackshaw S, Schell MJ, Snyder SH. Neuronal nitric oxide synthase alternatively spliced forms: prominent functional localizations in the brain. Proc Natl Acad Sci U S A 1997; 7: 3396-3401. 
256. Gyurko R, Leupen S, Huang PL. Deletion of exon 6 of the neuronal nitric oxide synthase gene in mice results in hypogonadism and infertility. Endocrinology 2002; 7: 2767-2774.

257. Herbison AE, Simonian SX, Norris PJ, Emson PC. Relationship of neuronal nitric oxide synthase immunoreactivity to GnRH neurons in the ovariectomized and intact female rat. J Neuroendocrinol 1996; 1: 73-82.

258. Al-Gubory KH, Locatelli A. Intracerebroventricular administration of copper-zinc superoxide dismutase inhibits pulsatile luteinizing hormone secretion in ovariectomized ewes. Neurosci Lett 1999; 3: 159-162.

259. McManus CJ, Valent M, Hardy SL, Goodman RL. Does nitric oxide act in the ventromedial preoptic area to mediate oestrogen negative feedback in the seasonally anoestrous ewe?. Reproduction 2007; 1: 137-145.

260. Brann DW, Mahesh VB. Endogenous excitatory amino acid involvement in the preovulatory and steroid-induced surge of gonadotropins in the female rat. Endocrinology 1991; 3: $1541-1547$.

261. Cheong RY, Czieselsky K, Porteous R, Herbison AE. Expression of ESR1 in Glutamatergic and GABAergic Neurons Is Essential for Normal Puberty Onset, Estrogen Feedback, and Fertility in Female Mice. J Neurosci 2015; 43: 14533-14543.

262. Scordalakes EM, Shetty SJ, Rissman EF. Roles of estrogen receptor alpha and androgen receptor in the regulation of neuronal nitric oxide synthase. J Comp Neurol 2002; 4: 336-344. 
263. Chachlaki K, Malone SA, Qualls-Creekmore E, Hrabovszky E, Munzberg H, Giacobini P, Ango F, Prevot V. Phenotyping of nNOS neurons in the postnatal and adult female mouse hypothalamus. J Comp Neurol 2017.

264. Sato S, Braham CS, Putnam SK, Hull EM. Neuronal nitric oxide synthase and gonadal steroid interaction in the MPOA of male rats: co-localization and testosterone-induced restoration of copulation and nNOS-immunoreactivity. Brain Res 2005; 1-2: 205-213.

265. Pinilla L, Gonzalez LC, Tena-Sempere M, Aguilar E. Nitro(w)-arginine methyl ester treatment delayed the onset of puberty in female rats. J Physiol Biochem 1998; 3: 135-139.

266. Kuiri-Hanninen T, Sankilampi U, Dunkel L. Activation of the hypothalamic-pituitarygonadal axis in infancy: minipuberty. Horm Res Paediatr 2014; 2: 73-80.

267. Caron E, Ciofi P, Prevot V, Bouret SG. Alteration in neonatal nutrition causes perturbations in hypothalamic neural circuits controlling reproductive function. J Neurosci 2012; 33: 1148611494.

268. Bouret SG, Draper SJ, Simerly RB. Formation of projection pathways from the arcuate nucleus of the hypothalamus to hypothalamic regions implicated in the neural control of feeding behavior in mice. J Neurosci 2004; 11: 2797-2805.

269. Messina A, Langlet F, Chachlaki K, Roa J, Rasika S, Jouy N, Gallet S, Gaytan F, Parkash J, Tena-Sempere M, Giacobini P, Prevot V. A microRNA switch regulates the rise in hypothalamic GnRH production before puberty. Nat Neurosci 2016; 6: 835-844. 
270. Bellefontaine N, Chachlaki K, Parkash J, Vanacker C, Colledge W, d'Anglemont de Tassigny X, Garthwaite J, Bouret SG, Prevot V. Leptin-dependent neuronal NO signaling in the preoptic hypothalamus facilitates reproduction. J Clin Invest 2014; 6: 2550-2559.

271. Reynoso R, Cardoso N, Szwarcfarb B, Carbone S, Ponzo O, Moguilevsky JA, Scacchi P. Nitric oxide synthase inhibition prevents leptin induced Gn-RH release in prepubertal and peripubertal female rats. Exp Clin Endocrinol Diabetes 2007; 7: 423-427. 


\section{CHAPTER 2}

\section{POTENTIAL IMPORTANCE OF THE NKB/NK3R SYSTEM IN THE PREOPTIC AREA FOR PUBERTY IN FEMALE SHEEP}

Michelle N. Bedenbaugh ${ }^{1}$, Richard B. McCosh ${ }^{1}$, Justin A. Lopez ${ }^{1}$, Catherine A. Rainey ${ }^{2}$, Ashley

N. Lindo ${ }^{1}$, Robert L. Goodman ${ }^{1}$, Stanley M. Hileman ${ }^{1}$

Department of Physiology, Pharmacology and Neuroscience, West Virginia University, Morgantown, $\mathrm{WV}^{1}$, Alderson Broaddus University, Phillippi, WV ${ }^{2}$

\section{Abbreviated Title: NKB/NK3R and puberty in female sheep}

Key Terms: puberty, GnRH, NKB, dynorphin, KOR 


\section{ABSTRACT}

Increased gonadotropin-releasing hormone (GnRH) secretion is critical for puberty onset. However, the neural mechanisms that underlie this increase are not completely understood. Neurokinin B (NKB) and dynorphin may play a role in regulating GnRH secretion during pubertal development, as senktide, an NKB receptor (NK3R) agonist, and nor-BNI, a kappaopioid receptor (KOR) antagonist, stimulate luteinizing hormone (LH) secretion in prepubertal ewes. However, where these effects occur within the hypothalamus is unknown. Our first aim was to examine whether senktide or nor-BNI would increase LH secretion when placed in the arcuate nucleus (ARC) or preoptic area (POA) of prepubertal ewes. Placement of senktidecontaining microimplants into either the ARC or POA significantly increased mean LH concentrations. In contrast, nor-BNI-containing microimplants had no effect on LH secretion when placed in either the ARC or the POA. Next, we investigated the influence of estradiol $\left(E_{2}\right)$ or age on NK3R expression in several hypothalamic areas, as well as ARC NKB and non-NKB neurons, specifically. Estradiol did not significantly alter NK3R cell number in any of the areas examined. However, there was a significant increase in the number of NK3R neurons in the POA of adult ewes compared to prepubertal ewes. In the ARC, a high percentage of both NKB and non-NKB neurons were associated with NK3R. In prepubertal ewes, a higher percentage of NKB neurons were associated with NK3R and exhibited more NK3R associations (membranebound NK3R receptors or axonal terminals containing NK3R) per cell compared to non-NKB neurons. However, neither $\mathrm{E}_{2}$ nor age altered the number of NK3R associations with neurons in the ARC. Finally, we also determined whether transitioning from a prepubertal to a postpubertal state would influence the percentage of GnRH neurons that colocalize with KOR. A high percentage of GnRH neurons in the POA, anterior hypothalamic area, and mediobasal 
hypothalamus colocalized with KOR, but there were no differences between prepubertal and postpubertal ewes. Further work will be necessary to determine how and where dynorphin is acting in prepubertal ewes to inhibit LH secretion. However, changes in the NKB/NK3R system, particularly within the POA, may play a role in the pubertal increase in LH secretion in ewes.

\section{INTRODUCTION}

Puberty is a transitional stage of development whereby an individual attains the ability to reproduce. While the endocrine events surrounding this complicated process have been researched extensively, the neural mechanisms that control the onset of puberty remain relatively unknown. In prepubertal female sheep, low concentrations of estradiol $\left(\mathrm{E}_{2}\right)$ strongly inhibit gonadotropin-releasing hormone (GnRH) secretion from the hypothalamus and thus luteinizing hormone (LH) release from the anterior pituitary. As female sheep grow and photoperiod conditions become permissive, the ability of $\mathrm{E}_{2}$ to inhibit GnRH and LH secretion decreases which leads to an increase in the release of both hormones (1). Estradiol plays an essential role in the inhibition of GnRH and LH secretion prior to puberty onset in sheep. However, the mechanisms through which this feedback is communicated to GnRH neurons remain unclear. Importantly, GnRH neurons do not contain estrogen receptor alpha (ER $\alpha)$, the estrogen receptor that is necessary for $\mathrm{E}_{2}$ to regulate $\mathrm{GnRH}$ secretion $(2,3)$. Therefore, other neuronal intermediates that do contain ER $\alpha$ must exist to communicate $E_{2}$ negative feedback to $\mathrm{GnRH}$ neurons.

Neurons that coexpress kisspeptin, neurokinin B (NKB), and dynorphin (KNDy neurons) in the arcuate nucleus (ARC) likely play an important role in mediating the effects of $E_{2}$ on $\mathrm{GnRH}$ 
neurons in sheep. The critical role of kisspeptin in puberty onset has been well-researched $(4,5)$. A very high percentage of KNDy neurons contain ER $\alpha$ (6), and our previous work suggests that kisspeptin may mediate $\mathrm{E}_{2}$ negative feedback prepubertally, as ovariectomy (OVX) increases kisspeptin-containing cell numbers in prepubertal, but not in postpubertal, female sheep (7). In contrast to kisspeptin, the role of NKB and dynorphin in the initiation of puberty has not been well characterized. Like kisspeptin, NKB is critical for reproduction in humans, as a mutation in either NKB or its receptor, NK3R, leads to infertility and hypogonadotropic hypogonadism (8). In adult female sheep, NKB has been implicated in the control of both surge and tonic LH secretion (9-12). The NK3R agonist, senktide, can also stimulate LH secretion in prepubertal ewes, and OVX causes increased NKB-containing cell numbers in both prepubertal and postpubertal females (7). Dynorphin is an endogenous opioid peptide that exerts its effects via binding to $\kappa$-opioid receptors (KOR) and has been suggested to mediate progesterone negative feedback in adult rats (13) and sheep (14). A recent report that GnRH neurons in adult rats and sheep colocalize with KOR indicates dynorphin may be directly communicating with GnRH neurons (15). In prepubertal sheep, GnRH neurons in the preoptic area (POA) also colocalize with KOR, and infusion of a KOR antagonist, nor-binaltorphimine (nor-BNI), into the lateral ventricle increases LH secretion in prepubertal, but not postpubertal, ewes (16). Importantly, while both NKB and dynorphin influence LH secretion in prepubertal female sheep, the mechanisms remain unclear.

In this study, we aimed to build upon our previous work and further elucidate the roles of NKB and dynorphin in the initiation of puberty in female sheep. To do this, we conducted experiments to determine whether NKB or dynorphin can act within the ARC or POA to influence LH secretion in prepubertal ewes, if the presence of $E_{2}$ or age of an animal would have 
an effect on hypothalamic NK3R expression, and if the transition from a prepubertal to a postpubertal state would affect the percentage of GnRH neurons colocalizing with KOR.

\section{MATERIALS AND METHODS}

\section{$\underline{\text { Animals }}$}

All animal experiments were conducted at the West Virginia University Farm Animal Research Facility in Morgantown, West Virginia. Procedures were approved by the West Virginia Animal Care and Use Committee and were performed in accordance with National Institutes of Health guidelines for use of animals in research. Ewes were purchased from a local producer and housed indoors where they received a commercial premium alfalfa-timothy cube food ration (crude protein $\geq 12 \%$, crude fat $\geq 18 \%$, crude fiber $\leq 32 \%$; Triple Crown Nutrition, Inc., Wayzata, MN, USA) and had free access to water and a mineral block supplement. Experiments involving prepubertal lambs were performed in early autumn (August) when lambs were 5-6 months of age. Experiments involving postpubertal ewes that were still under 1 year of age were performed in early winter (November and December), and experiments with adult anestrous ewes were performed in the summer (June and July). Ewes were housed two per pen (6.75 x 6.75 feet) on raised flooring with a clear view of all other sheep. Indoor lighting simulated the natural changes in day length.

\section{General Methods}

Surgical procedures

All surgeries were performed using aseptic techniques. Animals were anesthetized by i.v. injection of ketamine $(7 \mathrm{mg} / \mathrm{kg})$ and midazolam $(0.3 \mathrm{mg} / \mathrm{kg})$ and then maintained on $2 \%$ isoflurane. For OVX, ovarian vasculature was ligated and ovaries removed via a midventral 
incision. For neurosurgeries, bilateral chronic 18-gauge guide cannulae were stereotaxically inserted into either the POA or ARC, as previously described (17). Animals were treated preand postoperatively with analgesics (carprofen for both surgical procedures, in addition to gabapentin for neurosurgeries) and antibiotics (ampicillin for both surgical procedures, in addition to gentamycin for neurosurgeries). All veterinary drugs were purchased from Patterson Veterinary (Bessemer, AL, USA) with the exception of gabapentin which was produced locally (McCracken Pharmacy, Waynesburg, PA, USA). Animals were allowed to recover from surgical procedures for at least 1 week before experiments were conducted.

\section{Drug preparation, microimplantation, and blood collection procedures}

To investigate where the NK3R agonist, senktide (Tocris Bioscience, Ellisville, MO, USA), and the KOR antagonist, nor-BNI (Sigma-Aldrich, St. Louis, MO, USA), may be acting to influence LH secretion, these drugs were administered via microimplantation into the POA or ARC as has been previously described $(9,10,12)$. To construct microimplants, 22-gauge stainless steel tubing was cut to extend to the tip of the guide cannulae when placed in the ARC or $1.5 \mathrm{~mm}$ beyond the tip of the guide cannulae when placed in the POA. Microimplants did not extend beyond the tip of the guide cannulae in the ARC because empty microimplants extending further than the guide cannula can influence LH secretion in this area (12). Microimplants were filled with senktide or nor-BNI by tamping at least 60 times in crystalline drug. Empty microimplants were used as a control in all experiments. For every animal experiment, blood samples were collected every 12 min by jugular venipuncture for varying lengths of time (described below), placed in heparinized tubes, and plasma was stored at $-20^{\circ} \mathrm{C}$ until assayed for LH.

Tissue collection procedures 
For tissue collection, hypothalami were collected as described previously (18). Briefly, all sheep were heparinized (20,000 U) and euthanized using an intravenous overdose of sodium pentobarbital (Euthasol; Webster Veterinary, Devens, MA, USA). Heads were removed and perfused via carotid arteries with 4 L (lambs) or 6 L (adult ewes) of $4 \%$ paraformaldehyde in 0.1 M phosphate buffer (PB; pH 7.4) containing 0.1\% sodium nitrite. Blocks of tissue containing the POA and hypothalamus were removed and stored in a 4\% paraformaldehyde solution for $24 \mathrm{~h}$ at $4^{\circ} \mathrm{C}$ and transferred to $20 \%$ sucrose until sectioned. Frozen coronal sections were cut with a freezing microtome and stored in cryopreservative until the time of immunohistochemical staining.

\section{Experiment 1: Does senktide or nor-BNI placed in the ARC affect LH secretion in}

\section{prepubertal ewes?}

Bilateral guide cannulae were inserted into the ARC of 17 ovary-intact prepubertal ewes. Ewes were randomly assigned to receive senktide-containing $(n=6)$, nor-BNI-containing $(n=6)$ or empty ( $n=5)$ microimplants. Blood samples were collected every 12 min for 8 hrs (4 hrs before insertion of microimplants and 4 hrs after). At the end of the sampling period, microimplants were removed and replaced with obturators.

\section{Experiment 2: Does senktide or nor-BNI placed in the POA affect LH secretion in}

\section{prepubertal ewes?}

Bilateral guide cannulae were inserted into the POA of 8 ovary-intact prepubertal ewes. Ewes were randomly assigned to receive senktide-containing, nor-BNI-containing, or empty microimplants. Blood samples were collected every $12 \mathrm{~min}$ for $36 \mathrm{~min}$ before and 4 hrs after 
microimplant insertion. At the end of the sampling period, microimplants were removed and replaced with obturators. These procedures were repeated twice at weekly intervals so that each animal received all treatments in a cross-over design.

Experiment 3: Does the presence of $E_{2}$ in prepubertal ewes or age affect NK3R expression in the POA and hypothalamus?

For this experiment, immunohistochemistry was used to detect NK3R-immunoreactive (IR) neurons and fibers in the POA and hypothalamus of prepubertal ewes that were ovariectomized at approximately 5 months of age and were randomly assigned to receive a subcutaneous $1-\mathrm{cm}$ long Silastic (inner diameter $0.34 \mathrm{~cm}$, outer diameter $0.45 \mathrm{~cm}$; Dow Corning Corp., Midland, MI, USA) implant containing crystalline $\mathrm{E}_{2}$ (Sigma-Aldrich, St. Louis, MO, USA) $(\mathrm{OVX}+\mathrm{E} ; \mathrm{n}=4)$ or no implant (OVX; $\mathrm{n}=4)$ and adult ewes that were ovariectomized during the non-breeding season and did not receive an $\mathrm{E}_{2}$ implant (Adult; $\mathrm{n}=3$ ). Blood samples were collected from all ewes every 12 min for 4 hrs. Hypothalamic tissue was collected immediately following blood sampling procedures. Frozen coronal sections $(30 \mu \mathrm{m})$ were cut with a freezing microtome, collected in 5 series (150 $\mu \mathrm{m}$ apart) and stored in cryopreservative until the time of immunohistochemical staining.

For immunohistochemistry, 3 to 4 comparable tissue sections were selected for all ewes from the following areas: POA (3), paraventricular nucleus (PVN, 4), retrochiasmatic area (RCh, 4), and middle-caudal ARC (4). On day 1 of the protocol, sections were washed 4x5 min in $0.1 \mathrm{M}$ phosphate-buffered saline (PBS) to remove excess cryoprotectant and stored overnight in PBS at $4^{\circ} \mathrm{C}$. The next day, sections were washed $4 \times 5$ min in PBS, placed in $1 \% \mathrm{H}_{2} \mathrm{O}_{2}$ for $10 \mathrm{~min}$, and subsequently washed $4 \times 5$ min in PBS. Tissue was then incubated for at least $1 \mathrm{~h}$ in a blocking 
solution containing PBS, 0.4\% Triton X-100 (PBSTX; Sigma-Aldrich, St. Louis, MO, USA) and 4\% normal goat serum (NGS; Jackson ImmunoResearch Laboratories, Inc., West Grove, PA, USA) in PBS. Sections were incubated in a solution containing rabbit anti-NK3R antiserum (Cat.\#300-102; 1:5,000, RRID: AB_2287128; Novus Biologicals, Littleton, CO, USA) in PBSTX and 4\% NGS for $16 \mathrm{~h}$. After incubation with the primary antibody, sections were washed and then incubated in a solution containing biotinylated goat anti-rabbit IgG (1:400; Vector Laboratories, Burlingame, CA, USA), PBSTX, and 4\% NGS for $1 \mathrm{~h}$. The sections were washed and incubated in a solution containing streptavidin horseradish-peroxidase conjugate (Vectastain Elite ABC, 1:600; Vector Laboratories) for $1 \mathrm{~h}$. Sections were then washed and incubated in a solution containing 3,3-diaminobenzidine (DAB; $0.2 \mathrm{mg} / \mathrm{ml}$; Sigma-Aldrich) and hydrogen peroxide (0.012\%; Sigma-Aldrich) in PBS for $10 \mathrm{~min}$. The sections were washed, mounted on Superfrost microscope slides (Fisher Scientific, Pittsburgh, PA, USA), and coverslipped using Eukitt Mounting Reagent (Fisher Scientific). The total number of NK3R neurons in each area was counted using a VS120 bright-field microscope (Olympus, Tokyo, Japan).

Experiment 4: Does the presence of $E_{2}$ in prepubertal ewes or age affect the number of NK3R-positive associations on NKB and non-NKB cells in the ARC?

Tissue sections from the same animals that were used in experiment 3 were used for this experiment. To detect NKB cells, non-NKB cells, and NK3R associations with the cellular membrane, 4 comparable sections from the middle-caudal ARC of every animal were selected. Please note that the term "association" in this article refers to histochemically-labeled NK3R puncta (either membrane-bound NK3R receptors or axonal terminals containing NK3R) that are 
in direct contact with a cell body. Due to the nature of NK3R staining within the ARC, it was not possible to definitively differentiate between the two. The first two days of the protocol were identical to the immunohistochemical procedure described above until tissue was placed in blocking solution that contained 20\% NGS instead of 4\% NGS. Tissue sections were placed in a solution containing rabbit anti-NK3R antiserum (Cat.\#300-102; 1:20,000, AB_2287128; Novus Biologicals) in PBSTX and 4\% NGS for $16 \mathrm{~h}$. After incubation with the primary antibody, sections were incubated in a solution containing biotinylated goat anti-rabbit IgG and a solution containing streptavidin horseradish-peroxidase conjugate as stated in the protocol above. Sections were then washed and incubated for $10 \mathrm{~min}$ in biotinylated tyramine (TSA; 1:250; Perkin Elmer, Waltham, MA, USA) in PBS containing 3\% $\mathrm{H}_{2} \mathrm{O}_{2}$ per $1 \mathrm{~mL}$ of solution. After washing, sections were incubated in a solution containing Alexa 555-streptavidin (1:200, Life Technologies, Carlsbad, CA, USA) for $1 \mathrm{~h}$ followed by washes in PBS. Sections were then incubated in rabbit anti-NKB antiserum (Cat.\#H-046-26; 1:250, RRID: AB_2716809; Phoenix Pharmaceuticals Inc., Burlingame, CA, USA ) in PBSTX, and 4\% NGS for $16 \mathrm{~h}$. The following day, sections were incubated in DyLight green goat anti-rabbit (1:200; Fisher Scientific, Hampton, NH, USA) for $1 \mathrm{~h}$ and washed. Sections were then incubated in neurotrace 640/660 deep red fluorescent Nissl (1:500; Fisher Scientific) for 2 h so that non-NKB cells could be visualized. Sections were washed, mounted on Superfrost slides (Fisher Scientific), coverslipped using Gelvatol and stored in the dark at $4^{\circ} \mathrm{C}$ until analysis.

The number of NK3R associations on NKB and non-NKB neurons was determined by capturing images of $10 \mathrm{NKB}$ and 10 non-NKB neurons in the ARC of each animal using a LSM 510 laser scanning confocal system (Zeiss, Thornwood, NY, USA) on a Zeiss Axio Image Z1 upright microscope with a Plan Apochromat x 63/1.4 oil objective. Confocal z-stacks of optical 
sections were taken at $1 \mu \mathrm{m}$ intervals through each neuron analyzed. The number of NK3R associations on neuronal cell bodies was analyzed using ZEN software (Zeiss). Because NK3R associations were counted through the entire z-stack, markers were placed on each individual association to ensure that no contacts were counted more than once. Orthogonal views were used to confirm that associations were touching the cell in all planes.

\section{Experiment 5: Does the pubertal transition affect colocalization between GnRH neurons}

\section{and KOR?}

For this experiment, 5 prepubertal ewes that were approximately 6 months of age and 5 postpubertal ewes that were approximately 10 months of age were used. All animals were ovariectomized and received a 1-cm long E2 implant. Prepubertal ewes were ovariectomized and received a 1-cm long $E_{2}$ implant at approximately 5 months of age. Two weeks after ovariectomy, blood samples were collected every $12 \min$ for 4 hrs and hypothalamic tissue was collected immediately thereafter. Ewes in the postpubertal group were ovariectomized and received a 1-cm long $E_{2}$ implant at approximately 8 months of age. Once these ewes reached 10 months of age, a time when ewes would be considered to be postpubertal, blood samples were collected every 12 min for 4 hrs and hypothalamic tissue was collected immediately following the collection of the last blood sample. Frozen coronal sections $(45 \mu \mathrm{m})$ were cut with a freezing microtome, collected in 5 series (225 $\mu \mathrm{m}$ apart) and stored in cryopreservative until the time of immunohistochemical staining.

To determine if the pubertal transition alters the percentage of GnRH neurons that colocalize with KOR, dual-label immunofluorescence was used to detect GnRH and KOR. Every other hemisection from one complete series of sections throughout the POA and mediobasal 
hypothalamus (MBH) from each animal was used. Day 1 of the staining protocol was identical to the procedures described above for experiments 3 and 4 . On day 2, a heat-mediated antigen retrieval protocol was used as has been previously described (15). The remainder of the staining procedure was the same as was specified above for experiment 4 with a few exceptions. Tissue sections were incubated in a solution containing mouse anti-KOR-1 (D-8) antiserum (Cat\#sc374479; 1:250, RRID: AB_10989571; Santa Cruz Biotechnology, Dallas, TX, USA) at the end of day 2 and rabbit anti-GnRH antiserum (cat\#20075; 1:400, RRID: AB_572248; Immunostar, Hudson, WI, USA) at the end of day 3. Biotinylated goat anti-mouse antiserum was used instead of biotinylated goat anti-rabbit antiserum at the beginning of day 3. Neurotrace 640/660 was not used in this staining protocol.

To determine the percentage of GnRH neurons throughout the POA and hypothalamus that were colocalized with KOR, sections were visualized using a fluorescent microscope (VS120, Olympus). The total number of GnRH neurons, as well as the percentage of GnRH neurons that colocalized with KOR, were recorded for each animal.

\section{$\underline{\text { Data Analysis }}$}

Assays

Concentrations of LH were measured in duplicate by radioimmunoassay as described previously (19) using reagents provided by the National Hormone and Peptide Program (Torrance, CA, USA). Assays used 100 to $200 \mu \mathrm{L}$ of plasma and sensitivity averaged 0.08 ng/tube (NIHS24) with intra- and interassay coefficients of variations being $10.9 \%$ and $14.9 \%$ respectively. 


\section{Statistical Analysis}

Similar to previous work (20), three criteria were used to identify an LH pulse; (1) a peak must occur within two samples of the previous nadir; (2) the amplitude must be greater than the sensitivity of the LH assay; and (3) the LH concentrations at the peak must exceed the $95 \%$ confidence limits (based on overall assay variability) of the concentrations at both the preceding and subsequent nadir. In experiments 1 and 2, mean LH and LH pulse amplitudes were compared using repeated measures ANOVA and LH pulse frequency was compared by Friedman repeated measures ANOVA. In experiment 3, mean NK3R cell numbers were compared using a one-way ANOVA. Significant differences among groups were determined by a test of least significant differences. In experiment 4, the number of NK3R associations was transformed to the square root and compared using a one-way ANOVA. The percentage of cells with NK3R associations was compared using a one-way ANOVA. Significant differences among groups were determined by a test of least significant differences. In experiments 3 and 4 , when determining the effect of age, the prepubertal OVX and OVX+E groups were combined because no significant differences were observed between these two groups. Mean NK3R cell numbers and the number of NK3R associations were compared by t-test. The percentage of cells with NK3R associations was analyzed via chi-squared analysis. For experiment 5, the percentage of GnRH neurons that colocalized with KOR was analyzed via chi-squared analysis. $\mathrm{P}<0.05$ was considered statistically significant.

\section{RESULTS}

\section{Experiment 1: Does senktide or nor-BNI placed in the ARC affect LH secretion in}

\section{prepubertal ewes?}


Sixteen of the seventeen ewes had properly-placed guide cannulae in the ARC (Figure 1A). In the one ewe with improper guide cannula placement, one guide cannula was located within the third ventricle. Data from this animal were excluded from analysis. Ewes that received senktide-containing microimplants exhibited significantly $(\mathrm{P}<0.01)$ increased mean LH concentrations $(8.0 \pm 0.5 \mathrm{ng} / \mathrm{ml})$ compared to ewes that received empty microimplants $(1.9 \pm 0.2$ ng/ml; Figure 1B, 1C left panel). However, this increase in LH secretion after treatment with senktide in the ARC was generally not episodic (Figure 1C, middle panel). Thus, this agonist had no effect on LH pulse frequency or LH pulse amplitude (Figure 1B). Placement of nor-BNIcontaining microimplants into the ARC had no effect on mean LH concentrations, LH pulse frequency or LH pulse amplitude when compared to ewes that received empty microimplants (Figure 1B, 1C right panel).

\section{Experiment 2: Does senktide or nor-BNI placed in the POA affect LH secretion in prepubertal ewes?}

Seven of the eight ewes had properly-placed guide cannulae in the POA (Figure 2A); placement in the remaining ewe was rostral to the POA and data from this animal were excluded in analyses. Placement of senktide-containing microimplants into the POA significantly increased $(\mathrm{P}<0.05)$ mean $\mathrm{LH}$ concentrations compared to empty microimplants $(3.1 \pm 0.7 \mathrm{ng} / \mathrm{ml}$ vs. $1.9 \pm 0.3 \mathrm{ng} / \mathrm{ml}$; Figure $2 \mathrm{~B}$ ). Treatment with senktide-containing microimplants had no effect on LH pulse frequency or LH pulse amplitude compared to treatment with empty microimplants (Figure 2B). Placement of nor-BNI-containing microimplants into the POA had no effect on mean LH concentrations, LH pulse frequency, or LH pulse amplitude when compared to empty microimplants (Figure 2B). Although there was a significant increase in mean LH secretion in 
response to senktide, the response wasvariable with only some ewes (4 of the 7) appearing to respond, and this response did not correlate with the placement of guide cannulae. Luteinizing hormone secretory profiles from a ewe that appeared to respond and a ewe that appeared not to respond to senktide treatment, as well as the lack of response to nor-BNI in both ewes, are shown in Figure 2C.

\section{Experiment 3: Does the presence of $E_{2}$ in prepubertal ewes or age affect NK3R expression} in the POA and hypothalamus?

In the POA of adult OVX non-breeding season ewes, there was a greater $(\mathrm{P}<0.01)$ number of NK3R neurons (248.3 \pm 34.7$)$ compared to either OVX $(71.0 \pm 19.0)$ or OVX+E $(108.3 \pm 28.7)$ prepubertal ewes (Figure 3A, B). In contrast, in the ARC there was a greater $(\mathrm{P}<0.05)$ number of NK3R neurons in OVX and OVX+E (11.9 \pm 1.3$)$ prepubertal ewes compared to adult ewes (4.3 \pm 0.7; Figure 3C). However, in comparison to other hypothalamic areas, very few cells with cytoplasmic NK3R staining were observed in the ARC of each animal. In the RCh, there was a trend $(\mathrm{P}=0.06)$ for there to be more NK3R neurons in prepubertal OVX and OVX+E ewes (143.5 \pm 12.2$)$ compared to adult ewes $(94.7 \pm 11.7)$. There were no differences among treatment groups in the number of NK3R neurons present in the PVN (OVX $=113.3 \pm 17.0$; $\mathrm{OVX}+\mathrm{E}=137.5 \pm 31.4$; Adult $=125.0 \pm 21.1$.

\section{Experiment 4: Does the presence of $E_{2}$ in prepubertal ewes or age affect the number of NK3R-positive associations on NKB and non-NKB cells in the ARC?}

In all ewes, regardless of treatment, a high percentage of both NKB and non-NKB cells were associated with NK3R (Figure 4A). In OVX and OVX+E prepubertal ewes, a higher $(\mathrm{P}<0.05)$ 
percentage of NKB cells were associated with NK3R than non-NKB cells (OVX: $97.5 \pm 1.7 \%$ vs. $72.5 \pm 8.3 \%$; OVX+E: $95.0 \pm 1.9 \%$ vs. $76.0 \pm 10.0 \%$; Figure $4 \mathrm{~B}$ ). In contrast, there was no difference in the percentage of NKB cells that were associated with NK3R compared to nonNKB cells in adult ewes ( $96.7 \pm 2.9 \%$ vs. $86.7 \pm 11.6 \%)$. There was no effect of $\mathrm{E}_{2}$ or age on the percentage of NKB or non-NKB cells that were associated with NK3R (Figure 4B). When comparing the number of NK3R associations onto NKB and non-NKB cells, NKB cells had significantly more $(\mathrm{P}<0.01)$ NK3R associations than non-NKB cells in prepubertal OVX and OVX+E ewes (OVX: $5.3 \pm 0.4$ vs. $1.7 \pm 0.3$ associations; OVX+E: $4.1 \pm 0.5$ vs. $2.0 \pm 0.4$ associations; Figure 4C). There was no difference in the number of NK3R associations onto NKB and non-NKB cells in adult ewes ( $3.7 \pm 0.9$ vs. $3.3 \pm 0.4$ associations). There was also no effect of $E_{2}$ on the number of NK3R associations onto NKB or non-NKB cells (Figure 4C). Age did not have an effect on the number of NK3R associations onto NKB cells. However, nonNKB cells in adult ewes had significantly more $(\mathrm{P}<0.05)$ NK3R associations than prepubertal ewes ( $3.3 \pm 0.4$ vs. $1.8 \pm 0.4$ associations; Figure 4 C).

\section{Experiment 5: Does the pubertal transition affect colocalization between GnRH neurons and KOR?}

An example of dual immunofluorescence for KOR and GnRH is shown in Figure 5. In each the POA, AHA, and MBH, a high percentage of GnRH neurons colocalized with KOR. However, there were no differences in the percentage of GnRH neurons colocalized with KOR between prepubertal and postpubertal ewes in the POA ( $80.1 \pm 4.3 \%$ vs. $77.4 \pm 3.4 \%$ ), AHA $(86.4 \pm 3.1 \%$ vs. $74.7 \pm 7.0 \%)$ or $\mathrm{MBH}(69.6 \pm 4.7 \%$ vs. $77.0 \pm 9.5 \%)$. 


\section{DISCUSSION}

An increase in GnRH and LH secretion is critical for the initiation of puberty. However, the neural mechanisms that underlie this increase in secretion are not completely understood. In the present study, we report for the first time that senktide placement into either the ARC or POA of prepubertal ewes resulted in an increase in mean LH concentrations. In contrast, administration of the KOR antagonist, nor-BNI, in the ARC or POA had no significant effect on LH secretion. The number of NK3R-IR neurons was increased in the POA and decreased in the ARC of adult ewes compared to prepubertal ewes. However, $E_{2}$ treatment in prepubertal ewes did not influence the number of NK3R-IR neurons in any of the areas studied. In the ARC of both prepubertal and adult ewes, a high percentage of both NKB and non-NKB neurons were associated with NK3R. In prepubertal ewes, NK3R immunoreactivity was associated with a higher percentage of NKB neurons than non-NKB neurons, and NKB neurons also exhibited more NK3R associations on average. However, E2 had no effect on either of these endpoints. In contrast to prepubertal ewes, NKB neurons did not exhibit more NK3R associations than nonNKB neurons in adult ewes. Finally, while a high percentage of GnRH neurons do colocalize with KOR in the POA and hypothalamus of ewes, this percentage does not appear to change as ewes transition from a prepubertal to a postpubertal state.

Previously, our laboratory has shown that intravenous administration of senktide stimulates LH secretion in prepubertal ewes (7). This is consistent with other studies showing that senktide stimulates LH secretion in prepubertal female rats (21) and juvenile male monkeys (22). We also previously showed that senktide administration caused an increase in LH secretion when placed in the POA or ARC of adult ewes (9). Our study extends these observations to prepubertal animals because it was not previously known where in the brain senktide may act to 
stimulate LH secretion in prepubertal ewes and whether age may influence this response. Placement of senktide into the ARC caused a significant increase in mean LH but not LH pulse frequency. Interestingly, this increase was similar in magnitude and appearance to that observed in our previous work using adult ewes (peak LH concentrations: $5.8 \pm 2.5 \mathrm{ng} / \mathrm{ml}$ ) when senktide was placed within the ARC (9). Consistent with the findings of Porter et al. (9), we also observed a significant increase in mean LH concentrations, but not LH pulse frequency, when senktide was placed in the POA. However, we observed a relatively small increase in comparison to that observed previously in adult ewes (peak LH concentrations: $22.4 \pm 9.1 \mathrm{ng} / \mathrm{ml}$ ) (9) indicating that changes in responsivity to NKB may occur in the POA as ewes mature. Similar trends have also been reported in female rats, where peripubertal females exhibited increased LH concentrations compared to juvenile females that received senktide ICV in the lateral ventricle (21). Therefore, developmental changes in the NKB/NK3R neurocircuitry, particularly within the POA, may be occurring as ewes mature. The mechanism underlying a possible change in sensitivity to NKB is not clear but may involve changes in NK3R expression.

To determine if changes in NK3R expression might reflect potential age-associated changes in the response to senktide, we assessed expression of NK3R throughout the POA and hypothalamus in prepubertal and adult ewes. To our knowledge, this is the first report comparing the number of NK3R-IR neurons in several areas of the brain between prepubertal and adult animals. In the PVN, there were no differences in the number of NK3R neurons between prepubertal and adult ewes, and there was only a trend for there to be an increased number of NK3R neurons in the RCh of prepubertal ewes. However, in the POA, adult ewes exhibited an increased number of NK3R neurons compared to prepubertal ewes. This provides a possible explanation for the differences in the response to senktide placement in the POA in our 
current work compared to the response in adult ewes described previously (9). The identity of the neurons which respond to senktide are unknown, but do not appear to include GnRH neurons (23). Based on this, we would suggest that changes in response to NKB within the POA may be important for puberty onset. However, it is important to emphasize that this is not the only aspect of the KNDy system that is likely changing in an age-associated manner. The number of kisspeptin neurons in the POA and ARC of rats are known to increase during the pubertal transition (24). Postpubertal increases in the number of kisspeptin neurons also occur in the POA of mice (25) and the ARC of sheep (7). In mice, the percentage of GnRH neurons depolarized by kisspeptin also increases as these animals mature from a juvenile to an adult state (26). Neurokinin B synthesis and secretion may also occur as ewes mature, but our previous work did not find an age-associated change in the number of NKB neurons in the ARC as ewes transitioned from a prepubertal to a postpubertal state (7).

In the ARC, while there was a significantly greater number of NK3R neurons present in prepubertal ewes compared to adult ewes, NK3R neurons were difficult to identify due to the punctate nature of the staining. Developmental changes to the NK3R system have also been reported in the ARC of female rats where NK3R mRNA abundance increased in pubertal females compared to late-infantile females (21). In our study, the difference in NK3R cell numbers between prepubertal and adult ewes was relatively small, and thus it is difficult to determine what functional significance, if any, this change in cell numbers would have in the initiation of puberty in ewes.

The presence of $E_{2}$ in prepubertal ewes had no effect on the number of NK3R neurons in any of the areas studied. Alternatively, both kisspeptin and NKB expression in the ARC is decreased in the presence of $E_{2}$ in prepubertal ewes $(7,16,27)$. Therefore, while $E_{2}$ may inhibit NKB 
expression in prepubertal ewes, it does not appear to have a significant effect on the number of cells that express NK3R. Thus, the changes we observed in NK3R expression between prepubertal and adult ewes are likely age-related and not dependent on $\mathrm{E}_{2}$. Together, this suggests that $\mathrm{E}_{2}$ influences the synthesis and release of NKB rather than the response to NKB. While $E_{2}$ did not affect the total number of ARC NK3R neurons in prepubertal ewes, it could have an effect on specific subpopulations of neurons within the ARC, making the detection of differences difficult $(23,28,29)$. Thus, we investigated NK3R expression in both NKB and nonNKB populations. In the present study, a high percentage (70-95\%) of both NKB and non-NKB neurons in the ARC of prepubertal and adult ewes were associated with NK3R. This high degree of colocalization is in accordance to what has been previously reported in adult ewes in the luteal phase of the estrous cycle (23). In our prepubertal ewes, a higher percentage of NKB neurons were associated with NK3R and exhibited more NK3R associations per cell than non-NKB neurons, underscoring the tremendous amount of reciprocity amongst KNDy neurons. However, approximately 75\% of non-NKB neurons analyzed were also associated with NK3R. Moreover, in contrast to prepubertal ewes, NKB neurons did not exhibit more NK3R associations than nonNKB neurons in adult ewes, suggesting that differences in NK3R associations between prepubertal and adult ewes are largely due to changes in non-NKB neurons. Like NKB, these efferent neurons may play a role in the control of reproduction. However, neurons of the ARC are involved in several physiological processes and, as such, these non-NKB neurons could also be involved in the control of other homeostatic mechanisms, including temperature regulation $(30,31)$ and metabolism (32). Further studies are needed to determine the identity of these nonNKB neurons in the ARC and if they play a role in the initiation of puberty and/or serve other functions. Similar to what was found with the number of NK3R neurons, the percentage of cells 
associated with NK3R or the number of NK3R associations was not influenced by the presence of $E_{2}$. In addition, there were no differences in the percentage of cells associated with NK3R or the number of NK3R associations between prepubertal and adult ewes. Thus, NK3R expression in cells of the ARC appears to remain relatively constant in prepubertal ewes regardless of whether $\mathrm{E}_{2}$ is present or as ewes age.

In contrast to the increase in LH secretion that was observed with senktide, placement of norBNI into either the POA or ARC of prepubertal ewes had no effect on LH secretion. When norBNI is infused into the lateral ventricle, mean LH concentrations and LH pulse frequency are increased in ewes of a prepubertal, but not postpubertal, age (16). A high percentage of kisspeptin neurons in the POA and ARC, as well as GnRH neurons in the POA and hypothalamus, of ewes colocalize with KOR raising the possibility that dynorphin could act either indirectly or directly to inhibit GnRH secretion $(15,16)$. Therefore, we hypothesized that dynorphin would act in the POA and/or ARC of prepubertal ewes to block GnRH release. However, we found that blocking KORs separately in the POA or ARC of prepubertal ewes did not significantly influence LH secretion. Redundancy may exist with regard to dynorphin input and that blockade of KOR in multiple locations in the brain is required to affect LH secretion in prepubertal ewes. Dynorphin may also be binding to KORs in areas outside of the POA or ARC to inhibit LH secretion. In addition to being present in the POA and ARC, KOR is found in several other areas of the hypothalamus in sheep (15), rats (15, 33), mice (34), and humans (35). Future studies are needed to parse out the exact location(s) wherein dynorphin is acting to inhibit LH secretion in prepubertal ewes.

Previous studies from our lab revealed that a high percentage of GnRH neurons in the POA of prepubertal ewes colocalize with KOR, and the presence of $\mathrm{E}_{2}$ causes a modest but significant 
decrease in the percentage of colocalization (16). However, whether the percentage of colocalization between GnRH and KOR changes as ewes transition from a prepubertal to a postpubertal state was not determined in our previous work. In the present study, a high percentage of GnRH neurons in the POA and hypothalamus colocalized with KOR, but there were no significant differences between prepubertal and postpubertal ewes. Therefore, while the presence of KOR in GnRH neurons indicates dynorphin may be able to directly influence GnRH secretion, the percentage of colocalization between GnRH and KOR does not seem to be influenced by $\mathrm{E}_{2}$ in prepubertal ewes or change as ewes transition from a prepubertal to a postpubertal state. However, a lack of changes in the percent colocalization between GnRH and KOR does not mean that other functionally important changes caused by $\mathrm{E}_{2}$ or maturation are not occurring. The number of KORs present within a GnRH neuron may change in the presence of $\mathrm{E}_{2}$ or as ewes mature. One limitation to using immunohistochemistry is the binary nature of the technique in that a cell is either positive for KOR or it is not. Thus, using an approach that would determine actual sensitivity of the cell to dynorphin may be necessary to address this question. Such an approach is not currently available in sheep.

In summary, placement of nor-BNI into either the POA or ARC had no significant effect on LH secretion, and no age-related changes in KOR expression in GnRH neurons were observed. Therefore, the site of the inhibitory action of dynorphin in prepubertal lambs remains to be determined. In contrast, senktide can act in both the POA and ARC of prepubertal ewes to stimulate LH secretion as it does in adult ewes. However, the response to senktide treatment in the POA is markedly smaller than what has been previously reported in adult ewes, indicating that changes in response to NKB, specifically in the POA, may play an important role in the initiation of puberty in sheep. The fact that an increase in the number of NK3R neurons was 
observed in the POA but not in other areas of the hypothalamus of adult sheep compared to prepubertal sheep serves as additional evidence that the POA may be an important area controlling the initiation of puberty in ewes. Therefore, while it is clear NKB can act in the POA and ARC of prepubertal ewes to influence LH secretion, these data point to the POA as an important site for puberty-related changes.

\section{ACKNOWLEDGEMENTS}

We thank Dr. Miroslav Valent and Gail Sager for their assistance with radioimmunoassays and animal surgeries. We would also like to thank Dr. Margaret Minch and Dr. Jennifer Fridley for veterinary care, and Dr. Al F. Parlow and the National Hormone and Peptide Program for reagents used to measure LH. Imaging experiments and analysis were performed in the West Virginia University Microscope Imaging Facility which is supported by the Mary Babb Randolph Cancer Center and National Institutes of Health Grants P20 RR016440 and P30 RR032138. This work was supported by the National Institute of Food and Agriculture, U.S. Department of Agriculture grant 2013-67015-20956 (SMH) and NIH grant P20GM103434 to the West Virginia IDeA Network for Biomedical Research Excellence.

\section{REFERENCES}

1. Foster DL, Ryan KD. Endocrine mechanisms governing transition into adulthood: a marked decrease in inhibitory feedback action of estradiol on tonic secretion of luteinizing hormone in the lamb during puberty. Endocrinology 1979; 4: 896-904. 
2. Dorling AA, Todman MG, Korach KS, Herbison AE. Critical role for estrogen receptor alpha in negative feedback regulation of gonadotropin-releasing hormone mRNA expression in the female mouse. Neuroendocrinology 2003; 4: 204-209.

3. Lehman MN, Ebling FJ, Moenter SM, Karsch FJ. Distribution of estrogen receptorimmunoreactive cells in the sheep brain. Endocrinology 1993; 2: 876-886.

4. Seminara SB, Messager S, Chatzidaki EE, Thresher RR, Acierno JS,Jr, Shagoury JK, BoAbbas Y, Kuohung W, Schwinof KM, Hendrick AG, Zahn D, Dixon J, Kaiser UB, Slaugenhaupt SA, Gusella JF, O'Rahilly S, Carlton MB, Crowley WF,Jr, Aparicio SA, Colledge WH. The GPR54 gene as a regulator of puberty. N Engl J Med 2003; 17: 1614-1627.

5. de Roux N, Genin E, Carel JC, Matsuda F, Chaussain JL, Milgrom E. Hypogonadotropic hypogonadism due to loss of function of the KiSS1-derived peptide receptor GPR54. Proc Natl Acad Sci U S A 2003; 19: 10972-10976.

6. Franceschini I, Lomet D, Cateau M, Delsol G, Tillet Y, Caraty A. Kisspeptin immunoreactive cells of the ovine preoptic area and arcuate nucleus co-express estrogen receptor alpha. Neurosci Lett 2006; 3: 225-230.

7. Nestor CC, Briscoe AM, Davis SM, Valent M, Goodman RL, Hileman SM. Evidence of a role for kisspeptin and neurokinin B in puberty of female sheep. Endocrinology 2012; 6: 2756-2765.

8. Topaloglu AK, Reimann F, Guclu M, Yalin AS, Kotan LD, Porter KM, Serin A, Mungan NO, Cook JR, Ozbek MN, Imamoglu S, Akalin NS, Yuksel B, O'Rahilly S, Semple RK. TAC3 and 
TACR3 mutations in familial hypogonadotropic hypogonadism reveal a key role for Neurokinin B in the central control of reproduction. Nat Genet 2009; 3: 354-358.

9. Porter KL, Hileman SM, Hardy SL, Nestor CC, Lehman MN, Goodman RL. Neurokinin-3 receptor activation in the retrochiasmatic area is essential for the full pre-ovulatory luteinising hormone surge in ewes. J Neuroendocrinol 2014; 11: 776-784.

10. Billings HJ, Connors JM, Altman SN, Hileman SM, Holaskova I, Lehman MN, McManus CJ, Nestor CC, Jacobs BH, Goodman RL. Neurokinin B acts via the neurokinin-3 receptor in the retrochiasmatic area to stimulate luteinizing hormone secretion in sheep. Endocrinology 2010; 8: 3836-3846.

11. Grachev P, Porter KL, Coolen LM, McCosh RB, Connors JM, Hileman SM, Lehman MN, Goodman RL. Surge-Like Luteinising Hormone Secretion Induced by Retrochiasmatic Area NK3R Activation is Mediated Primarily by Arcuate Kisspeptin Neurones in the Ewe. J Neuroendocrinol 2016; 6: 10.1111/jne.12393.

12. Goodman RL, Hileman SM, Nestor CC, Porter KL, Connors JM, Hardy SL, Millar RP, Cernea M, Coolen LM, Lehman MN. Kisspeptin, neurokinin B, and dynorphin act in the arcuate nucleus to control activity of the GnRH pulse generator in ewes. Endocrinology 2013; 11: 42594269.

13. Gallo RV. Kappa-opioid receptor involvement in the regulation of pulsatile luteinizing hormone release during early pregnancy in the rat. J Neuroendocrinol 1990; 5: 685-691. 
14. Foradori CD, Goodman RL, Adams VL, Valent M, Lehman MN. Progesterone increases dynorphin a concentrations in cerebrospinal fluid and preprodynorphin messenger ribonucleic Acid levels in a subset of dynorphin neurons in the sheep. Endocrinology 2005; 4: 1835-1842.

15. Weems PW, Witty CF, Amstalden M, Coolen LM, Goodman RL, Lehman MN. kappaOpioid Receptor Is Colocalized in GnRH and KNDy Cells in the Female Ovine and Rat Brain. Endocrinology 2016; 6: 2367-2379.

16. Lopez JA, Bedenbaugh MN, McCosh RB, Weems PW, Meadows LJ, Wisman B, Coolen LM, Goodman RL, Hileman SM. Does Dynorphin Play a Role in the Onset of Puberty in Female Sheep?. J Neuroendocrinol 2016; 12: 10.1111/jne.12445.

17. Anderson GM, Connors JM, Hardy SL, Valent M, Goodman RL. Oestradiol microimplants in the ventromedial preoptic area inhibit secretion of luteinizing hormone via dopamine neurones in anoestrous ewes. J Neuroendocrinol 2001; 12: 1051-1058.

18. Foradori CD, Coolen LM, Fitzgerald ME, Skinner DC, Goodman RL, Lehman MN. Colocalization of progesterone receptors in parvicellular dynorphin neurons of the ovine preoptic area and hypothalamus. Endocrinology 2002; 11: 4366-4374.

19. Whisnant CS, Goodman RL. Effects of an opioid antagonist on pulsatile luteinizing hormone secretion in the ewe vary with changes in steroid negative feedback. Biol Reprod 1988; 5: 10321038. 
20. Mahachoklertwattana P, Black SM, Kaplan SL, Bristow JD, Grumbach MM. Nitric oxide synthesized by gonadotropin-releasing hormone neurons is a mediator of N-methyl-D-aspartate (NMDA)-induced GnRH secretion. Endocrinology 1994; 4: 1709-1712.

21. Navarro VM, Ruiz-Pino F, Sanchez-Garrido MA, Garcia-Galiano D, Hobbs SJ, ManfrediLozano M, Leon S, Sangiao-Alvarellos S, Castellano JM, Clifton DK, Pinilla L, Steiner RA, Tena-Sempere M. Role of neurokinin B in the control of female puberty and its modulation by metabolic status. J Neurosci 2012; 7: 2388-2397.

22. Ramaswamy S, Seminara SB, Ali B, Ciofi P, Amin NA, Plant TM. Neurokinin B stimulates GnRH release in the male monkey (Macaca mulatta) and is colocalized with kisspeptin in the arcuate nucleus. Endocrinology 2010; 9: 4494-4503.

23. Amstalden M, Coolen LM, Hemmerle AM, Billings HJ, Connors JM, Goodman RL, Lehman MN. Neurokinin 3 receptor immunoreactivity in the septal region, preoptic area and hypothalamus of the female sheep: colocalisation in neurokinin B cells of the arcuate nucleus but not in gonadotrophin-releasing hormone neurones. J Neuroendocrinol 2010; 1: 1-12.

24. Takase K, Uenoyama Y, Inoue N, Matsui H, Yamada S, Shimizu M, Homma T, Tomikawa J, Kanda S, Matsumoto H, Oka Y, Tsukamura H, Maeda KI. Possible role of oestrogen in pubertal increase of Kiss1/kisspeptin expression in discrete hypothalamic areas of female rats. $\mathrm{J}$ Neuroendocrinol 2009; 6: 527-537.

25. Gill JC, Wang O, Kakar S, Martinelli E, Carroll RS, Kaiser UB. Reproductive hormonedependent and -independent contributions to developmental changes in kisspeptin in GnRHdeficient hypogonadal mice. PLoS One 2010; 7: e11911. 
26. Han SK, Gottsch ML, Lee KJ, Popa SM, Smith JT, Jakawich SK, Clifton DK, Steiner RA, Herbison AE. Activation of gonadotropin-releasing hormone neurons by kisspeptin as a neuroendocrine switch for the onset of puberty. J Neurosci 2005; 49: 11349-11356.

27. Redmond JS, Baez-Sandoval GM, Spell KM, Spencer TE, Lents CA, Williams GL, Amstalden M. Developmental changes in hypothalamic Kiss1 expression during activation of the pulsatile release of luteinising hormone in maturing ewe lambs. J Neuroendocrinol 2011; 9: 815822.

28. Burke MC, Letts PA, Krajewski SJ, Rance NE. Coexpression of dynorphin and neurokinin B immunoreactivity in the rat hypothalamus: Morphologic evidence of interrelated function within the arcuate nucleus. J Comp Neurol 2006; 5: 712-726.

29. Navarro VM, Gottsch ML, Chavkin C, Okamura H, Clifton DK, Steiner RA. Regulation of gonadotropin-releasing hormone secretion by kisspeptin/dynorphin/neurokinin B neurons in the arcuate nucleus of the mouse. J Neurosci 2009; 38: 11859-11866.

30. Rance NE, Dacks PA, Mittelman-Smith MA, Romanovsky AA, Krajewski-Hall SJ. Modulation of body temperature and LH secretion by hypothalamic KNDy (kisspeptin, neurokinin B and dynorphin) neurons: a novel hypothesis on the mechanism of hot flushes. Front Neuroendocrinol 2013; 3: 211-227.

31. Rezai-Zadeh K, Munzberg H. Integration of sensory information via central thermoregulatory leptin targets. Physiol Behav 2013; : 49-55. 
32. Webber ES, Bonci A, Krashes MJ. The elegance of energy balance: Insight from circuit-level manipulations. Synapse 2015; 9: 461-474.

33. Mansour A, Fox CA, Burke S, Meng F, Thompson RC, Akil H, Watson SJ. Mu, delta, and kappa opioid receptor mRNA expression in the rat CNS: an in situ hybridization study. J Comp Neurol 1994; 3: 412-438.

34. DePaoli AM, Hurley KM, Yasada K, Reisine T, Bell G. Distribution of kappa opioid receptor mRNA in adult mouse brain: an in situ hybridization histochemistry study. Mol Cell Neurosci 1994; 4: 327-335.

35. Peckys D, Landwehrmeyer GB. Expression of mu, kappa, and delta opioid receptor messenger RNA in the human CNS: a 33P in situ hybridization study. Neuroscience 1999; 4: 1093-1135.

\section{FIGURE LEGENDS}

Figure 1. Effect of senktide- or nor-BNI-containing microimplants placed in the ARC on LH secretion in prepubertal ewes. Placement of microimplants containing either senktide (black circles) or nor-BNI (gray circles) within the ARC. Placement of empty microimplants are not shown to allow for better visualization of microimplants containing either senktide or nor-BNI (A). Mean \pm SEM LH concentrations (left), LH pulse frequency (middle) or LH pulse amplitude (right) in prepubertal ewes that received blank, senktide- or nor-BNI-containing microimplants (B). Representative LH secretory profiles of prepubertal ewes that received blank (left), 
senktide-containing (middle) or nor-BNI-containing (right) microimplants (C). Asterisk indicates significant differences $(\mathrm{P}<0.05)$. $\mathrm{fx}$, fornix; $\mathrm{mt}$, mammillothalamic tract.

Figure 2. Effect of senktide- or nor-BNI-containing microimplants placed in the POA on LH secretion in prepubertal ewes. Placement of microimplants within the POA for each animal (A). Mean \pm SEM LH concentrations (left), LH pulse frequency (middle) or LH pulse amplitude (right) in prepubertal ewes that received blank, senktide- or nor-BNI-containing microimplants (B). Representative LH secretory profiles of two prepubertal ewes that received blank, senktideor nor-BNI-containing microimplants (C). Asterisk indicates significant differences $(\mathrm{P}<0.05)$. ac, anterior commissure; fx, fornix; LS, lateral septum; mPOA, medial preoptic area; oc, optic chiasm; OVLT, organum vasculosum of the lamina terminalis.

Figure 3. NK3R-IR cells are present in the POA and ARC of ewes. Low magnification image of NK3R-IR cells and fibers in the POA of an OVX prepubertal ewe (A). Adult OVX ewes in the non-breeding season had an increased number of NK3R-IR cells in the POA compared to OVX and OVX+E prepubertal ewes (B). Prepubertal OVX and OVX+E ewes had an increased number of NK3R-IR cells in the ARC compared to Adult OVX ewes in the non-breeding season (C). Scale bar in $A=200 \mu \mathrm{m}$. Asterisks indicate significant differences $(\mathrm{P}<0.05)$.

Figure 4. NK3R associations onto NKB and non-NKB cells in the arcuate nucleus of ewes. Representative images showing NKB (upper left), NK3R (upper right), Nissl (lower left), and a merged image (lower right). Arrows in the merged image indicate cells exhibiting many NK3R associations. Arrowheads indicate cells exhibiting little to no NK3R associations (A). An 
increased percentage of NKB cells exhibited NK3R associations compared to non-NKB cells in the ARC of prepubertal OVX and OVX+E ewes (B). The average number of NK3R associations was greater on NKB cells compared to non-NKB cells in the ARC of prepubertal OVX and $\mathrm{OVX}+\mathrm{E}$ ewes. The average number of associations onto non-NKB cells in adult ewes was greater than in prepubertal ewes (Differing letters indicate significant differences between age groups $(\mathrm{P}<0.05))(\mathrm{C})$. Scale bar in $\mathrm{A}=50 \mathrm{um}$. Asterisks indicate significant differences between cell types $(\mathrm{P}<0.05)$.

Figure 5. Representative images demonstrating GnRH colocalization with KOR. Two neurons shown to be expressing GnRH (left), KOR (middle) and a merged image (right) in the POA of a prepubertal ewe. Arrows in the middle panel indicate KOR neurons that also contain GnRH. Arrowheads indicate KOR neurons that do not contain GnRH. Scale bar $=50 \mu \mathrm{m}$. 
Figure 1

A
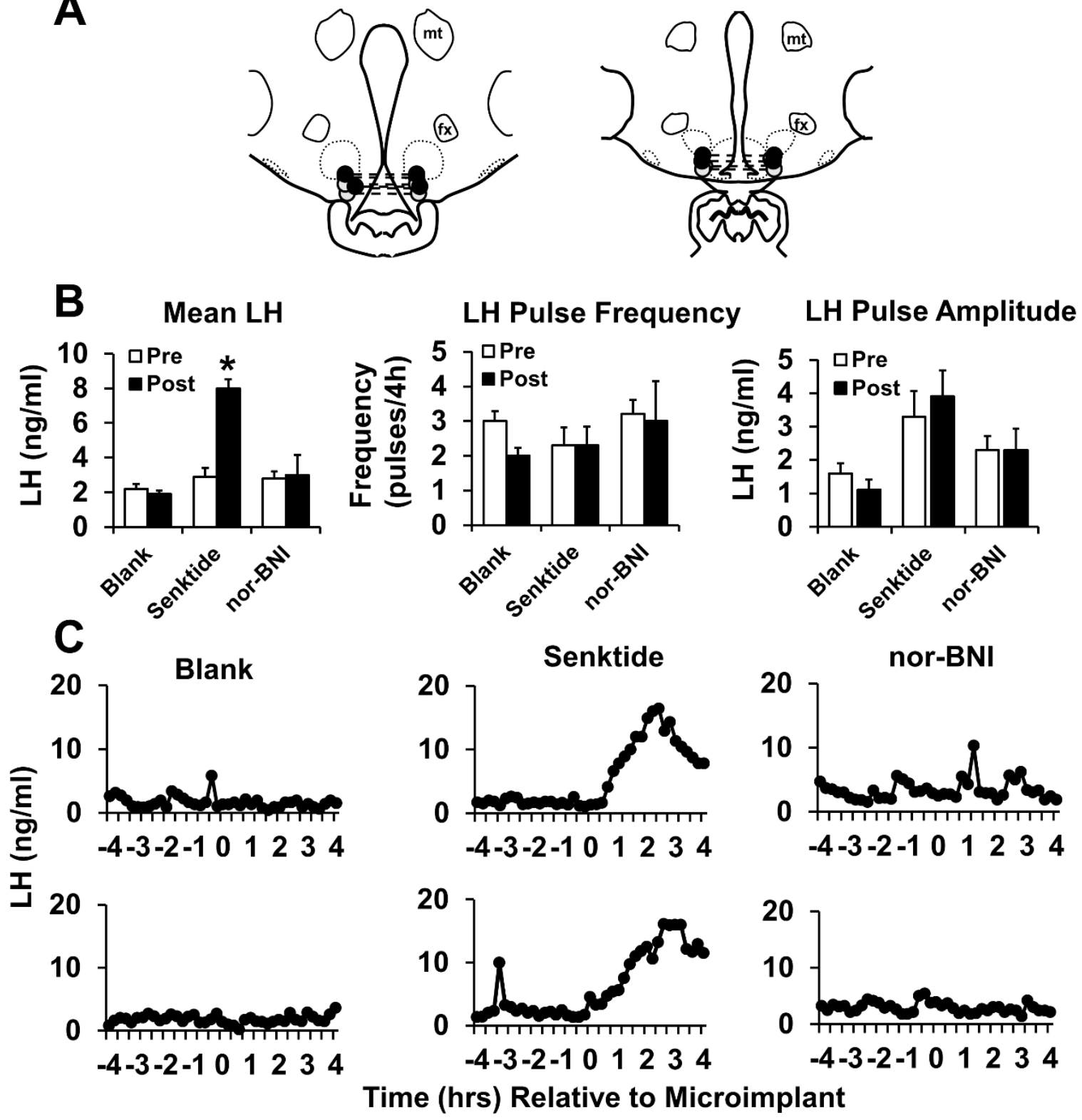
Figure 2

A
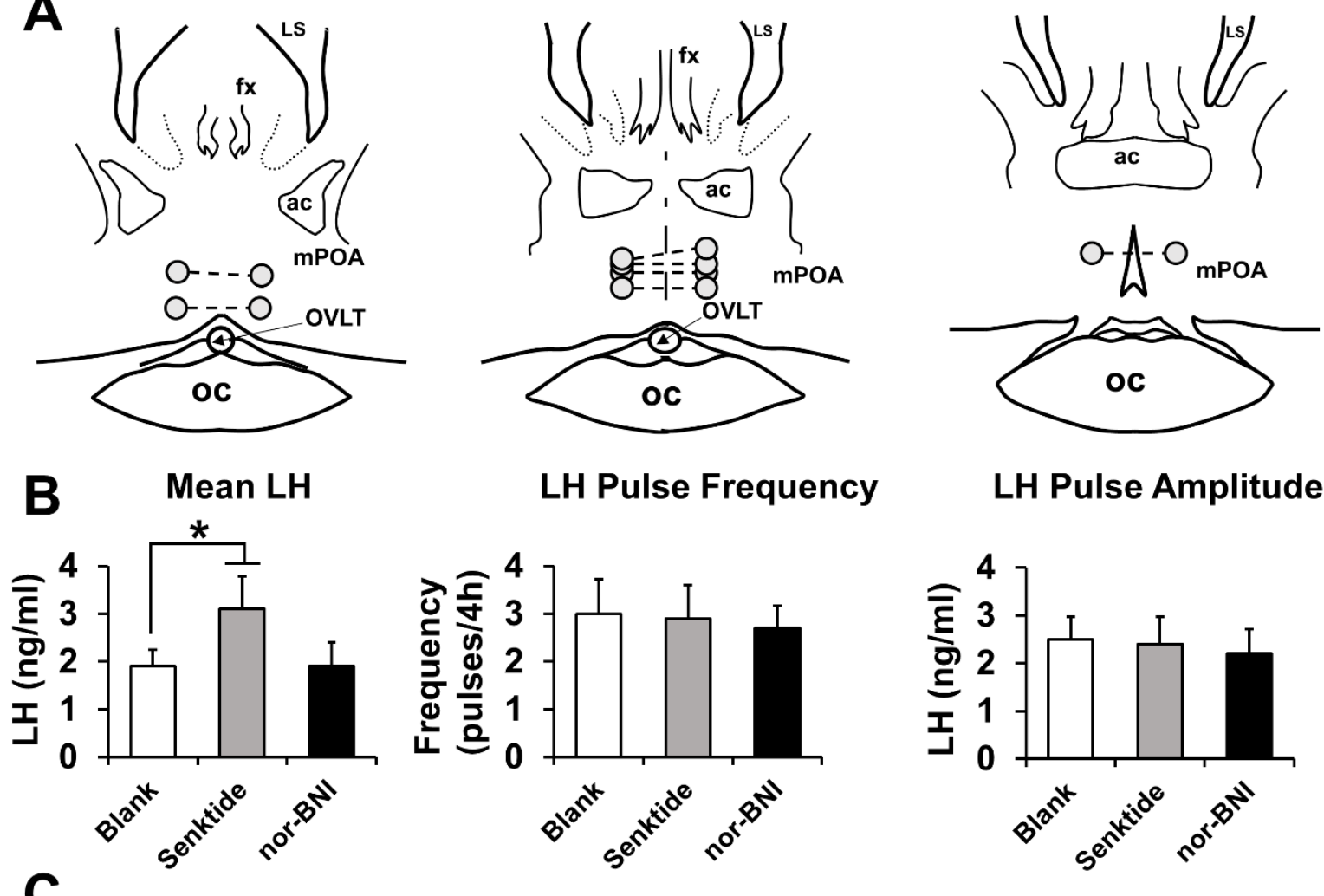

LH Pulse Frequency

LH Pulse Amplitude
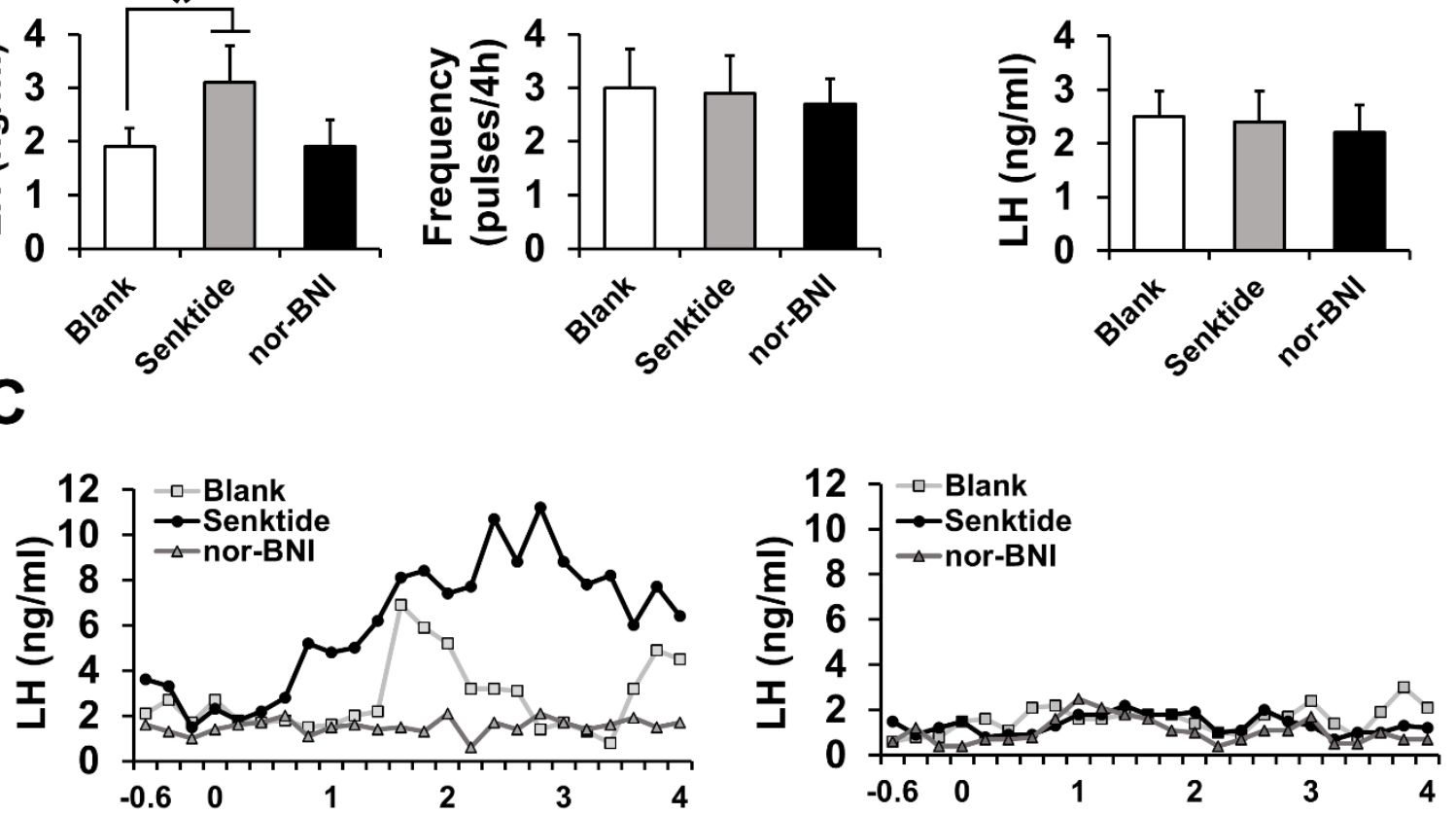

Time (hrs) Relative to Microimplant Time (hrs) Relative to Microimplant 
Figure 3
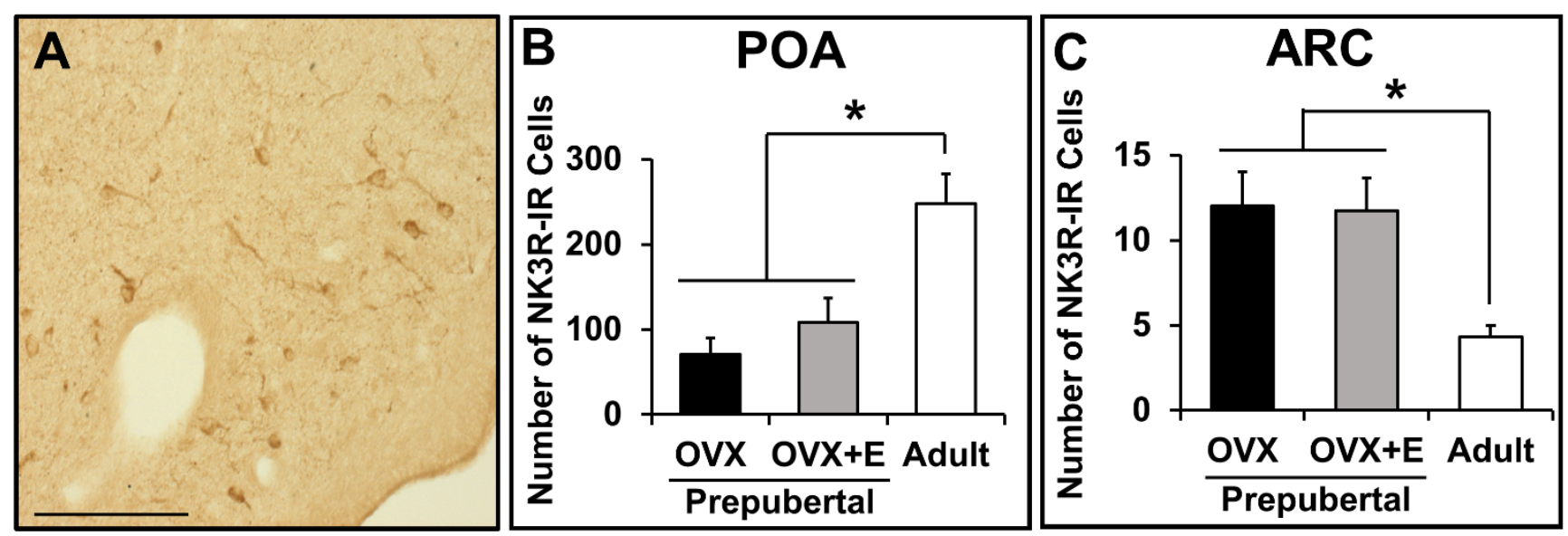
Figure 4

A

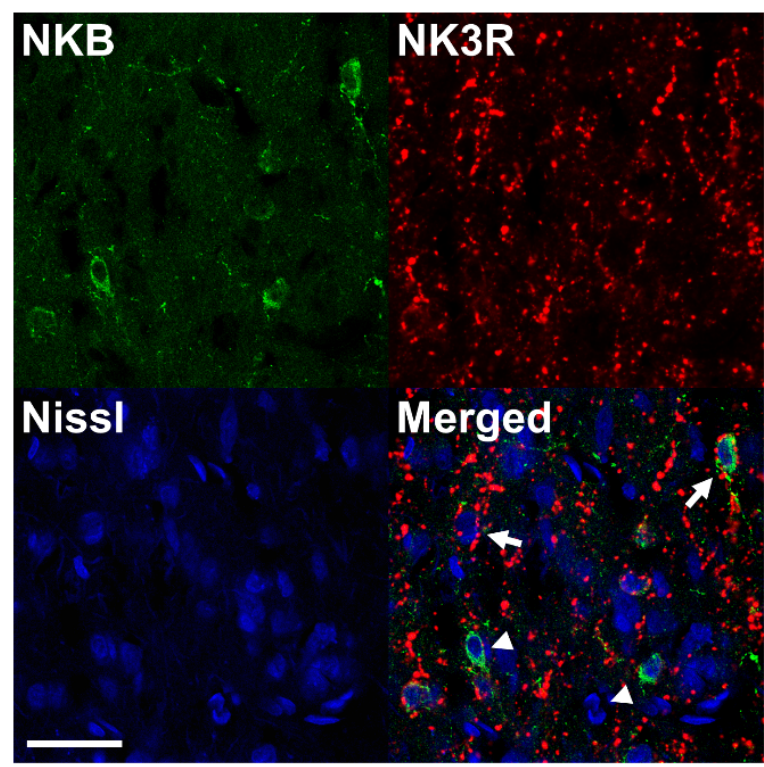

B
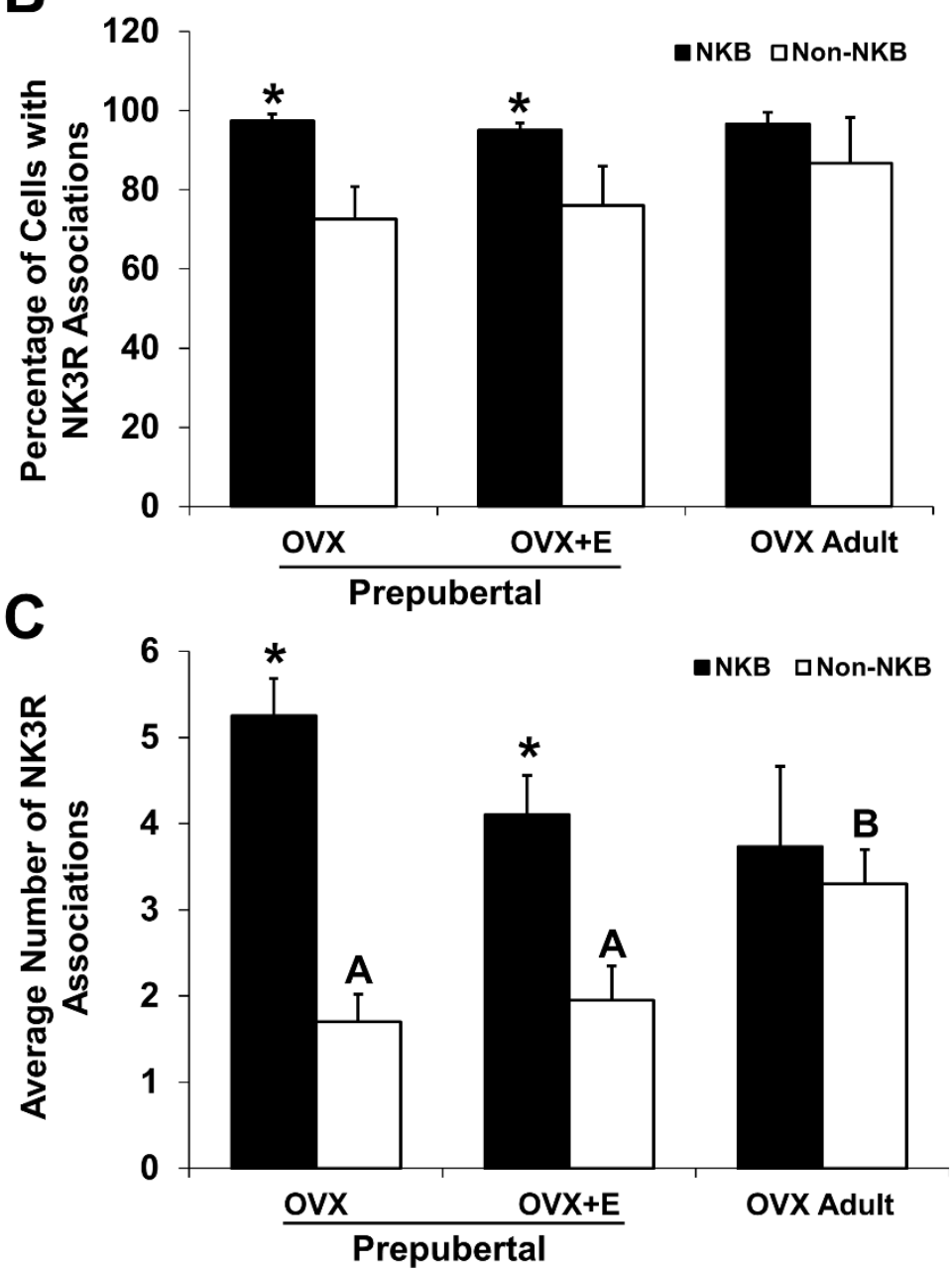
Figure 5






\title{
CHAPTER 3
}

\section{KISSPEPTIN, GnRH, AND ER $\alpha$ COLOCALISE WITH nNOS NEURONES IN PREPUBERTAL FEMALE SHEEP}

\author{
Michelle N. Bedenbaugh ${ }^{1}$, Ryan C. O’Connell ${ }^{2}$, Justin A. Lopez ${ }^{1}$, Richard B. McCosh ${ }^{1}$, Robert \\ L. Goodman ${ }^{1}$, Stanley M. Hileman ${ }^{1}$ \\ Department of Physiology and Pharmacology, West Virginia University, Morgantown, WV1; \\ Davis and Elkins College, Elkins, WV²;
}

Abbreviated Title: nNOS neurones in prepubertal sheep

Key Terms: sheep, puberty, nitric oxide, kisspeptin, GnRH

This research was originally published in the Journal of Neuroendocrinology.

Bedenbaugh MN, O’Connell RC, Lopez JA, McCosh RB, Goodman RL, Hileman SM. Kisspeptin, GnRH, and ER $\alpha$ colocalise with nNOS neurones in prepubertal female sheep. Journal of Neuroendocrinology. 2018 January;30(1). doi: 10.1111/jne.12560. 


\section{ABSTRACT}

Puberty is a process which integrates multiple inputs that ultimately cause an increase in gonadotrophin-releasing hormone $(\mathrm{GnRH})$ secretion. While kisspeptin neurones play an integral role in GnRH secretion and puberty onset, other systems are also likely important. One potential component is nitric oxide (NO), a gaseous neurotransmitter synthesized by nitric oxide synthase (NOS). In this study, we sought to neuroanatomically characterise neuronal NOS (nNOS) in prepubertal female sheep and determine if oestradiol would exert effects on this system. Luteinising hormone secretion was reduced by oestradiol treatment in prepubertal ovariectomised ewes. Neurones immunoreactive for nNOS were identified in several areas with the greatest number present in the ventrolateral portion of the ventromedial hypothalamus followed by the ventromedial hypothalamus, preoptic area (POA) and arcuate nucleus (ARC). Next, we determined if nNOS neurones contained oestrogen receptor $\alpha(E R \alpha)$ and could potentially communicate oestradiol $\left(\mathrm{E}_{2}\right)$ feedback to GnRH neurones. Neuronal nitric oxide synthase neurones contained ER $\alpha$ with the percentage of coexpression (12 to 40\%) depending upon the area analyzed. We next investigated if a neuroanatomical relationship existed between nNOS and kisspeptin or nNOS and GnRH neurones. A high percentage of kisspeptin neurones in the POA (79\%) and ARC (99\%) colocalised with nNOS. Kisspeptin close-contacts were also associated with nNOS neurones. A greater number of close-contacts were observed in the ARC than the POA. A high percentage of POA GnRH neurones (79\%) also expressed nNOS, but no GnRH close-contacts were observed onto nNOS neurones. Neither the numbers of nNOS neurones in the POA or hypothalamus nor the percentage of nNOS coexpression with GnRH, kisspeptin or ER $\alpha$ were influenced by oestradiol. These experiments reveal that a neuroanatomical relationship exists between both nNOS and kisspeptin and nNOS and GnRH in 
prepubertal ewes. Therefore, nNOS may act both directly and indirectly to influence GnRH secretion in prepubertal sheep.

\section{INTRODUCTION}

Puberty is a complex process that has been investigated extensively in female mammals. In prepubertal female sheep, low concentrations of oestradiol $\left(E_{2}\right)$ potently inhibit the release of gonadotrophin-releasing hormone ( $\mathrm{GnRH})$ and thus luteinising hormone (LH). As female sheep

approach puberty, the ability of $\mathrm{E}_{2}$ to inhibit GnRH and LH secretion decreases thus allowing for an increase in the frequency of GnRH and LH release (1). While it is evident that $E_{2}$ plays a critical role in the inhibition of GnRH and LH secretion prior to the initiation of puberty, the neural mechanisms by which this feedback is communicated to GnRH neurones is not well established. Oestradiol negative feedback cannot be directly communicated to GnRH neurones because these neurones do not express oestrogen receptor alpha (ER $\alpha)$, the oestrogen receptor known to mediate oestrogenic regulation of GnRH secretion $(2,3)$. Therefore, in sheep, as well as in several other mammalian species, intermediary neurones that do express ER $\alpha$ must exist to transmit these effects to GnRH neurones.

In sheep, rodents, and primates, kisspeptin appears to play a critical role in puberty onset. The importance of kisspeptin in the initiation of puberty was first discovered when mutations in either kisspeptin or its receptor, KISS1R, led to an absence of puberty and ultimately resulted in infertility in humans (4-6). Kisspeptin neurones are present in both the preoptic area (POA) and arcuate nucleus (ARC) of the hypothalamus, contain $\mathrm{ER} \alpha$ (7), and potently stimulate $\mathrm{GnRH} / \mathrm{LH}$ secretion $(8,9)$. However, kisspeptin is unlikely to be the sole communicator involved in puberty onset $(10,11)$. 
Nitric oxide (NO) is another potential intermediary that may influence the initiation of puberty. Neuronal nitric oxide synthase (nNOS) is one of three forms of an enzyme that oxidizes L-arginine to L-citrulline and NO (12). In mice and rats, a high percentage of nNOS neurones contain ER $\alpha$ (13-16). Nitric oxide stimulates GnRH and LH release in rats (17), and deletion of nNOS results in hypogonadism and infertility in mice (18). Recent evidence also suggests NO release may be influenced directly by kisspeptin. Kisspeptin close-contacts have been observed onto nNOS neurones in the POA and ARC of adult female mice, but only nNOS neurones in the POA express KISS1R (19).

Very few studies have examined the role of NO in the control of GnRH and LH secretion in species other than rodents, and none have characterised the expression of nNOS in prepubertal sheep. Therefore, we aimed to evaluate the distribution of nNOS neurones in the POA and hypothalamus of prepubertal sheep, determine if nNOS neurones express ER $\alpha$, and examine if a neuroanatomical relationship exists between nNOS and kisspeptin or nNOS and GnRH neurones. We also investigated whether the presence or absence of $E_{2}$ would affect these relationships.

\section{MATERIALS AND METHODS}

\section{$\underline{\text { Animals }}$}

All experiments were conducted at the West Virginia University Food Animal Research Facility in Morgantown, West Virginia. Procedures were approved by the West Virginia Animal Care and Use Committee and were performed in accordance with National Institutes of Health guidelines for use of animals in research. Twelve Suffolk ewe lambs born in late February to early March were purchased from a local producer and housed indoors where they received a commercial premium alfalfa-timothy cube food ration (crude protein $\geq 12 \%$, crude fat $\geq 18 \%$, 
crude fibre $\leq 32 \%$; Triple Crown Nutrition, Inc., Wayzata, MN, USA) and had free access to water and a mineral block supplement. Experiments were performed in the fall (August) when lambs were 5-6 months of age and still prepubertal. Lambs were housed two per pen (2.06 x 2.06 metres) on raised flooring with a clear view of all other sheep. Indoor lighting simulated the natural changes in day length characteristic of the fall season. Ovariectomies (OVX) were performed under aseptic conditions. Animals were anesthetised by i.v. injection of ketamine (7 $\mathrm{mg} / \mathrm{kg})$ and midazolam $(0.3 \mathrm{mg} / \mathrm{kg})$ and then maintained on $2 \%$ isoflurane. Ovarian vasculature was ligated and ovaries removed via a midventral incision. Ewe lambs were selected randomly to receive either no implant (OVX; $\mathrm{n}=6)$ or a subcutaneous 1-cm long Silastic (inner diameter 0.34cm, outer diameter 0.46cm; Dow Corning Corp., Midland, MI, USA) implant containing crystalline oestradiol (Sigma-Aldrich, St. Louis, MO, USA) (OVX+E; n=6). Two weeks after OVX, blood samples were collected every 12 min for $4 \mathrm{~h}$ by jugular venipuncture, placed in heparinized tubes and plasma was stored at $-20^{\circ} \mathrm{C}$ until assayed for $\mathrm{LH}$. Immediately following the final blood sample, hypothalami were collected as described previously (20). Briefly, all sheep were heparinised (20,000 U) and euthanised using an intravenous overdose of sodium pentobarbital (Euthasol; Webster Veterinary, Devens, MA, USA). Heads were removed and perfused via carotid arteries with $4 \mathrm{~L}$ of $4 \%$ paraformaldehyde in $0.1 \mathrm{M}$ phosphate buffer (PB;

$\mathrm{pH}$ 7.4) containing $0.1 \%$ sodium nitrite. Blocks of tissue containing the POA and hypothalamus were removed and stored in a $4 \%$ paraformaldehyde solution for $24 \mathrm{~h}$ at $4^{\circ} \mathrm{C}$ and transferred to 20\% sucrose until sectioned. Frozen coronal sections $(30 \mu \mathrm{m})$ were cut with a freezing microtome, collected in 5 series (150 $\mu \mathrm{m}$ apart) and stored in cryopreservative until the time of immunohistochemical staining.

\section{Single-label immunohistochemistry for nNOS characterization}


To initially characterise the distribution of nNOS neurones in the hypothalamus of prepubertal ewes, every fourth hemisection from one complete series of sections (600 $\mu \mathrm{m})$ throughout the POA and hypothalamus was used from one OVX and one OVX+E ewe. On day 1 of the protocol, sections were washed $4 \times 5$ min in $0.1 \mathrm{M}$ phosphate-buffered saline (PBS) to remove excess cryoprotectant and stored overnight at $4^{\circ} \mathrm{C}$. The next day, sections were washed 4x5 min in PBS, placed in $1 \% \mathrm{H}_{2} \mathrm{O}_{2}$ for 10 min, and subsequently washed $4 \times 5$ min in PBS. Tissue was then incubated for at least $1 \mathrm{~h}$ in a blocking solution containing PBS, $0.4 \%$ Triton X100 (PBSTX; Sigma-Aldrich, St. Louis, MO, USA) and 4\% normal goat serum (NGS; Jackson ImmunoResearch Laboratories, Inc., West Grove, PA, USA) in PBS. Sections were incubated in a solution containing rabbit anti-nNOS antiserum (Cat.\#24287; 1:15,000; ImmunoStar antibody, Hudson, WI, USA) in PBSTX and 4\% NGS at room temperature for $16 \mathrm{~h}$. After incubation with the primary antibody, sections were washed and then incubated in a solution containing biotinylated goat anti-rabbit IgG (1:400; Vector Laboratories, Burlingame, CA, USA), PBSTX, and 4\% NGS for $1 \mathrm{~h}$. The sections were washed and incubated in a solution containing avidinbiotin horseradish-peroxidase conjugate (Vectastain Elite ABC, 1:600; Vector Laboratories) for $1 \mathrm{~h}$. Sections were then washed and incubated in a solution containing 3,3-diaminobenzidine (DAB; $0.2 \mathrm{mg} / \mathrm{ml}$; Sigma-Aldrich) and hydrogen peroxide (0.012\%; Sigma-Aldrich) in PBS for 10 min. The sections were washed, mounted on Superfrost microscope slides (Fisher Scientific, Pittsburgh, PA, USA), and coverslipped using Eukitt Mounting Reagent (Fisher Scientific).

\section{Dual-label immunohistochemistry for nNOS and ER}

To examine the relationship between $\mathrm{nNOS}$ and $\mathrm{ER} \alpha, 4$ hemisections containing the POA (with 2 being at the level of the organum vasculosum lamina terminalis (OVLT) and 2 in the medial POA (mPOA)), 3 sections containing the ventromedial hypothalamus (VMH), 4 sections 
containing the ventrolateral portion of the ventromedial hypothalamus (VL-VMH) and 2 sections in each the rostral, middle, and caudal arcuate from $6 \mathrm{OVX}$ and $6 \mathrm{OVX}+\mathrm{E}$ ewes were selected for analysis. The protocol described above was replicated with the following changes: mouse anti-ER $\alpha$ antiserum (Cat.\#M7047; Clone 1D5, 1:500; DAKO Corp.) was the first primary antibody used, biotinylated goat anti-mouse IgG (1:400; Vector Laboratories) was the secondary antibody, and nickel-sulfate (2\%; Sigma-Aldrich) was added to DAB to produce a blue-black nuclear reaction product. The sections were washed and incubated in PBS containing 1\% hydrogen peroxide for 10 min. After further washing, the sections were incubated in PBSTX and $4 \%$ NGS for at least $1 \mathrm{~h}$. The sections were then incubated in a solution containing rabbit anti-nNOS antiserum $(1: 15,000)$ in PBSTX, and 4\% NGS for $16 \mathrm{~h}$. After incubation with the primary antibody, the sections were washed and then incubated in a solution containing biotinylated goat anti-rabbit IgG (1:400; Vector Laboratories), PBSTX, and 4\% NGS for $1 \mathrm{~h}$. The sections were washed and incubated in a solution containing avidin-biotin horseradishperoxidase conjugate (Vectastain Elite ABC, Vector Laboratories; 1:600) for $1 \mathrm{~h}$. Sections were then washed and incubated in a solution containing 3,3-diaminobenzidine (DAB; $0.2 \mathrm{mg} / \mathrm{ml}$ ) with hydrogen peroxide (0.012\%; Sigma) in PBS for 10 min which results in a brown cytoplasmic reaction product. The sections were washed, mounted on Superfrost microscope slides (Fisher Scientific,), and coverslipped using Eukitt Mounting Reagent (Fisher Scientific).

\section{Dual-label immunofluorescent detection of nNOS and kisspeptin}

In order to determine if an anatomical relationship existed between nNOS and kisspeptin, 4 hemisections containing the POA ( 2 at the level of the OVLT, 2 in the mPOA) and 4 sections containing the middle to caudal ARC were selected from 6 OVX and 6 OVX+E prepubertal ewes. The same steps as described above for the previous two experiments were used until 
tissue was placed in a blocking solution containing 20\% NGS instead of 4\% NGS. Tissue sections were placed in a solution containing rabbit anti-kisspeptin antiserum (Cat.\#AB-9754; 1:10,000; Millipore, Darmstadt, Germany) in PBSTX and 4\% NGS for 16 h. After incubation with the primary antibody, sections were incubated in a solution containing biotinylated goat anti-rabbit IgG and a solution containing avidin-biotin horseradish-peroxidase conjugate as stated in the protocols above. Sections were then washed and incubated for $10 \mathrm{~min}$ in biotinylated tyramine (TSA; 1:250; Perkin Elmer, Waltham, MA, USA) in PBS containing 3\% $\mathrm{H}_{2} \mathrm{O}_{2}$ per $1 \mathrm{~mL}$ of solution. After washing, sections were incubated in a solution containing DyLight green 488-streptavidin (1:200, Fisher Scientific) for $1 \mathrm{~h}$ followed by washes and incubation in PBSTX and 4\% NGS for at least $1 \mathrm{~h}$. Sections were incubated in rabbit anti-nNOS antiserum $(1: 1,000)$ in PBSTX, and 4\% NGS for $16 \mathrm{~h}$. The following day, sections were incubated in Alexa555 goat anti-rabbit (1:200; Life Technologies, Carlsbad, CA, USA) for 1 h, washed, mounted on Superfrost slides (Fisher Scientific), coverslipped using Gelvatol and stored in the dark at $4^{\circ} \mathrm{C}$ until analysis.

\section{Dual-label immunofluorescent detection of nNOS and GnRH}

To detect nNOS and GnRH neurones in prepubertal ewes, the same protocol as above was used with minor changes. The rabbit anti-nNOS antiserum (Immunostar) was the TSA-amplified primary antibody and was therefore used at a concentration of 1:10,000. Rabbit anti-GnRH antiserum (Cat.\#20075, Immunostar) was used at a concentration of 1:200. This protocol was used to stain 4 POA sections ( 2 at the level of the OVLT) each from 6 OVX and 6 OVX+E prepubertal ewes.

\section{Immunohistochemistry Controls}


Specificity of the nNOS antibody in sheep tissue was tested using recommended controls for immunostaining including peptide blocking controls and primary antibody omission controls (21). These controls abolished all nNOS staining (Supplemental Figure 1). In addition to testing the specificity of the nNOS antibody, we also ensured there was no cross-reactivity between any of the antibodies used in dual-label staining protocols. In these situations, controls in which antibodies were preadsorbed with the opposite peptide or one of the primary antibodies was omitted from the protocol were used (Supplemental Figures 2 and 3).

\section{$\underline{\text { Data Analysis }}$}

Immunohistochemistry

The distribution of nNOS neurones in all tissue sections from 1 OVX and 1 OVX+E ewe was visualised and mapped using an AZ70 transmitted light microscope (Olympus, Center Valley, PA, USA).

The total number of nNOS neurones, as well as the number and percentage of nNOS neurones that contained ER $\alpha$, was determined using an AZ70 transmitted light microscope (Olympus). For all experiments, cell counts were made by a single observer blinded to treatment groups.

The number of kisspeptin close-contacts onto nNOS neurones in prepubertal ewes was determined by capturing images of 10 nNOS neurones in the POA and 10 nNOS neurones in the ARC of each animal using a LSM 510 laser scanning confocal system (Zeiss, Thornwood, NY, USA) on a Zeiss Axio Image Z1 upright microscope with a Plan Apochromat x 63/1.4 oil objective. Confocal z-stacks of optical sections were taken at $1 \mu \mathrm{m}$ intervals through each nNOS neurone. The number of close-contacts onto nNOS cell bodies was analysed using ZEN software (Zeiss). Because contacts were counted through the entire z-stack, markers were placed on each individual contact to ensure that no contacts were counted more than once. Orthogonal 
views were used to confirm that contacts were touching the cell in all planes. The same approach was used to identify the number of GnRH close-contacts onto nNOS neurones in the POA of prepubertal ewes.

To delineate the percentage of kisspeptin and nNOS neurones and GnRH and nNOS neurones that were colocalised in prepubertal ewes, sections were visualised using a fluorescent microscope (VS120, Olympus). For kisspeptin and nNOS analyses, the number of kisspeptin neurones, the number of nNOS neurones, and the percentage of each neuronal population that were colocalised with each other was recorded in 2 mPOA sections and 2 middle to caudal ARC sections for each animal. For GnRH and nNOS analyses, the number of GnRH neurones, the number of nNOS neurones, and the percentage of each neuronal population that were colocalised with each other was determined in the POA only.

Assays

Luteinising hormone concentrations were measured in duplicate by radioimmunoassay as described previously (22) using reagents provided by the National Hormone and Peptide Program (Torrance, CA, USA). Assays used 100 to $200 \mu \mathrm{L}$ of plasma and sensitivity averaged $0.07 \mathrm{ng} /$ tube (NIHS24) with intra- and interassay coefficients of variations being $12.7 \%$ and $18.2 \%$ respectively.

\section{Statistical Analysis}

Similar to previous work, three criteria were used to determine an LH pulse; (1) a peak must occur within two samples of the previous nadir; (2) the amplitude must be greater than the sensitivity of the LH assay; and (3) the LH concentration at the peak must exceed the 95\% confidence limits (based on overall assay variability) of the concentration at both the preceding and subsequent nadir (23). Mean LH, LH pulse amplitude, and mean nNOS cell numbers were 
compared by t-test. The percentage of nNOS cells that contained ER $\alpha$ and the percent colocalisation between nNOS and kisspeptin and nNOS and GnRH cells were analysed via chisquared analysis. A Wilcoxon Mann-Whitney test was used to compare LH pulse frequency. The number of kisspeptin and GnRH close-contacts were transformed to normalize variance using the square root and compared by t-test. $\mathrm{P}<0.05$ was considered statistically significant.

\section{RESULTS}

Circulating mean concentrations of LH were greater $(\mathrm{P}<0.0001)$ in OVX $(6.3 \pm 0.9 \mathrm{ng} / \mathrm{ml})$ than in $\mathrm{OVX}+\mathrm{E}$ ewes $(1.9 \pm 0.1 \mathrm{ng} / \mathrm{ml})$. A greater frequency of $\mathrm{LH}$ pulses $(\mathrm{P}<0.05)$ was also observed in OVX (3.0 \pm 0.4 pulses/4h) compared to OVX+E ewes $(1.4 \pm 0.7$ pulses/4h). Amplitude of LH pulses between OVX and OVX+E ewes was not compared because the lack of pulses in 3 of the $6 \mathrm{OVX}+\mathrm{E}$ ewes hindered meaningful analysis.

\section{Distribution of nNOS neurones in the POA and hypothalamus of prepubertal ewes}

Abundant numbers of nNOS neurones were detected in the POA and hypothalamus of prepubertal ewes (Figure 1, 2). Both bipolar and multipolar neurones were observed throughout the continuum of sections, and the distribution of neurones was identical between the OVX and $\mathrm{OVX}+\mathrm{E}$ ewes. In the diagonal band of Broca (DBB), most nNOS neurones were parvocellular ( $\leq 15 \mu \mathrm{m}$ somal diameter) and very lightly stained. Lightly stained fibres were also seen. In

these same sections, darkly stained magnocellular neurones ( $\geq 18 \mu \mathrm{m}$ somal diameter) and fibres were present towards the ventrolateral edge of the section. In the medial septum, darkly stained and mostly magnocellular neurones were noted with relatively sparse fibre labeling. In contrast, densely packed fibres and cells of various sizes were observed in the lateral septum (Figure 1A). 
In the rostral POA, lightly stained parvocellular cells lined the outside edges of the OVLT. Similar to what was observed in sections where the DBB was present, a significant number of darkly stained magnocellular neurones and fibres were noted near the ventrolateral edge of the section (Figure 1B). A few lightly stained cells were also observed in the bed nucleus of the stria terminalis and subfornical organ in these rostral POA sections. In the medial POA, lightly stained parvocellular cells were observed lining the entire length of the third ventricle (Figure 1C, 2A). In some medial POA sections, nNOS neurones were located further away and more lateral to the ventricle (Figure 2A). Small, lightly stained neurones were also evident in the periventricular nucleus $(\mathrm{PeV})$. In the paraventricular nucleus (PVN), both magnocellular and parvocellular neurones were lightly stained (Figure 1D, 1E, 2B). More darkly stained cells were seen on the outer edges of the PVN as well as the areas immediately surrounding it (Figure 1D). Some lightly stained neurones and fibres were also present in the lateral hypothalamic area of these sections. In the dorsomedial hypothalamus, a small number of lightly stained neurones of various sizes, as well as lightly stained fibres, were noted. The greatest number of nNOS neurones was observed in the VL-VMH with a high number of neurones also present in the VMH (Figure 1F, 1G, 2C). Extremely dense fibre labeling was observed in both the VMH and VL-VMH. The larger neurones in these areas were more darkly stained compared to smaller neurones that were a much lighter brown color. At all levels of the ARC, lightly stained neurones and fibres were noted, and there were no observable differences in the number of neurones between the rARC, mARC, and cARC (Figure 1F-H, 2C). Fibres from nNOS neurones were also seen running from the ARC to the internal zone of the median eminence. In the ventral premammillary nucleus (PMv), a majority of the nNOS neurones identified had a bipolar 
orientation. Most of the neurones in this area were moderately stained with nNOS fibres also observed.

\section{Colocalisation of nNOS neurones with ER}

A portion of nNOS neurones in the POA and hypothalamus were found to contain ER $\alpha$ (Figure 3). Of the areas analysed, the highest percentage of nNOS neurones that contained ER $\alpha$ was found in the VL-VMH. However, no significant differences in the percentage of nNOS neurones that contained $\mathrm{ER} \alpha$ were found between the OVX and OVX+E groups in the POA $(19.8 \pm 1.9 \%$ vs. $24.9 \pm 2.1 \%)$, VMH (13.8 $\pm 1.6 \%$ vs. $10.9 \pm 1.1 \%)$, VL-VMH $(45.7 \pm 4.9 \%$ vs. $37.0 \pm 4.0 \%)$, or ARC (29.4 $\pm 2.9 \%$ vs. $29.5 \pm 3.1 \%)$.

The effect of oestradiol on the number of nNOS neurones

The number of nNOS neurones present in the POA, VMH, VL-VMH, and ARC were compared between the OVX and OVX+E groups. No significant differences in the number of nNOS neurones were observed between OVX and OVX+E ewes in the POA (452 \pm 36 vs. $476 \pm$ 33), $\mathrm{VMH}$ (428 \pm 26 vs. $406 \pm 21), \mathrm{VL}-\mathrm{VMH}$ (1,507 \pm 135 vs. $1,541 \pm 130)$, or ARC (205 \pm 10 Vs. $216 \pm 8)$.

\section{Colocalisation of nNOS neurones with kisspeptin}

Analysis of sections labeled for nNOS and kisspeptin revealed that a high percentage of kisspeptin neurones in both the POA and ARC colocalised with nNOS (Figure 4). In the ARC, $98.2 \pm 0.7 \%$ of kisspeptin neurones colocalised with nNOS, and there were no differences between the OVX and OVX+E groups (Table 1). When comparing the OVX and OVX+E 
females, a greater percentage $(\mathrm{P}<0.01)$ of nNOS neurones in OVX ewes $(42.8 \pm 5.2 \%)$

colocalised with kisspeptin compared to OVX+E ewes (21.6 $\pm 3.3 \%)$ in the ARC (Table 1). Few to no kisspeptin neurones were observed in the POA of the OVX group. Therefore, in the POA, the neuroanatomical relationship between nNOS and kisspeptin neurones was only characterised for the OVX+E group. Similar to the ARC, a high percentage (78.9 $\pm 4.9 \%)$ of kisspeptin neurones colocalised with nNOS (Table 1). There was a much higher number of nNOS neurones in the POA than kisspeptin neurones, and as such only $5.4 \pm 1.1 \%$ of nNOS neurones were found to colocalise with kisspeptin.

\section{Colocalisation of nNOS neurones with GnRH}

In the POA of prepubertal ewes, colocalisation between nNOS and GnRH neurones was observed (Figure 5). Overall, it was found that $78.5 \pm 3.7 \%$ of GnRH neurones colocalised with nNOS. There was no difference when comparing OVX and OVX+E ewes (Table 2). Similar to the above data with nNOS and kisspeptin, there were many more nNOS neurones present in the POA than GnRH neurones, and therefore only $4.7 \pm 1.1 \%$ of nNOS neurones colocalised with GnRH. There was no difference in the percentage of nNOS neurones that colocalised with GnRH between the OVX and OVX+E groups (Table 2).

\section{Inputs between kisspeptin and nNOS neurones}

In addition to colocalisation of kisspeptin and nNOS, kisspeptin close-contacts onto nNOS neurones were also examined (Figure 6A). While nNOS close-contacts were seen apposed to kisspeptin neurones, they were not quantified because the punctate nature of the nNOS staining combined with the fact that a high percentage of kisspeptin neurones colocalised with nNOS 
made it difficult to correctly identify what was indeed a nNOS close-contact. Therefore, only kisspeptin close-contacts onto nNOS neurones were analysed (Figure 6A). When comparing the OVX and OVX $+\mathrm{E}$ groups, there was a strong trend $(\mathrm{P}=0.067)$ for nNOS neurones in the ARC of OVX lambs to have a greater number of kisspeptin close-contacts compared to OVX+E lambs (3.2 \pm 0.6 vs. $0.5 \pm 0.2$; Figure $5 B$ ). In contrast to ARC nNOS neurones that exhibited many kisspeptin close-contacts, very few kisspeptin close-contacts onto nNOS neurones were observed in the POA of OVX+E ewes $(0.10 \pm 0.03)$.

\section{Inputs between GnRH and nNOS neurones}

Unlike the kisspeptin innervation that was observed onto nNOS neurones, no GnRH closecontacts were observed onto nNOS neurones in the POA of prepubertal ewes. There were nNOS

close-contacts onto GnRH neurones, but because of the punctate nature of the nNOS staining and high percentage of colocalisation between nNOS and GnRH, nNOS contacts onto GnRH neurones are difficult to accurately identify and as such were not quantified.

\section{DISCUSSION}

In the present study, we characterised for the first time the distribution of nNOS neurones in the POA and hypothalamus of prepubertal ewes and found that a significant proportion of these expressed ER $\alpha$. We also discovered that nNOS was coexpressed to a high degree in GnRH neurones in the POA and in both the ARC and POA population of kisspeptin neurones. As was expected, mean LH concentrations and LH pulse frequency was decreased in OVX+E compared to OVX prepubertal ewes. However, we observed that neither numbers of nNOS neurones in the POA or various other hypothalamic areas nor the percentage of nNOS coexpression with GnRH, 
kisspeptin or ERa were influenced by oestradiol. In addition, kisspeptin close-contacts onto nNOS neurones were observed in the ARC establishing a potentially functional connection between these two neuronal populations.

Because nitric oxide (NO) influences myriad physiological processes within the body (24), including reproduction $(17,18)$, it is not surprising that a large number of nNOS neurones are found in the POA and throughout the hypothalamus of prepubertal ewes. The distribution of nNOS neurones in this study was very similar to what has been previously reported in adult ewes using histochemistry for NADPH diaphorase (NADPHd)(25) which serves as an enzymatic marker for NOS neurones (26). The distribution of nNOS neurones in sheep also compares well to what has previously been described in rats (27), mice (13) nonhuman primates (28), and humans (29). Because NO is a gaseous neurotransmitter with a half-life of around 1 second, cells must be within approximately 100-200 $\mu \mathrm{m}$ of a NO-producing cell in order for NO to exert its effects (30). Thus, because nNOS neurones are so widely and densely distributed throughout the POA and hypothalamus, the potential exists for NO to influence the activity of many cells.

We observed a high degree of ER $\alpha$ expression in nNOS neurones. This is consistent with previous work in rodents, as ER $\alpha$ is found in a high percentage of nNOS/NADPHd neurones in the rat (14-16) and mouse $(13,16)$. Thus, we hypothesized that oestradiol treatment of OVX ewes would alter nNOS expression either generally or in a region-specific manner. However, we did not observe an effect of oestradiol on the number of nNOS neurones present nor the percentage of nNOS neurones that contained ER $\alpha$ in any of the hypothalamic areas examined. In previous work conducted in rodents, treatment of ovariectomised adult rats with oestradiol benzoate using a positive feedback model increased the number of NADPHd-positive neurones in the $\operatorname{VMH}(15,31)$ and medial POA (14). Relatively little work has been done in sheep, but in 
ovariectomised adult ewes, combinatorial insertion of oestradiol and progesterone implants increased the number of NADPHd-positive neurones in the VL-VMH, but not in the POA or ARC (25). It is possible that differences in species, age, or steroid environment of experimental animals may underlie the discrepancies between studies. In sheep, neurones located in the mediobasal hypothalamus, which includes the VMH and VL-VMH, are implicated in the control of estrus behavior (32) and the LH surge (33) both of which are stimulated by highly elevated levels of oestradiol. Therefore, it is possible that the chronic, low levels of oestradiol employed in our study may not have been an appropriate stimulus for eliciting a change in that subset of nNOS neurones.

Neuronal nitric oxide synthase may also act in concert with other neuronal inputs, such as kisspeptin, to influence the initiation of puberty. In adult female mice, kisspeptin fibres are associated with nNOS neurones in the POA and ARC, but only nNOS neurones in the POA express the receptor for kisspeptin, KISS1R (19). In the current study, we also found that nNOS neurones were associated with kisspeptin fibres in the POA and ARC of prepubertal ewes. Notably, nNOS neurones in the ARC exhibited decidedly more kisspeptin close-contacts than nNOS neurones in the POA, and there was a strong trend for oestradiol to decrease the number of kisspeptin close-contacts onto nNOS neurones in the ARC. Further studies are needed to determine if these kisspeptin contacts originate from kisspeptin neurones in the POA or ARC. Regardless, these data may indicate a stronger neuroanatomical relationship between kisspeptin and nNOS in the ARC than in the POA of prepubertal ewes and as such may suggest the ARC is a more important area in which NO may act to influence GnRH secretion. Further studies are needed to determine areas within the hypothalamus that NO may act alone or through kisspeptin to regulate $\mathrm{GnRH} / \mathrm{LH}$ secretion. 
In contrast to what has previously been reported in mice, a high percentage of kisspeptin neurones in both the POA and ARC of prepubertal ewes also coexpressed nNOS. Further, the presence of oestradiol did not influence the percentage of kisspeptin neurones that expressed nNOS in the ARC of prepubertal ewes. However, we noted that oestradiol reduced the percentage of nNOS neurones that coexpressed kisspeptin in the ARC. Because nearly all kisspeptin neurones in the ARC colocalised with nNOS and oestradiol decreases the number of kisspeptin-immunopositive neurones in the ARC of prepubertal ewes $(34,35)$, the difference in the percentage of nNOS neurones coexpressing kisspeptin between OVX and OVX+E ewes is likely due to a decrease in the number of kisspeptin neurones. Thus, the relationship between nNOS and kisspeptin may be expressed in a species-dependent manner. In addition, we cannot rule out age-associated changes, since our sheep were prepubertal but mice from previous work were adults.

In addition to analysing the potential connections between nNOS and kisspeptin, we also examined the neuroanatomical relationship between GnRH and nNOS neurones. We found that a high percentage of GnRH neurones in the POA of prepubertal ewes coexpressed nNOS. This is in contrast to a previous study in rats where it was reported that there was no overlap between GnRH and nNOS expression (36). These results suggest that species variations may exist in nNOS and GnRH coexpression. In addition, we did not observe GnRH-containing contacts onto nNOS neurones. This is consistent with previous work in rodents (36, 37), where GnRH neurones are surrounded by nNOS neurones but, at least in mice, very few close-contacts between the two neuronal populations were observed. These data raise the possibility that nitric oxide synthesized within the POA of prepubertal ewes has the capacity to influence GnRH secretion in an autocrine or paracrine manner. 
In summary, these results illustrate that nNOS-containing neurones are widely distributed throughout the POA and hypothalamus of prepubertal ewes, and these neurones colocalise to a high degree with ER $\alpha$, kisspeptin and GnRH. Furthermore, a neuroanatomical relationship between nNOS and kisspeptin and nNOS and GnRH was established in prepubertal ewes, and the presence of oestradiol had minimal to no effect on the percentage of coexpression or numbers of close-contacts. Altogether, these results suggest the potential for nitric oxide to act both directly and indirectly to influence GnRH secretion in prepubertal ewes.

\section{ACKNOWLEDGEMENTS}

We thank Dr. Miroslav Valent and Gail Sager for their assistance with radioimmunoassays and animal surgeries. We would also like to thank Dr. Margaret Minch and Dr. Jennifer Fridley for veterinary care, and Dr. Al F. Parlow and the National Hormone and Peptide Program for reagents used to measure LH. Imaging experiments and analysis were performed in the West Virginia University Microscope Imaging Facility which is supported by the Mary Babb Randolph Cancer Center and National Institutes of Health Grants P20 RR016440 and P30 RR032138. This work was supported by the National Institute of Food and Agriculture, U.S. Department of Agriculture grant 2013-67015-20956 (SMH) and NIH grant P20GM103434 to the West Virginia IDeA Network for Biomedical Research Excellence.

\section{REFERENCES}

1. Foster DL, Ryan KD. Endocrine mechanisms governing transition into adulthood: a marked decrease in inhibitory feedback action of estradiol on tonic secretion of luteinizing hormone in the lamb during puberty. Endocrinology 1979; 4: 896-904. 
2. Dorling AA, Todman MG, Korach KS, Herbison AE. Critical role for estrogen receptor alpha in negative feedback regulation of gonadotropin-releasing hormone mRNA expression in the female mouse. Neuroendocrinology 2003; 4: 204-209.

3. Lehman MN, Ebling FJ, Moenter SM, Karsch FJ. Distribution of estrogen receptorimmunoreactive cells in the sheep brain. Endocrinology 1993; 2: 876-886.

4. de Roux N, Genin E, Carel JC, Matsuda F, Chaussain JL, Milgrom E. Hypogonadotropic hypogonadism due to loss of function of the KiSS1-derived peptide receptor GPR54. Proc Natl Acad Sci U S A 2003; 19: 10972-10976.

5. Seminara SB, Messager S, Chatzidaki EE, Thresher RR, Acierno JS,Jr, Shagoury JK, BoAbbas Y, Kuohung W, Schwinof KM, Hendrick AG, Zahn D, Dixon J, Kaiser UB, Slaugenhaupt SA, Gusella JF, O'Rahilly S, Carlton MB, Crowley WF,Jr, Aparicio SA, Colledge WH. The GPR54 gene as a regulator of puberty. N Engl J Med 2003; 17: 1614-1627.

6. Topaloglu AK, Tello JA, Kotan LD, Ozbek MN, Yilmaz MB, Erdogan S, Gurbuz F, Temiz F, Millar RP, Yuksel B. Inactivating KISS1 mutation and hypogonadotropic hypogonadism. N Engl J Med 2012; 7: 629-635.

7. Franceschini I, Lomet D, Cateau M, Delsol G, Tillet Y, Caraty A. Kisspeptin immunoreactive cells of the ovine preoptic area and arcuate nucleus co-express estrogen receptor alpha. Neurosci Lett 2006; 3: 225-230. 
8. d'Anglemont de Tassigny X, Ackroyd KJ, Chatzidaki EE, Colledge WH. Kisspeptin signaling is required for peripheral but not central stimulation of gonadotropin-releasing hormone neurons by NMDA. J Neurosci 2010; 25: 8581-8590.

9. Redmond JS, Macedo GG, Velez IC, Caraty A, Williams GL, Amstalden M. Kisspeptin activates the hypothalamic-adenohypophyseal-gonadal axis in prepubertal ewe lambs.

Reproduction 2011; 4: 541-548.

10. Terasawa E, Guerriero KA, Plant TM. Kisspeptin and puberty in mammals. Adv Exp Med Biol 2013; : 253-273.

11. Topaloglu AK, Reimann F, Guclu M, Yalin AS, Kotan LD, Porter KM, Serin A, Mungan NO, Cook JR, Ozbek MN, Imamoglu S, Akalin NS, Yuksel B, O'Rahilly S, Semple RK. TAC3 and TACR3 mutations in familial hypogonadotropic hypogonadism reveal a key role for Neurokinin B in the central control of reproduction. Nat Genet 2009; 3: 354-358.

12. Forstermann U, Schmidt HH, Pollock JS, Sheng H, Mitchell JA, Warner TD, Nakane M, Murad F. Isoforms of nitric oxide synthase. Characterization and purification from different cell types. Biochem Pharmacol 1991; 10: 1849-1857.

13. Chachlaki K, Malone SA, Qualls-Creekmore E, Hrabovszky E, Munzberg H, Giacobini P, Ango F, Prevot V. Phenotyping of nNOS neurons in the postnatal and adult female mouse hypothalamus. J Comp Neurol 2017. 
14. Okamura H, Yokosuka M, Hayashi S. Estrogenic induction of NADPH-diaphorase activity in the preoptic neurons containing estrogen receptor immunoreactivity in the female rat. J Neuroendocrinol 1994; 6: 597-601.

15. Okamura H, Yokosuka M, McEwen BS, Hayashi S. Colocalization of NADPH-diaphorase and estrogen receptor immunoreactivity in the rat ventromedial hypothalamic nucleus: stimulatory effect of estrogen on NADPH-diaphorase activity. Endocrinology 1994; 4: 17051708.

16. Scordalakes EM, Shetty SJ, Rissman EF. Roles of estrogen receptor alpha and androgen receptor in the regulation of neuronal nitric oxide synthase. J Comp Neurol 2002; 4: 336-344.

17. Rettori V, Belova N, Dees WL, Nyberg CL, Gimeno M, McCann SM. Role of nitric oxide in the control of luteinizing hormone-releasing hormone release in vivo and in vitro. Proc Natl Acad Sci U S A 1993; 21: 10130-10134.

18. Gyurko R, Leupen S, Huang PL. Deletion of exon 6 of the neuronal nitric oxide synthase gene in mice results in hypogonadism and infertility. Endocrinology 2002; 7: 2767-2774.

19. Hanchate NK, Parkash J, Bellefontaine N, Mazur D, Colledge WH, d'Anglemont de Tassigny X, Prevot V. Kisspeptin-GPR54 signaling in mouse NO-synthesizing neurons participates in the hypothalamic control of ovulation. J Neurosci 2012; 3: 932-945.

20. Foradori CD, Coolen LM, Fitzgerald ME, Skinner DC, Goodman RL, Lehman MN. Colocalization of progesterone receptors in parvicellular dynorphin neurons of the ovine preoptic area and hypothalamus. Endocrinology 2002; 11: 4366-4374. 
21. Saper CB. An open letter to our readers on the use of antibodies. J Comp Neurol 2005; 4: 477-478.

22. Whisnant CS, Goodman RL. Effects of an opioid antagonist on pulsatile luteinizing hormone secretion in the ewe vary with changes in steroid negative feedback. Biol Reprod 1988; 5: 10321038.

23. Goodman RL, Karsch FJ. Pulsatile secretion of luteinizing hormone: differential suppression by ovarian steroids. Endocrinology 1980; 5: 1286-1290.

24. Garthwaite J. Concepts of neural nitric oxide-mediated transmission. Eur J Neurosci 2008; 11: 2783-2802.

25. Dufourny L, Skinner DC. Influence of estradiol on NADPH diaphorase/neuronal nitric oxide synthase activity and colocalization with progesterone or type II glucocorticoid receptors in ovine hypothalamus. Biol Reprod 2002; 3: 829-836.

26. Dawson TM, Bredt DS, Fotuhi M, Hwang PM, Snyder SH. Nitric oxide synthase and neuronal NADPH diaphorase are identical in brain and peripheral tissues. Proc Natl Acad Sci U S A 1991; 17: 7797-7801.

27. Yamada K, Emson P, Hokfelt T. Immunohistochemical mapping of nitric oxide synthase in the rat hypothalamus and colocalization with neuropeptides. J Chem Neuroanat 1996; 3-4: 295316. 
28. Satoh K, Arai R, Ikemoto K, Narita M, Nagai T, Ohshima H, Kitahama K. Distribution of nitric oxide synthase in the central nervous system of Macaca fuscata: subcortical regions. Neuroscience 1995; 3: 685-696.

29. Sangruchi T, Kowall NW. NADPH diaphorase histochemistry of the human hypothalamus. Neuroscience 1991; 3: 713-724.

30. Thomas D, Flores-Santana W, Switzer C, Wink D, Ridnour L. Determinants of Nitric Oxide Chemistry: Impact of Cell Signaling Processes. In: Ignarro L, ed. Nitric Oxide Biology and Pathobiology. Amsterdam: Elsevier, 2010: 3-18.

31. Rachman IM, Unnerstall JR, Pfaff DW, Cohen RS. Regulation of neuronal nitric oxide synthase mRNA in lordosis-relevant neurons of the ventromedial hypothalamus following shortterm estrogen treatment. Brain Res Mol Brain Res 1998; 1: 105-108.

32. Blache D, Fabre-Nys CJ, Venier G. Ventromedial hypothalamus as a target for oestradiol action on proceptivity, receptivity and luteinizing hormone surge of the ewe. Brain Res 1991; 2: 241-249.

33. Caraty A, Fabre-Nys C, Delaleu B, Locatelli A, Bruneau G, Karsch FJ, Herbison A. Evidence that the mediobasal hypothalamus is the primary site of action of estradiol in inducing the preovulatory gonadotropin releasing hormone surge in the ewe. Endocrinology 1998; 4: 1752-1760. 
34. Nestor CC, Briscoe AM, Davis SM, Valent M, Goodman RL, Hileman SM. Evidence of a role for kisspeptin and neurokinin B in puberty of female sheep. Endocrinology 2012; 6: 27562765.

35. Lopez JA, Bedenbaugh MN, McCosh RB, Weems PW, Meadows LJ, Wisman B, Coolen LM, Goodman RL, Hileman SM. Does Dynorphin Play a Role in the Onset of Puberty in Female Sheep?. J Neuroendocrinol 2016; 12: 10.1111/jne.12445.

36. Herbison AE, Simonian SX, Norris PJ, Emson PC. Relationship of neuronal nitric oxide synthase immunoreactivity to GnRH neurons in the ovariectomized and intact female rat. J Neuroendocrinol 1996; 1: 73-82.

37. Clasadonte J, Poulain P, Beauvillain JC, Prevot V. Activation of neuronal nitric oxide release inhibits spontaneous firing in adult gonadotropin-releasing hormone neurons: a possible local synchronizing signal. Endocrinology 2008; 2: 587-596.

\section{FIGURE LEGENDS}

Figure 1. Drawings illustrating representative distributions of nNOS-IR neurones in the preoptic area and hypothalamus of prepubertal ewes. Each solid black circle represents $10 \mathrm{nNOS}$-IR neurones. The distribution of nNOS-IR neurones was identical on both sides of the POA and hypothalamus and is shown unilaterally to allow for visualization of labels. Ac, anterior commissure; AHA, anterior hypothalamic area; BNST, bed nucleus of the stria terminalis; cARC, caudal arcuate nucleus; mARC, middle arcuate nucleus; rARC, rostral arcuate nucleus; cp, cerebral peduncle; DBB, diagonal band of Broca; DMH, dorsomedial hypothalamus; fx, 
fornix; LHA, lateral hypothalamic area; LS, lateral septum; MS, medial septum; mt, mammillothalamic tract; oc, optic chiasm; ot, optic tract; OVLT, organum vasculosum of lamina terminalis; PMv, ventral premammillary nucleus; POA, preoptic area; PVN, paraventricular nucleus; VMH, ventromedial hypothalamus; VL-VMH, ventrolateral portion of the ventromedial hypothalamus; 3v, third ventricle.

Figure 2. Images demonstrating the distribution of nNOS-immunoreactive neurones and fibres in the preoptic area (A), paraventricular nucleus (B), rostral arcuate nucleus, ventromedial hypothalamus, and ventrolateral portion of the ventromedial hypothalamus (C). Insets in each panel show higher magnification images of nNOS neurones contained in boxes present in each panel. Scale bars in lower magnification images $=500 \mu \mathrm{m}$. Scale bars in higher magnification insets $=50 \mu \mathrm{m}$ fx, fornix; mPOA, medial preoptic area; PVN, paraventricular nucleus; rARC, rostral arcuate nucleus; VL-VMH, ventrolateral portion of the ventromedial hypothalamus; VMH, ventromedial hypothalamus; 3v, third ventricle.

Figure 3. Dual-label detection of nNOS and ER $\alpha$ in the prepubertal ewe. Low magnification image depicting nNOS-immunoreactive neurones (brown) and ER $\alpha$ (black) in the VL-VMH of an OVX+E ewe (A). High magnification image of nNOS neurones shown in box in "A". Black arrow indicates a nNOS neurone that contains ER $\alpha$. White arrow indicates a nNOS neurone that does not contain $E R \alpha$ (B). Scale bar in $A=100 \mu \mathrm{m}$. Scale bar in $B=20 \mu \mathrm{m}$. 
Figure 4. Representative images demonstrating kisspeptin colocalisation with nNOS in the prepubertal ewe. A neurone shown to be expressing nNOS (left), kisspeptin (middle) and the merged image (right) in the ARC of an OVX ewe. Scale bar $=50 \mu \mathrm{m}$.

Figure 5. Representative images demonstrating GnRH colocalisation with nNOS in the POA of a prepubertal ewe. A neurone shown to be expressing nNOS (left), GnRH (middle) and the merged image (right) in the POA of an OVX ewe. Scale bar $=50 \mu \mathrm{m}$.

Figure 6. Kisspeptin close-contacts onto nNOS neurones in the prepubertal ewe. High magnification image showing nNOS (red) neurones with kisspeptin (green) close-contacts (arrows, top neurone) and without kisspeptin close-contacts (bottom neurone) (A). There was a trend for there to be an increased number of kisspeptin close-contacts onto nNOS neurones in OVX compared to OVX+E ewes (B). Scale bar in A $=10 \mu \mathrm{m}$. 
Table 1. Percent colocalisation of kisspeptin and nNOS in prepubertal ewes.

\begin{tabular}{|c|c|c|c|c|c|}
\hline Area & Treatment & $\begin{array}{c}\% \\
\text { Kiss/nNOS }\end{array}$ & $\begin{array}{c}\text { \# Kiss } \\
\text { neurones }\end{array}$ & $\begin{array}{c}\text { \% } \\
\text { nNOS/Kiss }\end{array}$ & $\begin{array}{c}\text { \# nNOS } \\
\text { neurones }\end{array}$ \\
\hline ARC & OVX & $98.5 \pm 1.1$ & $134.3 \pm 14.9^{\mathrm{a}}$ & $42.8 \pm 5.2^{\mathrm{c}}$ & $250.2 \pm 34.3$ \\
\hline ARC & OVX+E & $97.9 \pm 1.1$ & $45.3 \pm 8.7^{\mathrm{b}}$ & $21.6 \pm 3.3^{\mathrm{d}}$ & $208.3 \pm 24.5$ \\
\hline POA & OVX+E & $78.9 \pm 4.9$ & $20.2 \pm 5.3$ & $5.4 \pm 1.1$ & $633.8 \pm 100.6$ \\
\hline
\end{tabular}

Values are expressed at mean \pm SEM. \% Kiss/nNOS; percentage of kisspeptin neurones containing nNOS. \# Kiss neurones; number of kisspeptin neurones per ewe. \% nNOS/Kiss; percentage of nNOS neurones containing kisspeptin. \# nNOS neurones; number of nNOS neurones per ewe. Within column, a, b; c, d differ $(\mathrm{P}<0.01)$.

Table 2. Percent colocalisation of GnRH and nNOS in prepubertal ewes.

\begin{tabular}{|c|c|c|c|c|c|}
\hline \multirow{2}{*}{ Area } & Treatment & $\begin{array}{c}\text { \% } \\
\text { GnRH/nNOS }\end{array}$ & $\begin{array}{c}\text { \# GnRH } \\
\text { neurones }\end{array}$ & $\begin{array}{c}\text { \% } \\
\text { nNOS/GnRH }\end{array}$ & $\begin{array}{c}\text { \# nNOS } \\
\text { neurones }\end{array}$ \\
\hline \multirow{2}{*}{ POA } & OVX & $84.3 \pm 4.6$ & $35.3 \pm 3.4$ & $4.8 \pm 0.7$ & $645.0 \pm 41.1$ \\
\cline { 2 - 6 } & OVX+E & $72.7 \pm 4.9$ & $31.0 \pm 8.1$ & $4.7 \pm 2.3$ & $664.7 \pm 104.7$ \\
\hline
\end{tabular}

Values are expressed at mean \pm SEM. \% GnRH/nNOS; percentage of GnRH neurones

containing nNOS. \# GnRH neurones; number of GnRH neurones per ewe. \% nNOS/GnRH;

percentage of nNOS neurones containing GnRH. \# nNOS neurones; number of nNOS neurones per ewe. 
Figure 1
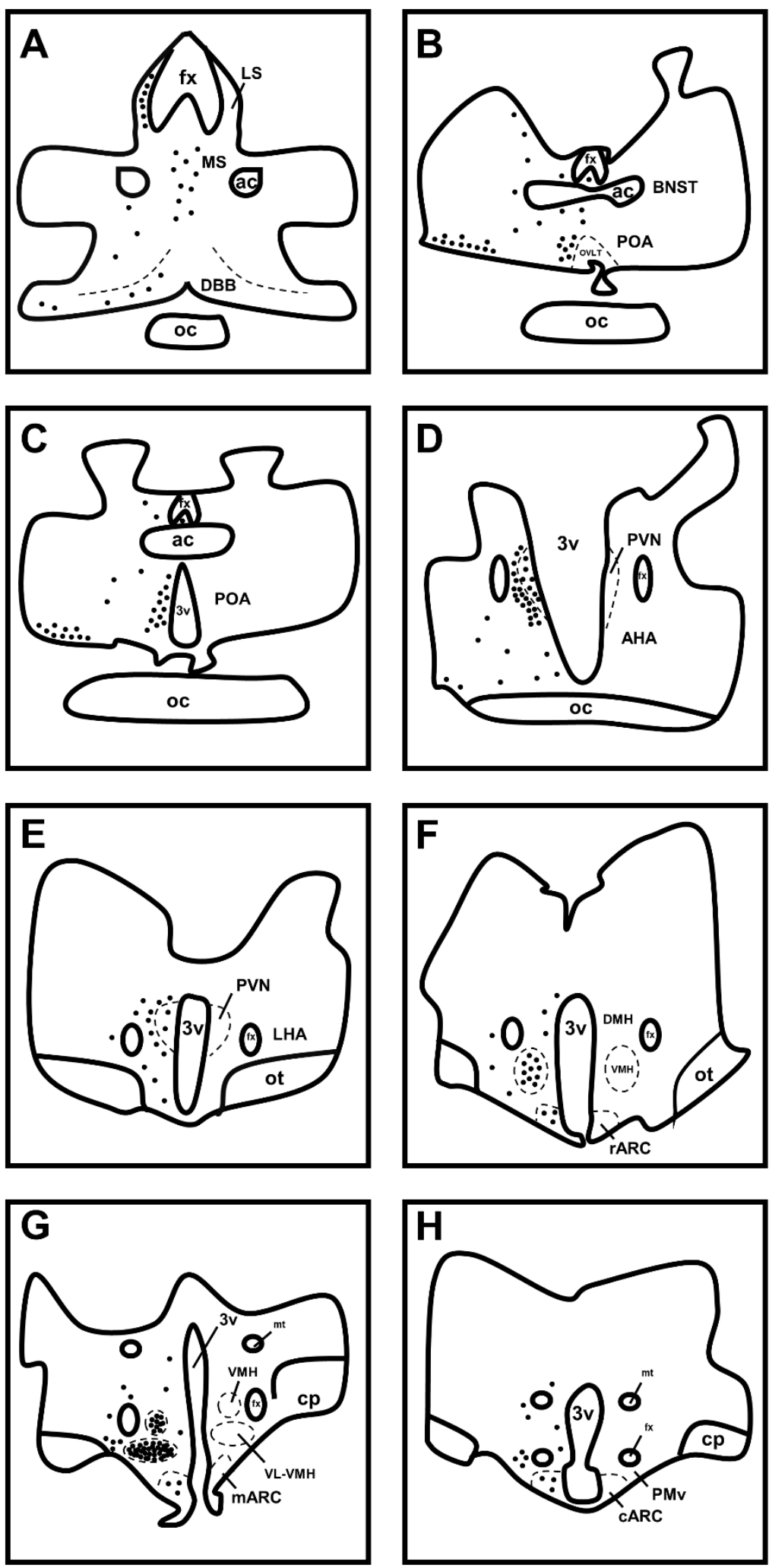
Figure 2




Figure 3

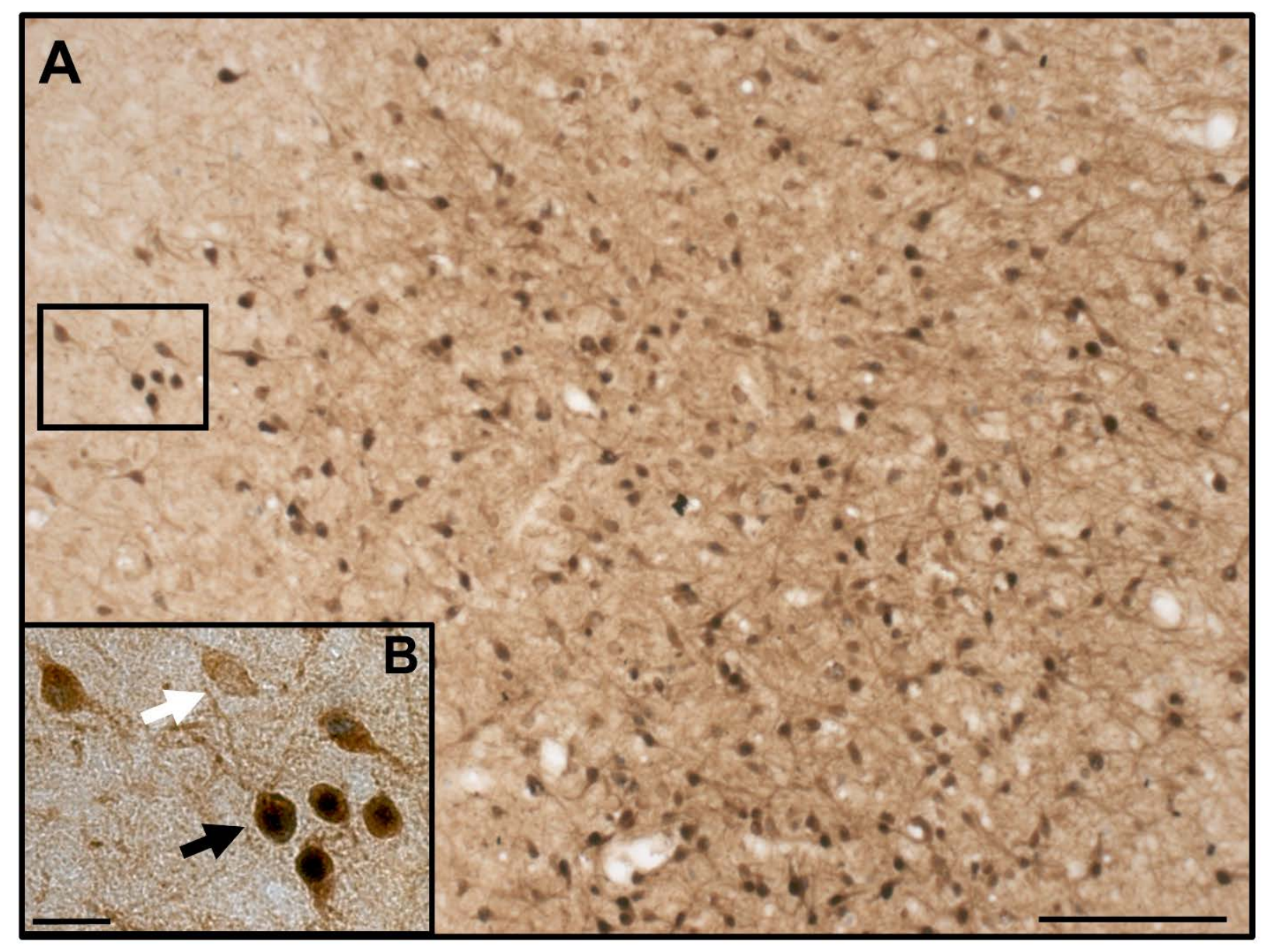


Figure 4

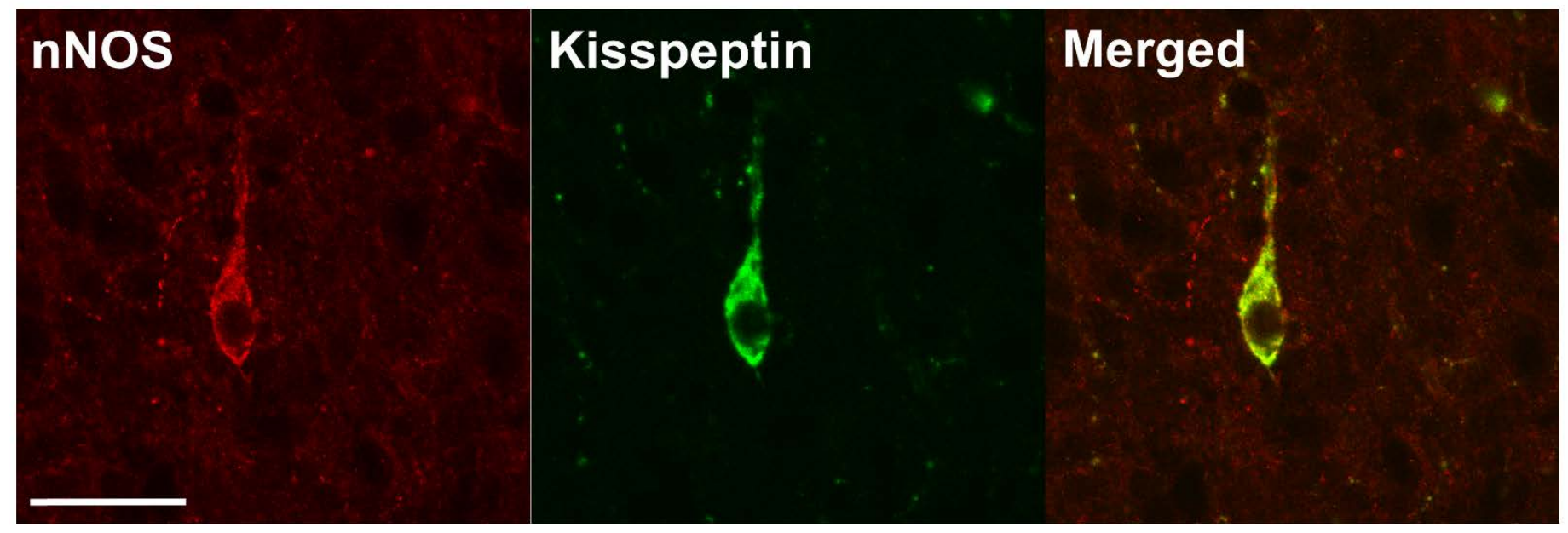


Figure 5

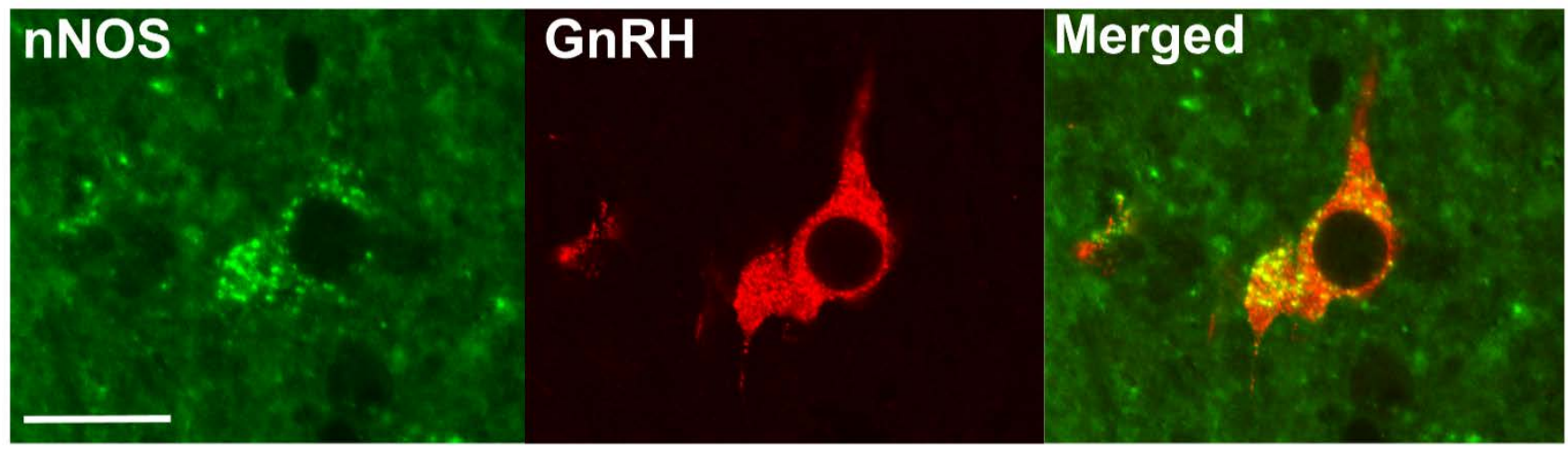


Figure 6

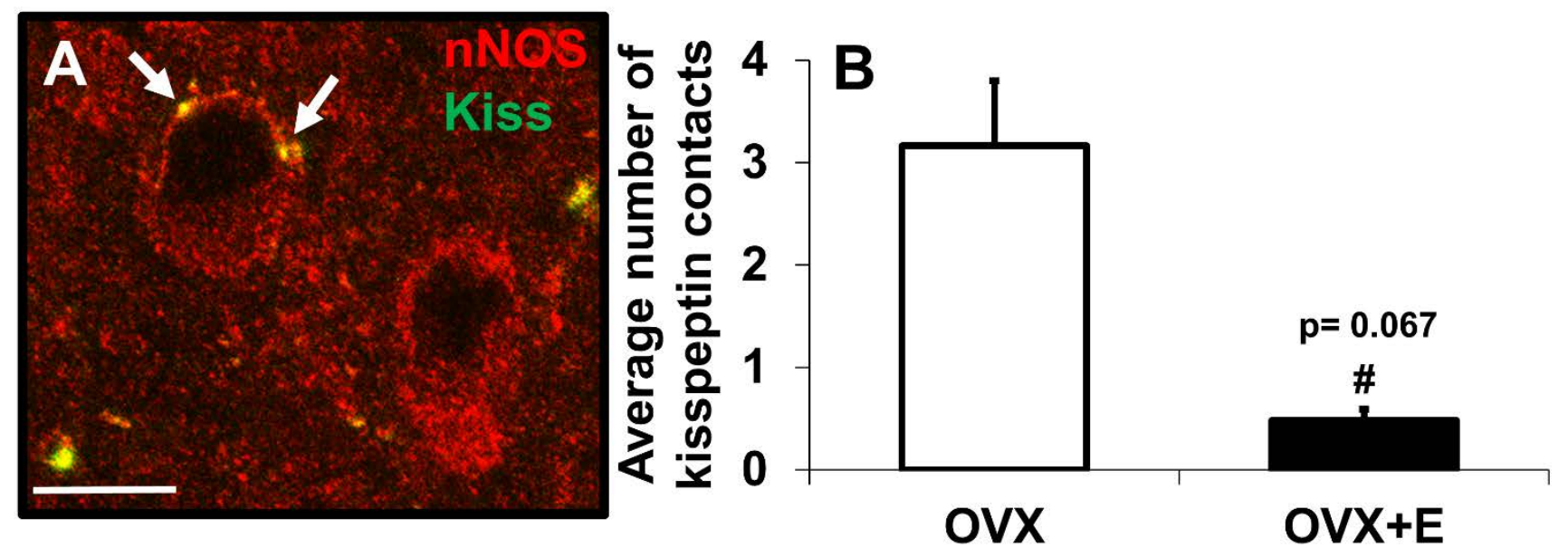




\section{Supplemental Figure 1}

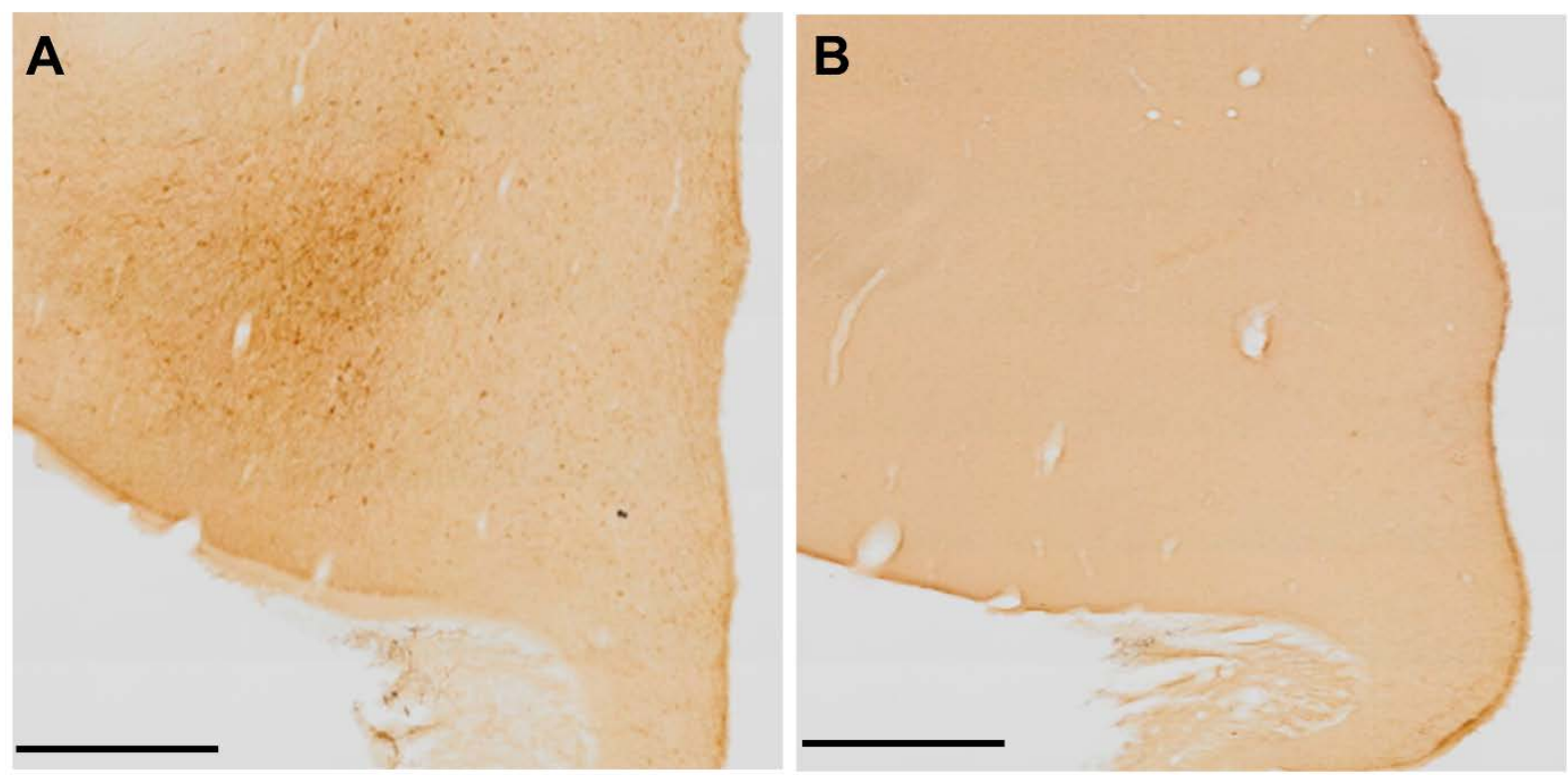

Supplemental Figure 1. nNOS antibody validation in the prepubertal ewe. Low magnification image depicting nNOS-immunoreactive neurones after exposure to rabbit anti-nNOS antibody (A). Low magnification image depicting no nNOS-immunoreactive neurones after exposure to rabbit anti-nNOS antibody that was preadsorbed with nNOS peptide (B.). Scale bars $=500 \mu \mathrm{m}$. 


\section{Supplemental Figure 2}

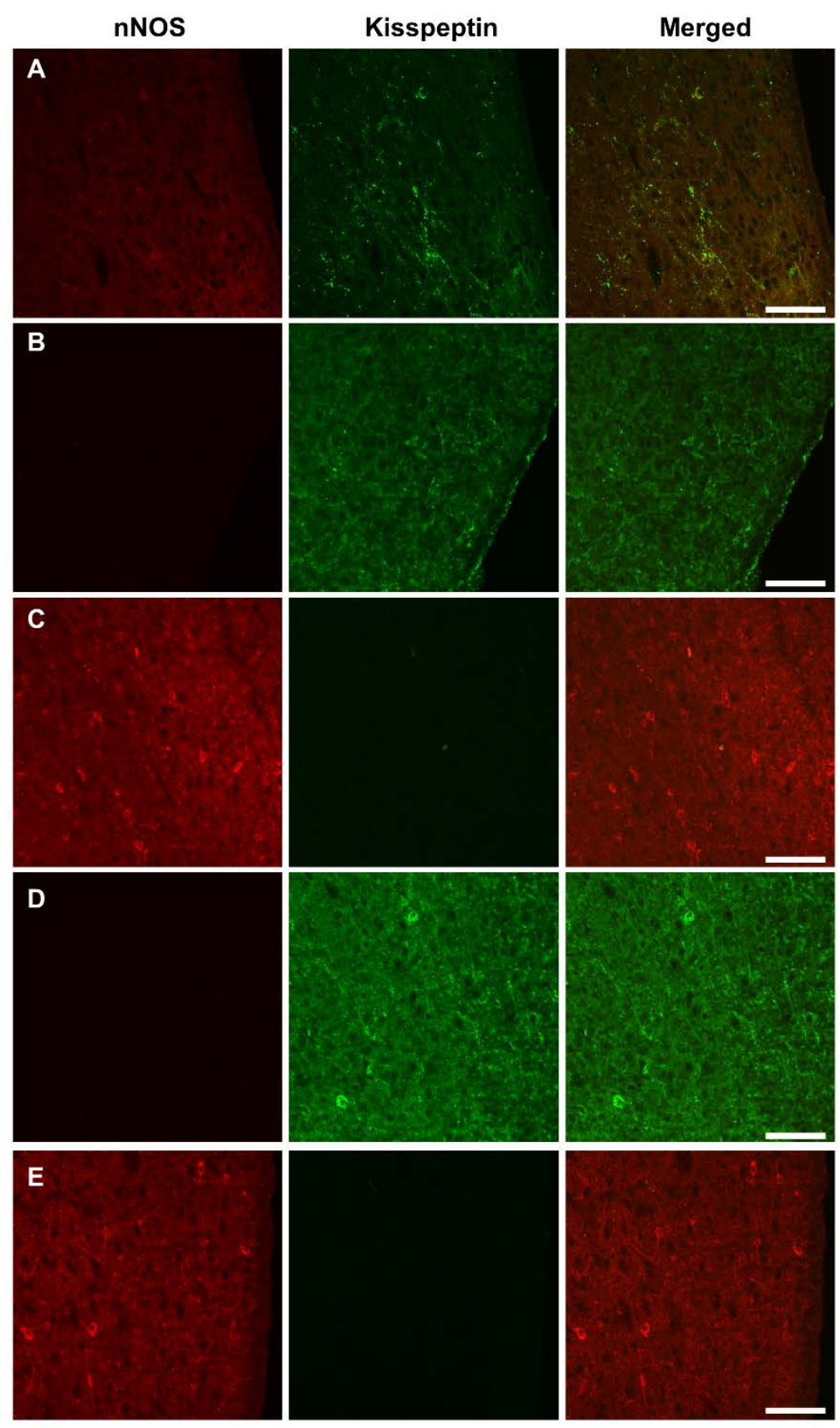

Supplemental Figure 2. Kisspeptin and nNOS immunohistochemistry controls. Positive control (A). Kisspeptin antibody preadsorbed with nNOS peptide (B). nNOS antibody preadsorbed with kisspeptin peptide (C). nNOS antibody omitted (D). Kisspeptin antibody omitted (E). Scale bars $=50 \mu \mathrm{m}$. 


\section{Supplemental Figure 3}

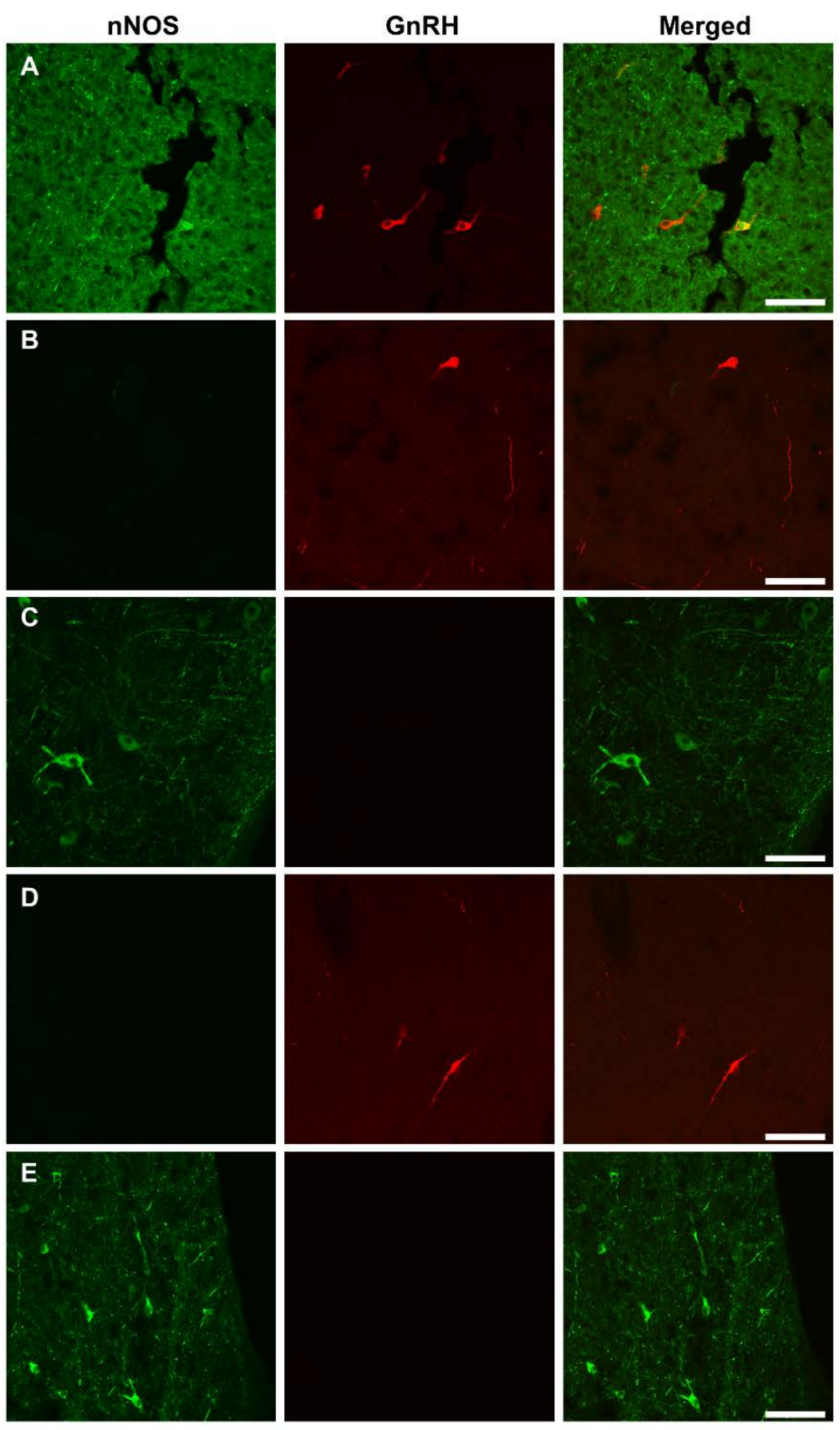

Supplemental Figure 3. GnRH and nNOS immunohistochemistry controls. Positive control (A). GnRH antibody preadsorbed with nNOS peptide (B). nNOS antibody preadsorbed with GnRH peptide (C). nNOS antibody omitted (D). GnRH antibody omitted (E). Scale bars $=50 \mu \mathrm{m}$. 


\section{CHAPTER 4}

\section{NEUROANATOMICAL RELATIONSHIP OF nNOS TO GnRH AND KISSPEPTIN NEURONS IN ADULT FEMALE SHEEP AND PRIMATES}

Michelle N. Bedenbaugh, Richard B. McCosh, Justin A. Lopez, John M. Connors, Robert L.

Goodman, Stanley M. Hileman

Department of Physiology, Pharmacology and Neuroscience, West Virginia University, Morgantown, WV

Abbreviated Title: nNOS, GnRH, and Kisspeptin in adult sheep and primates

Key Terms: GnRH, kisspeptin, nitric oxide, reproduction, hypothalamus 


\section{ABSTRACT}

Neuronal intermediates that communicate estrogen and progesterone feedback to gonadotropin-releasing hormone (GnRH) neurons are essential for modulating reproductive cyclicity. Individually, kisspeptin and nitric oxide (NO) influence GnRH secretion. However, these two neuronal intermediates may also interact with one another to affect reproductive cyclicity. Thus, we investigated the neuroanatomical relationship of one isoform of the enzyme that synthesizes NO, neuronal nitric oxide synthase (nNOS), to kisspeptin and GnRH in adult female rhesus monkeys and sheep. Additionally, we evaluated if the phase of the reproductive cycle would affect these relationships. However, no effect of stage of cycle was observed for any variable in this study. In the arcuate nucleus (ARC) of sheep, $98.8 \pm 3.5 \%$ of kisspeptin neurons colocalized with nNOS, and kisspeptin close-contacts were observed onto nNOS neurons. In contrast to ewes, no colocalization was observed between kisspeptin and nNOS in the ARC of primates, but kisspeptin fibers were apposed to nNOS neurons. In the preoptic area (POA) of ewes, $15.0 \pm 4.2 \%$ of GnRH neurons colocalized with nNOS. In primates, $38.8 \pm 10.1 \%$ of GnRH neurons in the mediobasal hypothalamus (MBH) colocalized with nNOS, and GnRH close-contacts were observed onto nNOS neurons in both sheep and primates. Thus, although species differences were observed, this work establishes a neuroanatomical framework between nNOS and kisspeptin and nNOS and GnRH in adult female nonhuman primates and sheep.

\section{INTRODUCTION}

Gonadotropin-releasing hormone (GnRH) secretion from the hypothalamus is necessary for normal ovarian function and reproductive cyclicity. During the reproductive cycle, the pattern of GnRH secretion from the hypothalamus, and subsequently luteinizing hormone (LH) secretion 
from the anterior pituitary, is modulated by ovarian hormones such as estradiol $\left(\mathrm{E}_{2}\right)$ and progesterone $(1,2)$. However, the effects of either steroid cannot be directly communicated to GnRH neurons because these neurons do not express progesterone receptors or estrogen receptor alpha $(\mathrm{ER} \alpha)$, the estrogen receptor isoform that mediates estrogenic regulation of $\mathrm{GnRH}$ secretion (3-6). Thus, neuronal intermediates that do express these receptors must exist to communicate steroid feedback to GnRH neurons.

Kisspeptin is one such neuropeptide that may mediate the modulation of GnRH secretion by estrogen and progesterone. Kisspeptin was initially discovered to be critical for reproductive function when mutations in the kisspeptin receptor, KISS1R, led to hypogonadotropic hypogonadism and infertility in humans $(7,8)$. Kisspeptin is a potent stimulator of GnRH and LH secretion (9-12), and kisspeptin neurons contain both $\mathrm{ER} \alpha(13,14)$ and progesterone receptors (15). Moreover, GnRH neurons express $\operatorname{KISS1R}(16,17)$ and kisspeptin-containing fibers have been observed in direct apposition to GnRH neurons (18-20). Thus, kisspeptin has the ability to directly communicate the actions of ovarian steroids to GnRH neurons and influence GnRH and LH secretion. However, it is unlikely that kisspeptin is the only neuronal intermediate communicating steroid feedback to GnRH neurons $(21,22)$.

Nitric oxide (NO) is a gaseous neurotransmitter that may also play an important role in regulating GnRH secretion. Neuronal nitric oxide synthase (nNOS) is one of three forms of an enzyme that oxidizes L-arginine and oxygen to L-citrulline and NO (23). In mice (24), rats (25, 26), and sheep (27), a portion of nNOS neurons contain ER $\alpha$. Nitric oxide stimulates GnRH and LH release in rats (28) and deletion of nNOS results in hypogonadism and infertility in mice (29). Recently, evidence that NO release may be influenced directly by kisspeptin has been reported. Kisspeptin close-contacts have been observed onto nNOS neurons in the preoptic area 
(POA) and arcuate nucleus (ARC) of adult female mice, but only nNOS neurons in the POA express KISS1R (30). This indicates there may be a significant degree of interaction between kisspeptin, NO, and GnRH to regulate fertility in rodents.

There is significantly less data regarding this relationship in other species. Kisspeptin closecontacts onto nNOS neurons have also been observed in prepubertal sheep (27). However, in contrast to what is observed in adult rodents $(30,31)$, a high percentage of kisspeptin and $\mathrm{GnRH}$ neurons colocalize with nNOS in the POA and hypothalamus of prepubertal sheep (27). In this

study, we initially characterized the relationship between kisspeptin, nNOS, and GnRH in adult ewes during either the follicular or luteal phase of the estrous cycle. Because we found speciesdependent differences for sheep and rodents, we subsequently evaluated this relationship in female rhesus monkeys during the follicular and luteal phase of the menstrual cycle.

\section{MATERIALS AND METHODS}

\section{$\underline{\text { Animals }}$}

All experiments involving adult sheep were conducted at the West Virginia University Food Animal Research Facility in Morgantown, West Virginia. Procedures were approved by the West Virginia University Animal Care and Use Committee and were performed in accordance with National Institutes of Health guidelines for use of animals in research. Ewes were housed indoors where they received a maintenance diet of commercial premium alfalfa-timothy cube food ration (crude protein $\geq 12 \%$, crude fat $\geq 18 \%$, crude fiber $\leq 32 \%$; Triple Crown Nutrition, Inc., Wayzata, MN, USA) and had free access to water and a mineral block supplement. Experiments were performed during the breeding season in autumn (October). Ewes were housed 2 per pen (6.75 feet x 6.75 feet) on raised flooring with a clear view of all other sheep. 
Indoor lighting simulated the natural changes in day length characteristic of the autumn season. Hypothalamic tissue blocks were collected from 4 ewes in the follicular phase and 4 ewes in the luteal phase of the estrous cycle as described previously (32). Briefly, all sheep were heparinized (20,000 U) and euthanized using an I.V. overdose of sodium pentobarbital (Euthasol; Webster Veterinary, Devens, MA, USA). Heads were removed and perfused via carotid arteries with $6 \mathrm{~L}$ of $4 \%$ paraformaldehyde in $0.1 \mathrm{M}$ phosphate buffer (PB; $\mathrm{pH}$ 7.4) containing $0.1 \%$ sodium nitrite. Blocks of tissue containing the POA and hypothalamus were removed and stored in a $4 \%$ paraformaldehyde solution for $24 \mathrm{~h}$ at $4^{\circ} \mathrm{C}$ and transferred to $20 \%$ sucrose until sectioned. Frozen coronal sections $(45 \mu \mathrm{m})$ were cut with a freezing microtome, collected in 5 series (225 $\mu \mathrm{m}$ apart) and stored in cryopreservative until the time of immunohistochemical staining.

The hypothalami from 4 hysterectomized rhesus monkeys in the follicular phase of the menstrual cycle and 4 hysterectomized rhesus monkeys in the luteal phase of the menstrual cycle that had been collected for other studies were used (33). This tissue was graciously provided by Dr. Tony Plant (University of Pittsburgh, Pittsburgh, Pennsylvania, USA). All monkeys were maintained in accordance with the National Institutes of Health Guidelines for the Care and Use of Laboratory Animals. These monkeys ranged in age from 8-15 years old and weighed 9-11 kg. Tissue was collected post-mortem after serial blood collection and euthanasia with BeuthanasiaD (Henry Schein Animal Health, Dublin, Ohio, USA). Brains were immediately perfused with approximately $1 \mathrm{~L}$ of saline containing $2 \%$ sodium nitrite and 5,000 $\mathrm{U}$ heparin/L followed by approximately $2 \mathrm{~L}$ of $4 \%$ paraformaldehyde in $0.1 \mathrm{M}$ PBS (pH 7.2). After removal of the brain from the cranium, a block of tissue containing the hypothalamus was postfixed in a $4 \%$ paraformaldehyde solution at $4^{\circ} \mathrm{C}$ overnight then transferred to $30 \%$ sucrose until sectioned. 
Frozen sections $(25 \mu \mathrm{m})$ were cut with a freezing microtome, collected in 5 series (125 $\mu \mathrm{m}$ apart) and stored in cryopreservative until the time of immunohistochemical staining.

\section{Dual-label immunofluorescent detection of nNOS and kisspeptin in ewes}

In order to determine if an anatomical relationship existed between nNOS and kisspeptin, 4 hemisections containing the middle to caudal arcuate nucleus (ARC) were selected from 4 follicular phase and 4 luteal phase ewes. On day 1 of the protocol, sections were washed $4 \times 5$ min in $0.1 \mathrm{M}$ phosphate-buffered saline (PBS) to remove excess cryoprotectant and stored overnight at $4^{\circ} \mathrm{C}$. The next day, sections were washed $4 \mathrm{x} 5 \mathrm{~min}$ in PBS, placed in $1 \% \mathrm{H}_{2} \mathrm{O}_{2}$ for 10 min, and subsequently washed 4x5 min in PBS. Tissue was then incubated for at least $1 \mathrm{~h}$ in a blocking solution containing PBS, 0.4\% Triton X-100 (PBSTX; Sigma-Aldrich, St. Louis, MO, USA) and 20\% normal goat serum (NGS; Jackson ImmunoResearch Laboratories, Inc., West Grove, PA, USA). Tissue sections were placed in a solution containing rabbit anti-kisspeptin antiserum (AC566; 1:50,000; INRA, Physiologie de la Reproduction et des Comportements, Nouzilly, France) in PBSTX and 4\% NGS for $16 \mathrm{~h}$. After incubation with the primary antibody, sections were washed and then incubated in a solution containing biotinylated goat anti-rabbit IgG (1:400; Vector Laboratories, Burlingame, CA, USA), PBSTX, and 4\% NGS for $1 \mathrm{~h}$. The sections were washed and incubated in a solution containing avidin-biotin horseradishperoxidase conjugate (Vectastain Elite ABC, 1:600; Vector Laboratories) for $1 \mathrm{~h}$. Sections were then washed and incubated for 10 min in biotinylated tyramine (TSA; 1:250; Perkin Elmer, Waltham, MA, USA) in PBS containing 3\% $\mathrm{H}_{2} \mathrm{O}_{2}$ per $1 \mathrm{~mL}$ of solution. After washing, sections were incubated in a solution containing DyLight green 488-streptavidin (1:200, Fisher Scientific, Pittsburgh, PA, USA) for $1 \mathrm{~h}$ followed by washes and incubation in PBSTX and 4\% NGS for at least $1 \mathrm{~h}$. Sections were incubated in rabbit anti-nNOS antiserum (Cat.\#24287; 1:1,000; 
ImmunoStar antibody, Hudson, WI, USA) in PBSTX, and 4\% NGS for $16 \mathrm{~h}$. The following day, sections were incubated in Alexa555 goat anti-rabbit (1:200; Life Technologies, Carlsbad, CA, USA) for $1 \mathrm{~h}$, washed, mounted on Superfrost slides (Fisher Scientific), coverslipped using Gelvatol and stored in the dark at $4^{\circ} \mathrm{C}$ until analysis.

\section{Dual-label immunofluorescent detection of nNOS and GnRH in ewes}

To detect nNOS and GnRH neurons in ewes, the same protocol as above was used with minor changes. The rabbit anti-nNOS antiserum (Immunostar) was the TSA-amplified primary antibody and was therefore used at a concentration of 1:10,000. Rabbit anti-GnRH antiserum (Cat.\#20075, Immunostar) was used at a concentration of 1:200. This protocol was used to stain 4 POA sections from 4 follicular phase and 4 luteal phase ewes.

Dual-label immunofluorescent detection of nNOS and kisspeptin in female rhesus monkeys

In order to determine if a neuroanatomical relationship existed between nNOS and kisspeptin in nonhuman primates, 4 hemisections containing the middle to caudal ARC were selected from 4 follicular phase and 4 luteal phase female rhesus monkeys. This dual-label immunofluorescent protocol was identical to that described for use in ewes with a few exceptions. Normal donkey serum (NDS) was used instead of NGS, and NDS was used at a concentration of $10 \%$ instead of $20 \%$ in the blocking incubation step. Tissue sections were incubated in both sheep antikisspeptin antiserum (GQ2; 1:20,000), kindly provided by Dr. Stephen Bloom (Imperial College London, Hammersmith Hospital, London, UK) and rabbit anti-nNOS antiserum (1:5,000, Immunostar) for $16 \mathrm{~h}$ in PBSTX with 4\% NDS. Biotinylated horse anti-rabbit IgG (Vector Laboratories) was used instead of biotinylated goat anti-rabbit IgG and Alexa 555 donkey antisheep (Life Technologies) was used in place of Alexa 555 goat anti-rabbit.

Dual-label immunofluorescent detection of nNOS and GnRH in female rhesus monkeys 
To detect nNOS and GnRH immunopositive neurons, every other hemisection from one complete series of sections throughout the mediobasal hypothalamus (MBH) from 4 follicular phase and 4 luteal phase female rhesus monkeys was used. The staining protocol was identical to the previous procedure described above for detecting nNOS and kisspeptin in female rhesus monkeys with a few exceptions. Instead of tissue sections being incubated in both primary antibodies at the same time, sections were first incubated in a solution containing rabbit antinNOS antiserum (1:5,000, Immunostar) in PBSTX and 4\% NDS for $16 \mathrm{~h}$ followed by incubation in rabbit anti-GnRH antiserum (LR-1; 1:100,000) kindly provided by Dr. Robert Benoit (Montreal General Hospital, Montreal, Quebec, Canada) at the end of the next day of the protocol. To detect GnRH neurons, sections were also incubated in Alexa 555 donkey antirabbit (Life Technologies) instead of Alexa 555 donkey anti-sheep.

\section{$\underline{\text { Immunohistochemistry Controls }}$}

Specificity of the nNOS antibody in primate tissue was tested using recommended controls for immunostaining including peptide blocking controls and primary antibody omission controls (34). These controls abolished all nNOS staining (Supplemental Figure 1). In addition, controls in which antibodies were incubated with the opposite peptide used in the staining protocol or primary antibodies were omitted were utilized to demonstrate that no cross-reactivity occurred between any of the antibodies used in these experiments. Images of these controls for primate tissue can be found in Supplemental Figures 2 and 3. Controls for all antibodies used in sheep have been reported previously (27).

\section{Data Analysis}

Immunohistochemistry 
The number of kisspeptin close-contacts onto nNOS neurons in both sheep and primates was determined by capturing images of 10 nNOS neurons in the ARC of each animal using a LSM 510 laser scanning confocal system (Zeiss, Thornwood, NY, USA) on a Zeiss Axio Image Z1 upright microscope with a Plan Apochromat x 63/1.4 oil objective. Confocal z-stacks of optical sections were taken at $1 \mu \mathrm{m}$ intervals through each nNOS neuron. The number of close-contacts onto nNOS cell bodies was analyzed using ZEN software (Zeiss). Because contacts were counted through the entire z-stack, markers were placed on each individual contact to ensure that no contacts were counted more than once. Orthogonal views were used to confirm that contacts were touching the cell in all planes. The same approach was also used to identify the number of GnRH close-contacts onto nNOS neurons in the POA of ewes and MBH of female rhesus monkeys.

Using the same images that were captured to determine the number of kisspeptin closecontacts onto nNOS neurons in the ARC, the percentage of kisspeptin and nNOS neurons that were colocalized was identified in 10 kisspeptin neurons and 10 nNOS neurons in the ARC of each animal. The same procedure was used to determine the percentage of GnRH and nNOS neurons that were colocalized in $10 \mathrm{GnRH}$ and 10 nNOS neurons in the POA of ewes and $\mathrm{MBH}$ of female rhesus monkeys.

\section{Statistical Analysis}

The percent colocalization between nNOS and kisspeptin and nNOS and GnRH neurons, the percentage of nNOS neurons that exhibited at least one kisspeptin close-contact, and the percentage of nNOS neurons that exhibited at least one GnRH close-contact was analyzed via chi-squared analysis. The number of kisspeptin and GnRH close-contacts were transformed to 
normalize variance using the square root and compared by t-test. $\mathrm{P}<0.05$ was considered statistically significant.

\section{RESULTS}

Neuroanatomical relationship between kisspeptin and nNOS in sheep

In ewes, a high percentage of kisspeptin neurons $(98.8 \pm 3.5 \%)$ in the ARC colocalized with nNOS regardless of whether ewes were in the follicular or luteal phase of the estrous cycle (Figure 1A-D). Similarly, there was no difference in the percentage of nNOS neurons that colocalized with kisspeptin in the ARC of follicular $(50.0 \pm 7.1 \%)$ or luteal $(52.5 \pm 4.8 \%)$ phase ewes. Moreover, kisspeptin close-contacts were observed onto nNOS neurons in the ARC (Figure 1E-G). There was no difference in the percentage of nNOS neurons that exhibited at least one kisspeptin close-contact between follicular $(85.0 \pm 6.5 \%)$ and luteal $(77.5 \pm 8.5 \%)$ phase ewes. Additionally, the mean number of kisspeptin close-contacts onto nNOS neurons was similar between follicular $(4.0 \pm 0.4)$ and luteal $(4.0 \pm 0.7)$ phase ewes.

\section{Neuroanatomical relationship between GnRH and nNOS in sheep}

In addition to nNOS being colocalized with kisspeptin, nNOS was also colocalized with GnRH in adult ewes (Figure 2A-D). In the POA, $15.0 \pm 4.2 \%$ of GnRH neurons expressed nNOS, and phase of the estrous cycle had no effect. Furthermore, $3.8 \pm 1.8 \%$ of nNOS neurons colocalized with GnRH in the POA of adult ewes, and there was no difference between follicular and luteal phase ewes. Neuronal NOS neurons in the POA exhibited GnRH close-contacts (Figure 2E-G), but there was no difference in the percentage of nNOS neurons that exhibited at least one GnRH close-contact between follicular (37.5 \pm 8.5\%) and luteal (30.0 $\pm 17.8 \%)$ phase 
ewes. The mean number of GnRH close-contacts onto nNOS neurons was also similar between follicular ( $3.0 \pm 1.0)$ and luteal $(2.8 \pm 1.4)$ phase ewes.

\section{Neuroanatomical relationship between kisspeptin and nNOS in primates}

In contrast to what was observed in ewes, no colocalization was observed between kisspeptin and nNOS neuronal populations present in the ARC of adult female rhesus monkeys (Figure 3A, B). However, kisspeptin close-contacts were observed onto nNOS neurons (Figure 3C). The percentage of nNOS neurons that exhibited at least one kisspeptin close-contact was similar between follicular $(72.5 \pm 7.5 \%)$ and luteal phase monkeys ( $87.5 \pm 9.5 \%)$. No differences in the average number of kisspeptin close-contacts existed between follicular (6.3 \pm 1.3$)$ and luteal phase monkeys (3.6 \pm 0.5$)$.

\section{Neuroanatomical relationship between GnRH and nNOS in primates}

In contrast to the absence of colocalization between kisspeptin and nNOS in the ARC of adult female primates, GnRH and nNOS in the MBH were colocalized (Figure 4A-D). There was no significant difference between the percentage of GnRH neurons that colocalized with nNOS in the follicular (35.0 $\pm 13.2 \%$ ) and luteal phase groups ( $42.5 \pm 17.0 \%)$. Similar to what was observed in ewes, a lower percentage of nNOS neurons colocalized with GnRH than GnRH neurons with nNOS. However, there was a considerable amount of variability between females, and there was no difference in the percentage of nNOS neurons that colocalized with GnRH between the follicular $(17.5 \pm 8.5 \%)$ and luteal phase groups $(10.0 \pm 9.0 \%)$. A comparison of the percent colocalization between nNOS and kisspeptin and nNOS and GnRH in sheep and primates can be found in Table 1. GnRH close-contacts were apparent on nNOS neurons in the 
MBH (Figure 4E-G). There was no difference in the percentage of nNOS neurons that exhibited at least one GnRH close-contact between follicular (22.5 $\pm 8.5 \%)$ and luteal (30.0 $\pm 14.1 \%)$ phase monkeys. Additionally, the mean number of GnRH close-contacts onto nNOS neurons was similar between the follicular $(4.9 \pm 2.9)$ and luteal phase groups $(2.6 \pm 0.4)$.

\section{DISCUSSION}

In the present study, we describe for the first time the neuroanatomical relationship between nNOS and kisspeptin and nNOS and GnRH in adult female rhesus monkeys and ewes. In both ewes and female rhesus monkeys, a subset of GnRH neurons colocalized with nNOS. Additionally, GnRH and kisspeptin close-contacts were observed onto nNOS neurons in both species, and in the ARC of ewes a high percentage of kisspeptin neurons colocalized with nNOS. In contrast, we did not observe any colocalization between kisspeptin and nNOS in adult female rhesus monkeys.

In a previous study conducted in adult female mice, kisspeptin fibers were found apposed to nNOS neurons in both the POA and ARC. However, only nNOS neurons in the POA expressed the receptor for kisspeptin, KISS1R, suggesting nNOS neurons in the POA and not the ARC of mice can be directly affected by kisspeptin (30). In prepubertal sheep, kisspeptin close-contacts were also found on nNOS neurons in both the POA and ARC, but whether nNOS neurons expressed KISS1R was not examined in that study. Moreover, nNOS neurons in the ARC exhibited more kisspeptin close-contacts than nNOS neurons in the POA, and there was a strong trend for $\mathrm{E}_{2}$ to decrease the number of kisspeptin close-contacts onto nNOS neurons in the ARC (27). In the present study, kisspeptin close-contacts were also associated with nNOS neurons in the ARC of follicular and luteal phase rhesus monkeys and ewes, but there was no effect of 
phase of cycle on the number of kisspeptin close-contacts onto nNOS neurons. Thus, kisspeptin input to nNOS neurons may not be sensitive to fluctuations in sex steroids in adult female rhesus monkeys or ewes. Sex steroids may also influence other functionally important changes between kisspeptin and nNOS besides the number of close-contacts. In mice, injections of kisspeptin increase the phosphorylation, and thus catalytic activity, of nNOS (30). The release of kisspeptin or NO may also be affected by concentrations of sex steroids, since $\mathrm{E}_{2}$ is known to individually modulate kisspeptin and nNOS signaling and expression (19, 30, 35-38). Further studies are needed to determine if this is indeed the case in sheep or primates.

In the ARC of adult ewes, $99 \%$ of kisspeptin neurons also contained nNOS. This is consistent with our previous results in prepubertal ewes (27). Therefore, at least in the ARC, transitioning from a prepubertal to an adult state does not appear to affect the percentage of kisspeptin neurons that colocalize with nNOS in sheep. Moreover, fluctuations in sex steroids do not seem to influence kisspeptin and nNOS colocalization, as there were no differences observed between follicular and luteal phase ewes. Unlike what was observed in sheep, no colocalization was observed between kisspeptin and nNOS in the ARC of primates. These results are much more akin to what has been reported for mice, i.e. virtually no colocalization in either the POA or ARC (30). Thus, the relationship between nNOS and kisspeptin appears to be species dependent.

In addition to analyzing the potential connections between nNOS and kisspeptin, we also examined the neuroanatomical relationship between GnRH and nNOS neurons. In both female rhesus monkeys and ewes, GnRH close-contacts onto nNOS neurons were observed, and similar to results discussed above, phase of cycle had no effect on the number of GnRH contacts onto nNOS neurons. In adult ewes, $15 \%$ of GnRH neurons in the POA colocalized with nNOS. 
Interestingly, this percentage is markedly lower than what has been observed in prepubertal ewes where $79 \%$ of GnRH neurons in the POA colocalized with nNOS (27). Therefore, it appears colocalization between GnRH and nNOS may decrease as ewes mature from a prepubertal to an adult state. In contrast to results in ewes, no colocalization is observed between nNOS and GnRH neurons in adult mice and rats $(31,39)$. However, similar to what was observed in adult ewes, 39\% of GnRH neurons in adult female rhesus monkeys colocalized with nNOS in the MBH. Therefore, large species variations appear to exist in nNOS and GnRH coexpression. Additional functional studies are needed to determine how NO acts in both adult female rhesus monkeys and ewes to influence GnRH neuronal activity and GnRH secretion.

In summary, these results establish a neuroanatomical relationship between nNOS and kisspeptin and nNOS and GnRH in adult female rhesus monkeys and ewes. The phase of the estrous or menstrual cycle had no effect on the percentage of coexpression or numbers of closecontacts of any neuronal populations. Altogether, these results suggest that nitric oxide may act both directly and indirectly to influence GnRH secretion in female adult rhesus monkeys and ewes.

\section{ACKNOWLEDGEMENTS}

We thank Dr. Miroslav Valent and Gail Sager for their assistance with animal handling and tissue collection from ewes. We would also like to thank Dr. Margaret Minch and Dr. Jennifer Fridley for veterinary care, Dr. Tony Plant and Dr. Suresh Ramaswamy (University of Pittsburgh, Pittsburgh, Pennsylvania, USA) for providing primate tissue, Dr. Al F. Parlow and the National Hormone and Peptide Program for reagents used to measure LH, Dr. Stephen R. Bloom (Imperial College London, London, UK) for the kisspeptin antibody used for primate 
tissue staining protocols, Dr. Robert Benoit (Montreal General Hospital, Montreal, Quebec, Canada) for the GnRH antibody used for primate tissue staining protocols, and Dr. Isabelle Franceschini (INRA, Physiologie de la Reproduction et des Comportements, Nouzilly, France) for the kisspeptin antibody used for sheep tissue staining protocols. Imaging experiments and analysis were performed in the West Virginia University Microscope Imaging Facility which is supported by the Mary Babb Randolph Cancer Center and National Institutes of Health Grants P20 RR016440 and P30 RR032138. This work was supported by the National Institute of Food and Agriculture, U.S. Department of Agriculture grant 2013-67015-20956 (SMH) and NIH grant P20GM103434 to the West Virginia IDeA Network for Biomedical Research Excellence.

\section{REFERENCES}

1. Goodman RL, Inskeep EK. Control of the Ovarian Cycle of the Sheep. In: Plant TM and Zeleznik AJ, eds. Knobil and Neill's Physiology of Reproduction. London: Elsevier, 2015: 12591305.

2. Zeleznik A, Plant T. Control of the Menstrual Cycle. In: Zeleznik A and Plant T, eds. Knobil and Neill's Physiology of Reproduction, 2015: 1307-1348.

3. Lehman MN, Karsch FJ. Do gonadotropin-releasing hormone, tyrosine hydroxylase-, and beta-endorphin-immunoreactive neurons contain estrogen receptors? A double-label immunocytochemical study in the Suffolk ewe. Endocrinology 1993; 2: 887-895.

4. Herbison AE, Robinson JE, Skinner DC. Distribution of estrogen receptor-immunoreactive cells in the preoptic area of the ewe: co-localization with glutamic acid decarboxylase but not luteinizing hormone-releasing hormone. Neuroendocrinology 1993; 4: 751-759. 
5. Skinner DC, Caraty A, Allingham R. Unmasking the progesterone receptor in the preoptic area and hypothalamus of the ewe: no colocalization with gonadotropin-releasing neurons. Endocrinology 2001; 2: 573-579.

6. Sullivan KA, Witkin JW, Ferin M, Silverman AJ. Gonadotropin-releasing hormone neurons in the rhesus macaque are not immunoreactive for the estrogen receptor. Brain Res 1995; 1-2: 198200.

7. Seminara SB, Messager S, Chatzidaki EE, Thresher RR, Acierno JS,Jr, Shagoury JK, BoAbbas Y, Kuohung W, Schwinof KM, Hendrick AG, Zahn D, Dixon J, Kaiser UB, Slaugenhaupt SA, Gusella JF, O'Rahilly S, Carlton MB, Crowley WF,Jr, Aparicio SA, Colledge WH. The GPR54 gene as a regulator of puberty. N Engl J Med 2003; 17: 1614-1627.

8. de Roux N, Genin E, Carel JC, Matsuda F, Chaussain JL, Milgrom E. Hypogonadotropic hypogonadism due to loss of function of the KiSS1-derived peptide receptor GPR54. Proc Natl Acad Sci U S A 2003; 19: 10972-10976.

9. Redmond JS, Macedo GG, Velez IC, Caraty A, Williams GL, Amstalden M. Kisspeptin activates the hypothalamic-adenohypophyseal-gonadal axis in prepubertal ewe lambs.

Reproduction 2011; 4: 541-548.

10. Merkley CM, Porter KL, Coolen LM, Hileman SM, Billings HJ, Drews S, Goodman RL, Lehman MN. KNDy (Kisspeptin/Neurokinin B/Dynorphin) Neurons Are Activated during Both Pulsatile and Surge Secretion of LH in the Ewe. Endocrinology 2012; 11: 5406-5414. 
11. Messager S, Chatzidaki EE, Ma D, Hendrick AG, Zahn D, Dixon J, Thresher RR, Malinge I, Lomet D, Carlton MB, Colledge WH, Caraty A, Aparicio SA. Kisspeptin directly stimulates gonadotropin-releasing hormone release via G protein-coupled receptor 54. Proc Natl Acad Sci U S A 2005; 5: 1761-1766.

12. Shahab M, Mastronardi C, Seminara SB, Crowley WF, Ojeda SR, Plant TM. Increased hypothalamic GPR54 signaling: a potential mechanism for initiation of puberty in primates. Proc Natl Acad Sci U S A 2005; 6: 2129-2134.

13. Franceschini I, Lomet D, Cateau M, Delsol G, Tillet Y, Caraty A. Kisspeptin immunoreactive cells of the ovine preoptic area and arcuate nucleus co-express estrogen receptor alpha. Neurosci Lett 2006; 3: 225-230.

14. Bedenbaugh MN, D'Oliveira M, Cardoso RC, Hileman SM, Williams GL, Amstalden M. Pubertal escape from estradiol negative feedback in ewe lambs is not accounted for by decreased ESR1 mRNA or protein in kisspeptin neurons. Endocrinology 2017.

15. Smith JT, Clay CM, Caraty A, Clarke IJ. KiSS-1 messenger ribonucleic acid expression in the hypothalamus of the ewe is regulated by sex steroids and season. Endocrinology 2007; 3: $1150-1157$.

16. Han SK, Gottsch ML, Lee KJ, Popa SM, Smith JT, Jakawich SK, Clifton DK, Steiner RA, Herbison AE. Activation of gonadotropin-releasing hormone neurons by kisspeptin as a neuroendocrine switch for the onset of puberty. J Neurosci 2005; 49: 11349-11356. 
17. Herbison AE, de Tassigny X, Doran J, Colledge WH. Distribution and postnatal development of Gpr54 gene expression in mouse brain and gonadotropin-releasing hormone neurons. Endocrinology 2010; 1: 312-321.

18. Clarkson J, Herbison AE. Postnatal development of kisspeptin neurons in mouse hypothalamus; sexual dimorphism and projections to gonadotropin-releasing hormone neurons. Endocrinology 2006; 12: 5817-5825.

19. Nestor CC, Briscoe AM, Davis SM, Valent M, Goodman RL, Hileman SM. Evidence of a role for kisspeptin and neurokinin B in puberty of female sheep. Endocrinology 2012; 6: 27562765.

20. Merkley CM, Coolen LM, Goodman RL, Lehman MN. Evidence for changes in numbers of synaptic inputs onto KNDy and GnRH neurones during the preovulatory LH surge in the ewe. J Neuroendocrinol 2015.

21. Terasawa E, Guerriero KA, Plant TM. Kisspeptin and puberty in mammals. Adv Exp Med Biol 2013; : 253-273.

22. Topaloglu AK, Reimann F, Guclu M, Yalin AS, Kotan LD, Porter KM, Serin A, Mungan NO, Cook JR, Ozbek MN, Imamoglu S, Akalin NS, Yuksel B, O'Rahilly S, Semple RK. TAC3 and TACR3 mutations in familial hypogonadotropic hypogonadism reveal a key role for Neurokinin B in the central control of reproduction. Nat Genet 2009; 3: 354-358. 
23. Forstermann U, Schmidt HH, Pollock JS, Sheng H, Mitchell JA, Warner TD, Nakane M, Murad F. Isoforms of nitric oxide synthase. Characterization and purification from different cell types. Biochem Pharmacol 1991; 10: 1849-1857.

24. Scordalakes EM, Shetty SJ, Rissman EF. Roles of estrogen receptor alpha and androgen receptor in the regulation of neuronal nitric oxide synthase. J Comp Neurol 2002; 4: 336-344.

25. Okamura H, Yokosuka M, McEwen BS, Hayashi S. Colocalization of NADPH-diaphorase and estrogen receptor immunoreactivity in the rat ventromedial hypothalamic nucleus: stimulatory effect of estrogen on NADPH-diaphorase activity. Endocrinology 1994; 4: 17051708.

26. Okamura H, Yokosuka M, Hayashi S. Estrogenic induction of NADPH-diaphorase activity in the preoptic neurons containing estrogen receptor immunoreactivity in the female rat. $\mathrm{J}$ Neuroendocrinol 1994; 6: 597-601.

27. Bedenbaugh MN, O'Connell RC, Lopez JA, McCosh RB, Goodman RL, Hileman SM. Kisspeptin, GnRH, and ERalpha colocalise with nNOS neurones in prepubertal female sheep. J Neuroendocrinol 2017.

28. Rettori V, Belova N, Dees WL, Nyberg CL, Gimeno M, McCann SM. Role of nitric oxide in the control of luteinizing hormone-releasing hormone release in vivo and in vitro. Proc Natl Acad Sci U S A 1993; 21: 10130-10134.

29. Gyurko R, Leupen S, Huang PL. Deletion of exon 6 of the neuronal nitric oxide synthase gene in mice results in hypogonadism and infertility. Endocrinology 2002; 7: 2767-2774. 
30. Hanchate NK, Parkash J, Bellefontaine N, Mazur D, Colledge WH, d'Anglemont de Tassigny X, Prevot V. Kisspeptin-GPR54 signaling in mouse NO-synthesizing neurons participates in the hypothalamic control of ovulation. J Neurosci 2012; 3: 932-945.

31. Herbison AE, Simonian SX, Norris PJ, Emson PC. Relationship of neuronal nitric oxide synthase immunoreactivity to GnRH neurons in the ovariectomized and intact female rat. J Neuroendocrinol 1996; 1: 73-82.

32. Foradori CD, Coolen LM, Fitzgerald ME, Skinner DC, Goodman RL, Lehman MN. Colocalization of progesterone receptors in parvicellular dynorphin neurons of the ovine preoptic area and hypothalamus. Endocrinology 2002; 11: 4366-4374.

33. Vargas Trujillo M, Kalil B, Ramaswamy S, Plant TM. Estradiol Upregulates Kisspeptin Expression in the Preoptic Area of both the Male and Female Rhesus Monkey (Macaca mulatta): Implications for the Hypothalamic Control of Ovulation in Highly Evolved Primates. Neuroendocrinology 2017; 1: 77-89.

34. Saper CB. An open letter to our readers on the use of antibodies. J Comp Neurol 2005; 4: 477-478.

35. d'Anglemont de Tassigny X, Campagne C, Dehouck B, Leroy D, Holstein GR, Beauvillain JC, Buee-Scherrer V, Prevot V. Coupling of neuronal nitric oxide synthase to NMDA receptors via postsynaptic density-95 depends on estrogen and contributes to the central control of adult female reproduction. J Neurosci 2007; 23: 6103-6114. 
36. Parkash J, d'Anglemont de Tassigny X, Bellefontaine N, Campagne C, Mazure D, BueeScherrer V, Prevot V. Phosphorylation of N-methyl-D-aspartic acid receptor-associated neuronal nitric oxide synthase depends on estrogens and modulates hypothalamic nitric oxide production during the ovarian cycle. Endocrinology 2010; 6: 2723-2735.

37. Smith JT, Dungan HM, Stoll EA, Gottsch ML, Braun RE, Eacker SM, Clifton DK, Steiner RA. Differential regulation of KiSS-1 mRNA expression by sex steroids in the brain of the male mouse. Endocrinology 2005; 7: 2976-2984.

38. Smith JT, Cunningham MJ, Rissman EF, Clifton DK, Steiner RA. Regulation of Kiss1 gene expression in the brain of the female mouse. Endocrinology 2005; 9: 3686-3692.

39. Clasadonte J, Poulain P, Beauvillain JC, Prevot V. Activation of neuronal nitric oxide release inhibits spontaneous firing in adult gonadotropin-releasing hormone neurons: a possible local synchronizing signal. Endocrinology 2008; 2: 587-596.

\section{FIGURE LEGENDS}

Figure 1. Neuroanatomical relationship between kisspeptin and nNOS in ewes. Lower magnification image illustrating nNOS (green) and kisspeptin (red) staining in a representative ARC section (A). Two neurons containing both nNOS and kisspeptin (B-D). Kisspeptin closecontacts (arrows) were observed in association with nNOS neurons (E-G). Scale bar in A = 500 $\mu \mathrm{m}$. Scale bar in $\mathrm{B}$ and $\mathrm{E}=50 \mu \mathrm{m}$.

Figure 2. Neuroanatomical relationship between GnRH and nNOS in ewes. Lower magnification image illustrating nNOS (green) and GnRH (red) staining in a representative POA 
section (A). A neuron containing both nNOS and GnRH (B-D). GnRH close-contacts (arrow) were observed in association with nNOS neurons (E-G). Scale bar in A $=500 \mu \mathrm{m}$. Scale bar in $\mathrm{B}$ and $\mathrm{E}=50 \mu \mathrm{m}$.

Figure 3. Neuroanatomical relationship between kisspeptin and nNOS in female primates. Lower magnification image illustrating nNOS (green) and kisspeptin (red) staining in a representative MBH section (A). Colocalization between kisspeptin and nNOS was not observed (B). Kisspeptin close-contacts (arrows) were observed in association with nNOS neurons (C). Scale bar in A $=500 \mu \mathrm{m}$. Scale bar in B and C $=10 \mu \mathrm{m}$.

Figure 4. Neuroanatomical relationship between GnRH and nNOS in female primates. Lower magnification image illustrating nNOS (green) and GnRH (red) staining in a representative MBH section (A). A neuron containing both nNOS and GnRH (B-D). A nNOS neuron with a GnRH close-contact (arrow) (E-G). Scale bar in A $=500 \mu \mathrm{m}$. Scale bar in B and $E=20 \mu \mathrm{m}$. 
Table 1. Comparison of percent colocalization of kisspeptin and nNOS and GnRH and nNOS in adult female sheep and primates.

\begin{tabular}{|c|c|c|c|c|}
\hline Animal Model & \%Kiss/nNOS & \%nNOS/Kiss & \%GnRH/nNOS & \%nNOS/GnRH \\
\hline Sheep & $98.8 \pm 3.5$ & $51.3 \pm 4.0$ & $15.0 \pm 4.2$ & $3.8 \pm 1.8$ \\
\hline \multirow{2}{*}{ Primate } & No colocalization & No colocalization & $38.8 \pm 10.1$ & $13.8 \pm 6.3$ \\
\hline
\end{tabular}

Values are expressed as the mean \pm SEM. \% Kiss/nNOS; percentage of kisspeptin neurons in the ARC containing nNOS. \%nNOS/Kiss; percentage of nNOS neurons in the ARC containing kisspeptin. \%GnRH/nNOS; percentage of GnRH neurons in the POA of sheep and MBH of primates containing nNOS. \%nNOS/GnRH; percentage of nNOS neurons in the POA of sheep and MBH of primates containing GnRH. 
Figure 1

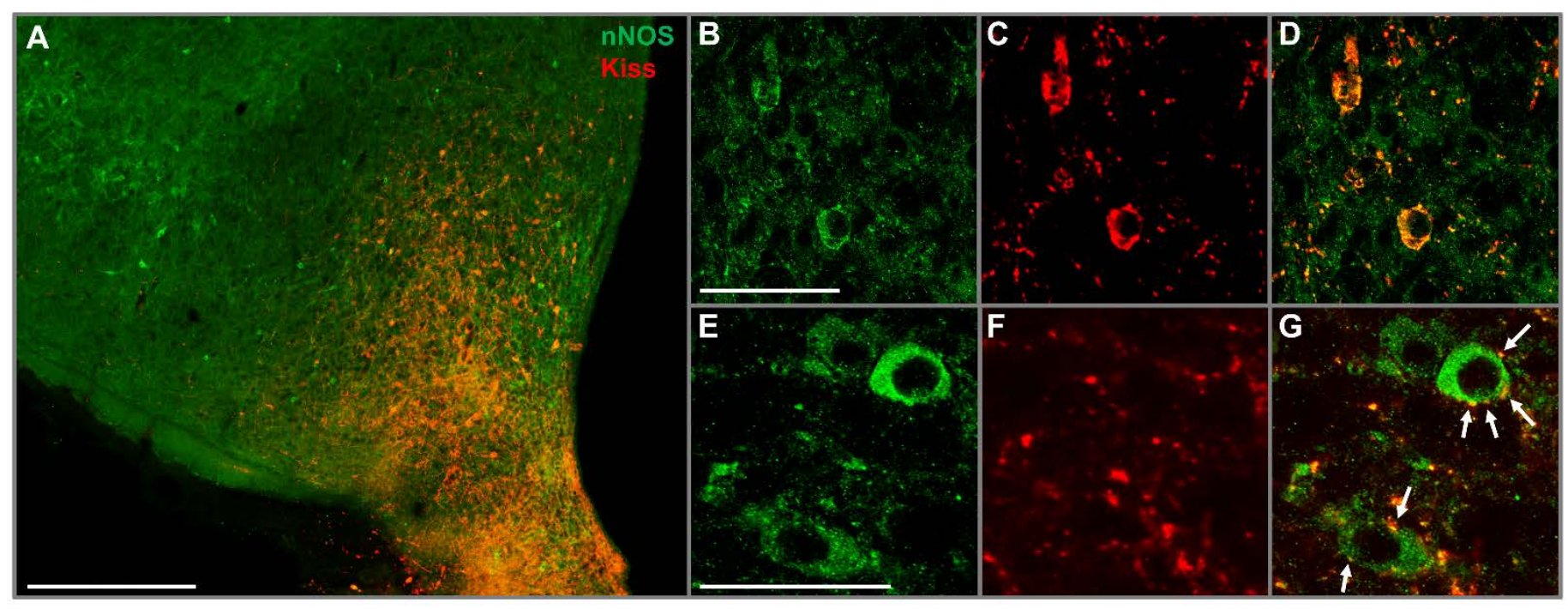


Figure 2

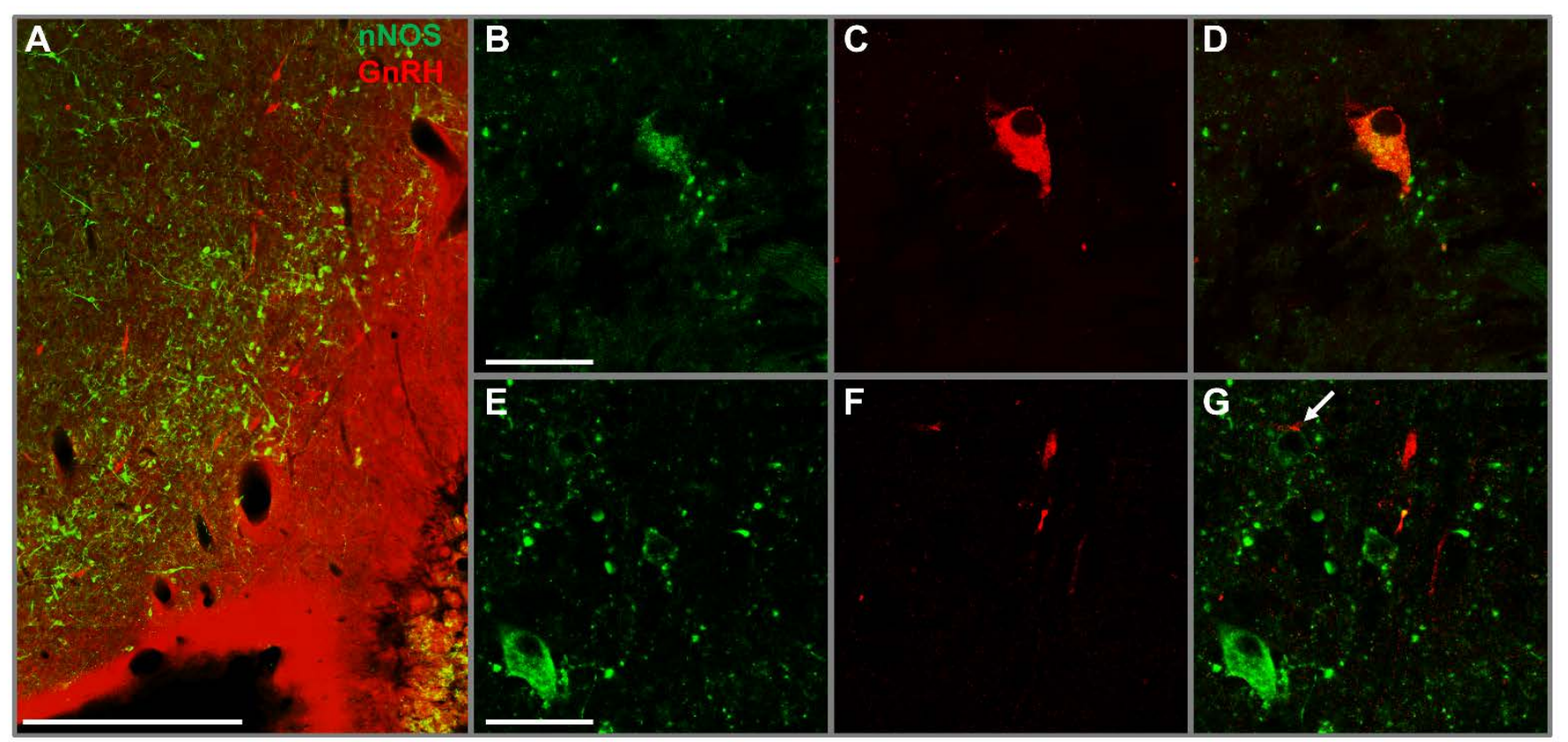


Figure 3




Figure 4

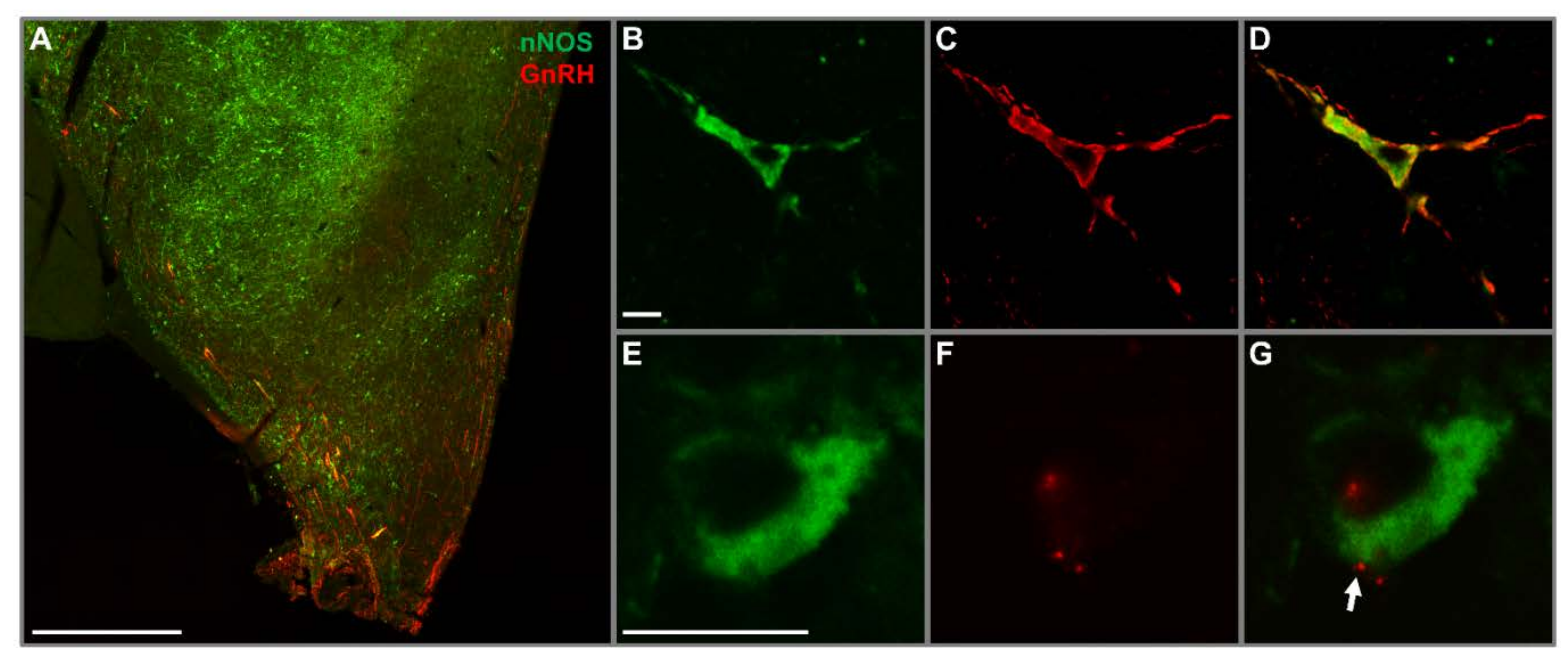




\section{Supplemental Figure 1}

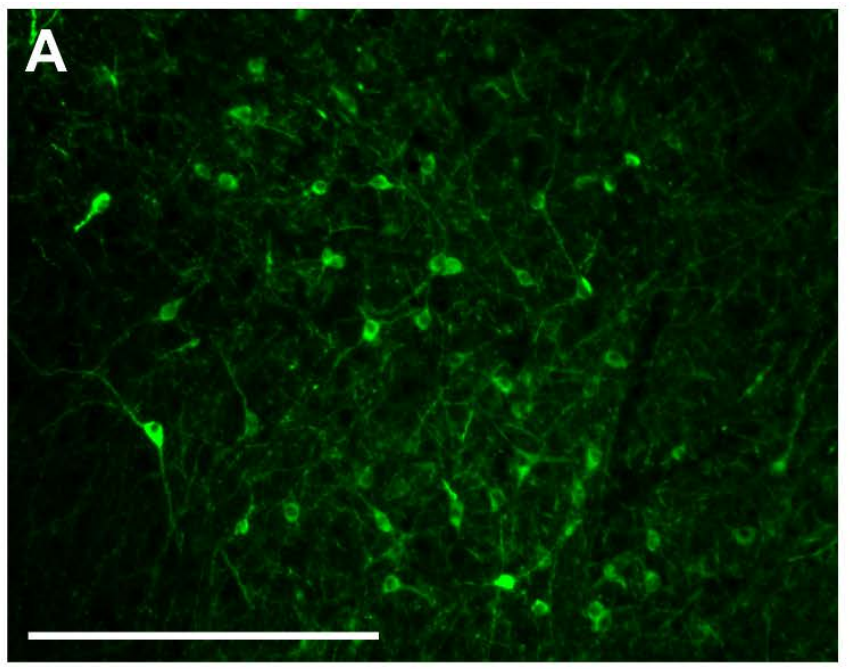

\section{B}

Supplemental Figure 1. nNOS antibody validation in female primates. Low magnification image depicting nNOS-immunoreactive neurons after exposure to rabbit anti-nNOS antibody (A). Low magnification image depicting no nNOS-immunoreactive neurons after exposure to rabbit antinNOS antibody that was preadsorbed with nNOS peptide (B.). Scale bars $=500 \mu \mathrm{m}$. 


\section{Supplemental Figure 2}

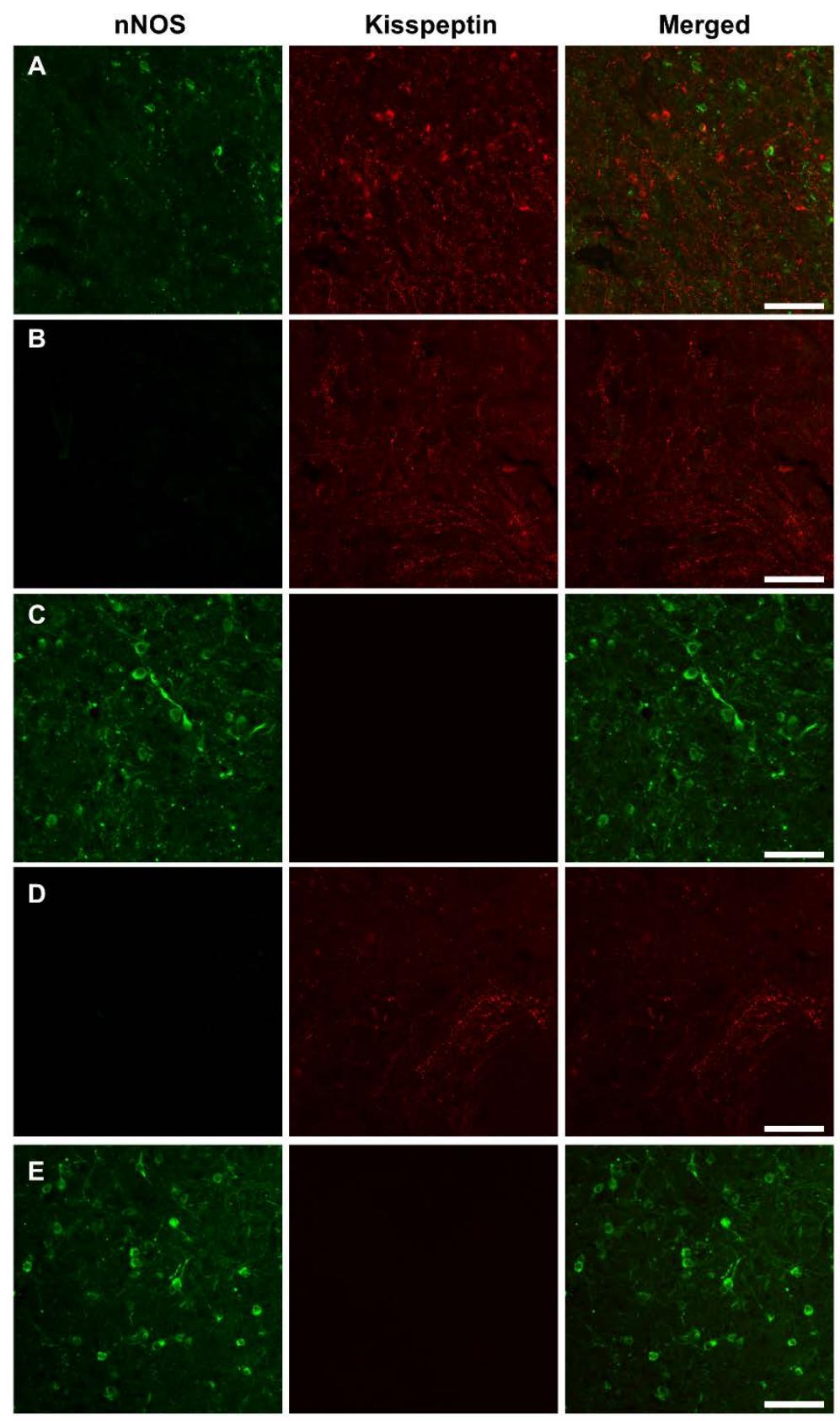

Supplemental Figure 2. Kisspeptin and nNOS immunohistochemistry controls in female

primates. Positive control (A). Kisspeptin antibody preadsorbed with nNOS peptide (B). nNOS antibody preadsorbed with kisspeptin peptide (C). nNOS antibody omitted (D). Kisspeptin antibody omitted. Scale bars $=50 \mu \mathrm{m}$. 


\section{Supplemental Figure 3}



Supplemental Figure 3. GnRH and nNOS immunohistochemistry controls in female primates.

Positive control (A). GnRH antibody preadsorbed with nNOS peptide (B). nNOS antibody

preadsorbed with GnRH peptide (C). nNOS antibody omitted (D). GnRH antibody omitted (E).

Scale bars $=50 \mu \mathrm{m}$. 
CHAPTER 5

GENERAL DISCUSSION 
Prior to the completion of this dissertation, a limited number of studies had examined the role of kisspeptin, NKB, and dynorphin in puberty onset in sheep. While these studies implicated a role for NKB and dynorphin, the exact location(s) within the hypothalamus where these two neuropeptides were acting to influence LH secretion in prepubertal ewes remained to be determined. The preceding chapters of this dissertation reveal senktide placement in the POA or ARC of prepubertal ewes stimulates LH secretion whereas nor-BNI placement into these locations has no significant effect on LH secretion. Additionally, the number of NK3R neurons increases in the POA as ewes transition from a prepubertal to an adult state.

Previous work in rodents has also implicated an important role for NO in puberty. However, few studies have characterized the NO system in species other than mice and rats. Herein I examined the neuroanatomical relationship of nNOS to GnRH or kisspeptin in sheep. Neuronal NOS neurons are abundantly expressed throughout the POA and hypothalamus of prepubertal sheep. These neurons are also highly colocalized with kisspeptin and GnRH in prepubertal sheep; a result that is in contrast to what has previously been reported in adult rodents. Because of this discrepancy between species, and to examine a potential effect of age or phase of reproductive cycle on these relationships, we also determined if nNOS colocalized with kisspeptin and GnRH in adult female sheep and nonhuman primates during the follicular or luteal phase. Similar to prepubertal ewes, kisspeptin neurons in adult ewes were highly colocalized with nNOS. In contrast, no colocalization was observed between kisspeptin and nNOS in adult female primates. Gonadotropin-releasing hormone neurons also colocalized with nNOS in adult ewes and primates, albeit to a much lesser extent than what was observed in prepubertal ewes. We observed no effect of phase of reproductive cycle on any of these 
relationships. This section will attempt to provide an inclusive picture of where our data fit in the context of current findings and identify important questions that remain to be answered.

\section{NKB AND DYNORPHIN IN PUBERTY}

An increase in GnRH and LH secretion is critical for puberty onset in sheep. However, the neural mechanisms that underlie this increase in secretion are not completely understood. Previous studies from our lab revealed administering senktide I.V. could stimulate LH secretion in prepubertal ewes (1). Where senktide was acting to cause this stimulation in LH secretion remained to be determined. With this work, we demonstrated administration of senktide into either the POA or ARC significantly increases mean LH concentrations. The increase observed after placement in the ARC was similar in magnitude and appearance to that observed in our previous work using adult ewes (2). In contrast, the increase in mean LH concentrations in response to senktide placement in the POA in prepubertal ewes was much smaller than what was previously observed in adult ewes (2). Thus, changes in responsiveness to NKB may occur in the POA as ewes mature. While this change in responsiveness may be the result of several underlying mechanisms, increases in NK3R expression could be one factor contributing to this difference in response. In this work, we found that the number of NK3R-positive neurons increases in the POA as ewes transition from a prepubertal to an adult state. Based on this, we would suggest that changes in response to NKB within the POA may be important for puberty onset (Figure 1). Importantly, NK3R-containing cell numbers in the POA are not the only aspect of the KNDy system that is changing in an age-associated manner. Postpubertal increases in the number of kisspeptin neurons also occur in the POA of mice (3) and the ARC of sheep (1). Additionally, the percentage of GnRH neurons depolarized by kisspeptin also increases as mice 
mature from a juvenile to an adult state (4). It is also possible that NK3R mRNA abundance and protein content may be changing in neurons throughout the POA and hypothalamus which are characteristics we did not analyze in this study. Of note, it is important to remember that immunohistochemistry is binary in nature. Thus, changes in receptor expression above a certain threshold may be occurring that, while altering the response of the cell to NKB, are not detected using this technique. Additional studies are needed to identify if changes in NK3R mRNA abundance occur in the presence or absence of changes in the number of NK3R neurons detected using immunohistochemistry in this study. Moreover, techniques that have been employed in mice for labeling kisspeptin neurons in situ with green fluorescent protein (GFP) would be advantageous for identifying NK3R-containing neurons. Slice preparations could then be used to determine true responsiveness to NKB in a single NK3R-containing neuron.

While implants of senktide revealed that stimulation of NK3R-containing cells in the POA or ARC increases mean LH concentrations, it does not answer the question of whether these cells are physiologically involved in regulating LH secretion. Area-specific deletion of NK3Rcontaining neurons would provide an answer to this question. One approach would be to use a technique that interferes with gene expression, such as local small interfering RNA (siRNA) injection or knockdown using an approach such as CRISPR-CAS9. To date, our attempts to use these approaches have been unsuccessful. An alternative approach would be to locally inject a saporin-conjugated NK3R molecule. These studies are ongoing, and preliminary data indicate that deletion of NK3R-containing cells using this approach is feasible. Previous work in rats demonstrated that injection of NK3R-saporin into the ARC reduced the increase in LH secretion seen post-ovariectomy (5). The caveat with this approach is that the use of saporin destroys the entire neuron. Therefore, identifying the involvement of specific cell products is difficult. 
Moreover, the identity of cells expressing NK3R in areas outside the ARC is largely unknown. Within the ARC, KNDy neurons express NK3R, and preliminary work from our lab has also identified a high level of NK3R expression in pro-opiomelanocortin (POMC) and agouti-related peptide (AgRP) neurons. Altogether, increases in NK3R expression, changes in other aspects of the KNDy system, and actions of other factors that remain to be identified are all underlying mechanisms that may influence changes in responsiveness to NKB in the POA of ewes.

In contrast to what was observed with senktide administration, placement of nor-BNI into the POA or ARC did not have a significant effect on LH secretion. Infusion of nor-BNI into the lateral ventricle increases mean LH concentrations and LH pulse frequency in ewes of a prepubertal, but not postpubertal, age (6). In addition, a high percentage of kisspeptin neurons in the POA and ARC, as well as GnRH neurons in the POA and hypothalamus, of ewes colocalize with $\operatorname{KOR}(6,7)$. Therefore, we hypothesized that dynorphin would act in the POA and/or ARC of prepubertal ewes to block GnRH release. However, we found that blocking KORs separately in the POA or ARC of prepubertal ewes did not significantly influence LH secretion. Redundancy may exist in regard to dynorphin input and that blockade of KORs in multiple locations in the brain is required to affect LH secretion in prepubertal ewes. Addressing this possibility would require the simultaneous application of nor-BNI to the ARC and POA. Dynorphin may also be binding to KORs in areas outside of the POA or ARC to inhibit LH secretion. In addition to being present in the POA and ARC, KOR is found in several other areas of the hypothalamus in sheep (7). Interestingly, our previous work (6) failed to demonstrate dynorphin expression within the ARC of prepubertal OVX or OVX+E ewes even though immunostaining was readily evident in the ARC from ewes in the luteal phase of the estrous cycle that was processed concurrently with the prepubertal tissue. An absence of dynorphin 
staining may have been due to low levels of dynorphin protein synthesis that were below the detection limit of immunohistochemistry, rapid transport of dynorphin out of the ARC following synthesis, or simply a lack of dynorphin in the ARC due to a lack of progesterone (8).

Dynorphin is hypothesized to be the signal arising from KNDy neurons that is responsible for terminating a GnRH/LH pulse. Therefore, while dynorphin may serve as a component of the pulse generator in adult ewes, it may not play a critical role in the onset of puberty in this species. Future studies are needed to parse out the source of dynorphin that inhibits LH secretion in prepubertal ewes as well as the exact location(s) wherein dynorphin action is occurring. 

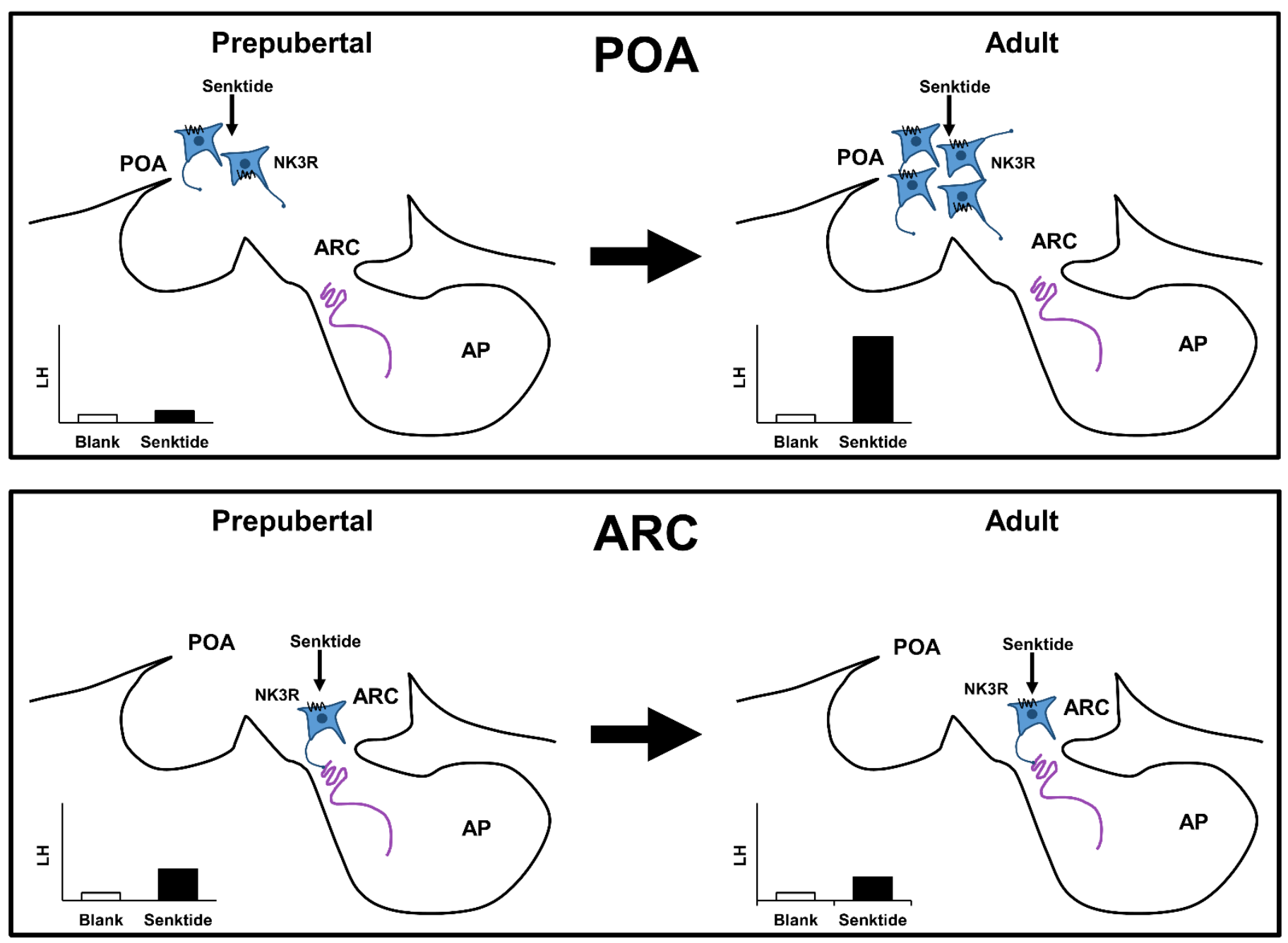

Figure 1. Comparison of the response to senktide and the number of NK3R neurons in the POA and ARC between prepubertal and adult ewes. In the POA, there is a larger increase in LH concentrations following senktide treatment in adult ewes than prepubertal ewes. Coincident with this increased response, there is an increased number of NK3R neurons in the POA of adult ewes (Top Panel). In the ARC, prepubertal and adult ewes exhibit a similar LH response after senktide treatment, and there is a small number of NK3R neurons in the ARC at both ages (Bottom Panel).

\section{nNOS IN PREPUBERTAL SHEEP}

Data gathered while performing experiments presented in Chapter 3 demonstrate there is a significant number of nNOS neurons distributed throughout the POA and hypothalamus of 
prepubertal sheep, and this distribution compares well to previous reports in mice (9), rats (10), nonhuman primates (11), and humans (12). The presence of a large number of nNOS neurons in these areas of the brain is not surprising given the fact that NO influences countless physiological processes within the body (13). In addition to the significant number of nNOS neurons found in the POA and hypothalamus of prepubertal ewes, we also observed a high degree of ER $\alpha$ expression in nNOS neurons. Because of this, we hypothesized nNOS neurons may play a role in the communication of $E_{2}$ negative feedback in prepubertal ewes and that $E_{2}$ treatment would alter nNOS expression, either generally or in a region-specific manner. However, we did not observe an effect of $\mathrm{E}_{2}$ on the number of nNOS neurons present nor the percentage of nNOS neurons that contained ER $\alpha$ in any of the hypothalamic areas examined. Importantly these results do not mean that $\mathrm{E}_{2}$ is not affecting other aspects of this system. Both nNOS and ER $\alpha$ mRNA abundance and protein content within specific cells may be sensitive to $\mathrm{E}_{2}$. As mentioned previously, immunohistochemistry is a binary technique and physiologically important, but perhaps subtler changes could be occurring within cells that are not detected using this approach. Estradiol could also affect the relationship of nNOS to other neuronal intermediates. For example, in this work there was a trend for $\mathrm{E}_{2}$ to decrease the number of kisspeptin close-contacts onto nNOS neurons in the ARC of prepubertal ewes. Thus, this may be one of the ways $\mathrm{E}_{2}$ regulates nNOS neurons in prepubertal sheep, and the ARC in particular may be an important area where this regulation occurs.

In addition to characterizing the distribution of nNOS neurons in the POA and hypothalamus of prepubertal sheep and determining that a subset of these neurons contain ER $\alpha$, we also discovered that a high percentage of kisspeptin and GnRH neurons colocalize with nNOS (Figure 2). These results are in stark contrast to what has previously been reported in adult mice 
(14) and rats (15). Because similar data was found in adult sheep in experiments from Chapter 4 of this dissertation, it appears the differences between nNOS and kisspeptin from our prepubertal study and the adult rodent studies are most likely due to species differences and are not a result of age-associated changes (Figure 2). However, there were significantly fewer GnRH neurons in the POA of adult sheep that colocalized with nNOS than in prepubertal sheep (Figure 2). This might suggest that NO serves as an inhibitor of GnRH secretion in prepubertal ewes, since the influence of $E_{2}$ on $\mathrm{GnRH}$ pulse frequency is less in adult ewes compared to prepubertal ewes. In addition, GnRH close-contacts onto nNOS neurons were observed in adult but not prepubertal ewes (Figure 2). One possible interpretation of these data is that since nNOS neurons begin to exhibit GnRH close-contacts, GnRH may exert feedback to inhibit NO release from these neurons. Altogether, these processes would aid in decreasing NO-ergic inhibition of GnRH release. Functional studies are required to validate these hypotheses and elucidate how NO acts to influence LH secretion in prepubertal ewes. To date, we have tried in two separate studies to inject the NOS inhibitor, L-NAME, into either the lateral or third cerebroventricle and assess its effect on LH secretion. In neither case did we get a significant effect of L-NAME administration on LH secretion in prepubertal ewes. Currently, there is a paucity of data examining NOS inhibition and LH secretion. Previous work in adult anestrous ewes showed varying effects of NOS inhibitor placement in the POA on LH secretion (16). In mid-anestrus, microimplants containing L-NAME, but not the specific nNOS inhibitor, SMTC, significantly increased LH pulse frequency. In late anestrus, a different nNOS inhibitor, 7NI, increased LH pulse frequency, but L-NAME or SMTC had no effect (16). Altogether, it appears NO may inhibit LH secretion by acting in the POA of anestrous ewes, and this inhibition may be stronger during mid anestrus rather than late anestrus. In female mice, intraperitoneal injection of a NOS inhibitor 
increased LH release when given during the diestrous phase of the estrous cycle. In contrast, injection of this inhibitor blocked the LH surge (14). Recent preliminary data from our lab also indicates that infusion of L-NAME into the $3^{\text {rd }}$ ventricle may block the LH surge in adult ewes. Therefore, NO appears to inhibit LH secretion under steroid negative feedback conditions but stimulates LH secretion during steroid positive feedback conditions.

Figure 2
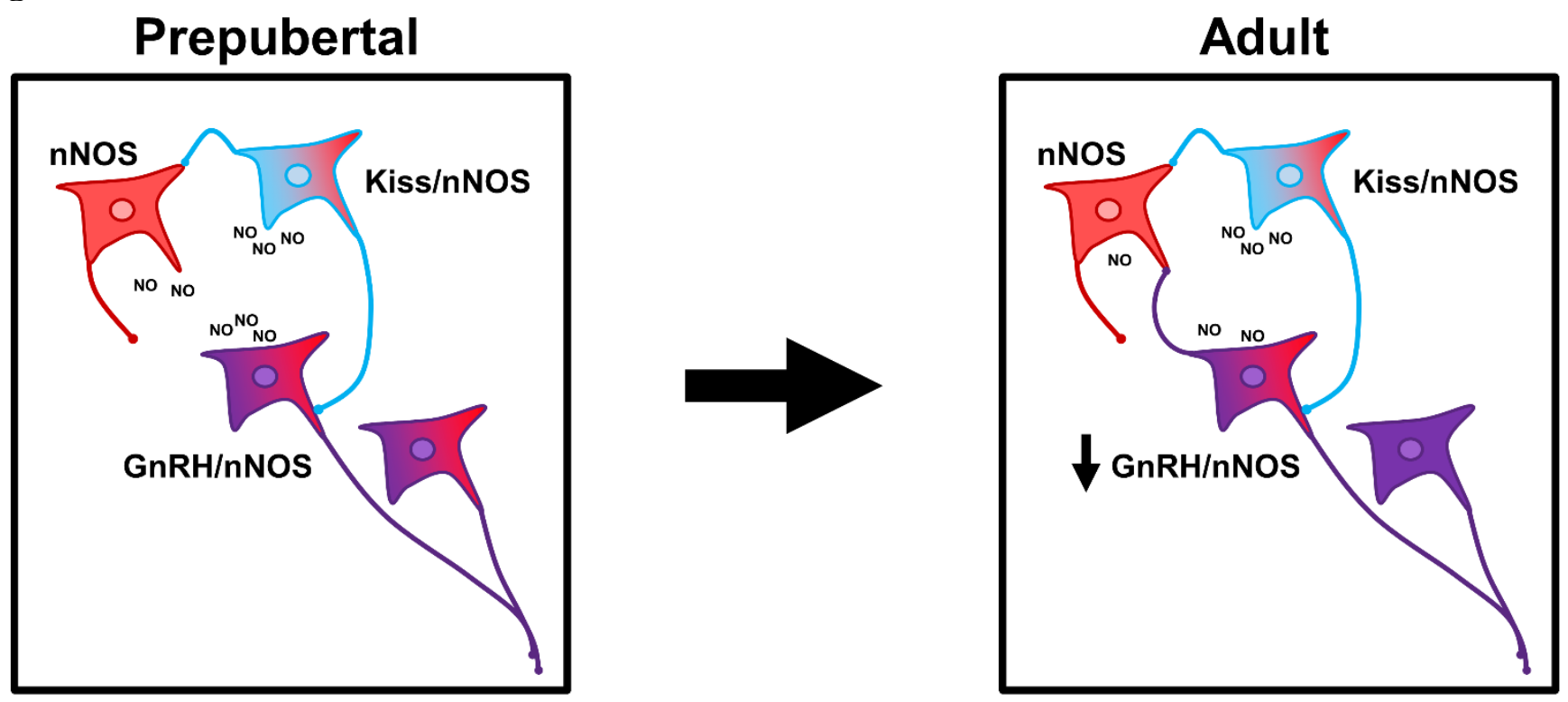

Figure 2. The neuroanatomical relationship of nNOS with kisspeptin and GnRH in prepubertal and adult ewes. A high percentage of GnRH and kisspeptin neurons colocalize with nNOS in prepubertal ewes. Kisspeptin close-contacts are also present on nNOS neurons, but GnRH closecontacts are not observed (left). In adult ewes, a high percentage of kisspeptin neurons colocalize with nNOS, but significantly fewer GnRH neurons colocalize with nNOS than is observed in prepubertal ewes. Both kisspeptin and GnRH close-contacts are found on nNOS neurons in adult ewes (right). 


\section{nNOS IN ADULT SHEEP AND PRIMATES}

In addition to delineating the relationship of nNOS to kisspeptin and GnRH in prepubertal ewes, we also examined this relationship in adult female nonhuman primates and ewes in either the follicular or luteal phase. In both ewes and female rhesus monkeys, a subset of GnRH neurons colocalized with nNOS, and GnRH and kisspeptin close-contacts were observed onto nNOS neurons. In the ARC of ewes, a high percentage of kisspeptin neurons colocalized with nNOS. In contrast, we did not observe any colocalization between kisspeptin and nNOS in adult female rhesus monkeys which is consistent with what has previously been observed in mice (14). As assessed by immunohistochemistry, phase of cycle did not have an effect on any of these relationships. These results are in agreement with findings from our prepubertal sheep study where the presence or absence of $E_{2}$ only had an effect on the number of kisspeptin closecontacts onto nNOS neurons in the ARC and not percent colocalization between these neuronal populations. Therefore, nNOS/kisspeptin and nNOS/GnRH coexpression is either not influenced significantly by sex steroids, or sex steroids influence other functionally important connections between nNOS and kisspeptin/GnRH in sheep and nonhuman primates. Other functionally important changes could include the ability of kisspeptin to increase the phosphorylation, and thus catalytic activity, of nNOS which has been observed in mice (14). We tried to assess expression of phosphorylated nNOS in our sheep tissue, but a commercially available antibody that appears to work in mice did not work appropriately in our sheep tissue (17). The release of kisspeptin or NO may also be affected by concentrations of sex steroids. Further studies are needed to determine if this is indeed the case in sheep or nonhuman primates. However, both would be difficult to assess with any degree of accuracy using methods currently available in either species. 
Overall, the relationship of nNOS to kisspeptin and GnRH was very similar between adult ewes and nonhuman primates indicating that, in this instance, sheep may serve as a good model for humans. The only major difference between the two species was that kisspeptin neurons in nonhuman primates did not colocalize with nNOS. These results are much more akin to what has been reported for mice, i.e. no colocalization in either the POA or ARC (14). Thus, the relationship between nNOS and kisspeptin may be species dependent. Differences in perfusion techniques, immunohistochemistry protocols, or other methodological differences between studies may have also led to the heterogeneity of results between species. Additionally, it cannot be determined whether an increase in colocalization between two neuronal populations is due to an increase in peptide synthesis or a lack of peptide release. Other techniques besides immunohistochemistry would be required to answer these questions. A summary of what is currently known about the relationship of nNOS to kisspeptin and GnRH in adult rodents, sheep, and nonhuman primates can be found in Table 1.

Table 1. A comparison of the relationship of nNOS to kisspeptin and GnRH in rodent, sheep, and nonhuman primate models.

\begin{tabular}{cccc}
\hline & Rodents & Sheep & Nonhuman \\
\hline $\begin{array}{c}\text { Pisspeptin/nNOS } \\
\text { colocalization }\end{array}$ & no & yes & no \\
$\begin{array}{c}\text { Kisspeptin close- } \\
\text { contacts onto } \\
\text { nNOS neurons }\end{array}$ & yes & yes & yes \\
$\begin{array}{c}\text { GnRH/nNOS } \\
\text { colocalization }\end{array}$ & no & yes & yes \\
$\begin{array}{c}\text { GnRH close- } \\
\text { contacts onto } \\
\text { nNOS neurons }\end{array}$ & n/a & yes & yes \\
\hline
\end{tabular}




\section{SUMMARY}

The data herein demonstrate NKB can act in both the POA and ARC of prepubertal ewes to influence LH secretion, and the POA in particular seems to be an important site for pubertyrelated changes to the NKB system. Neuronal NOS neurons are abundantly expressed in the POA and hypothalamus of prepubertal ewes and colocalize with ER $\alpha$, kisspeptin, and GnRH. A high percentage of nNOS neurons also colocalize with kisspeptin in adult ewes. However, the percentage of GnRH neurons that colocalize with nNOS is significantly lower in adult ewes compared to prepubertal ewes. Therefore, decreases in GnRH colocalization with nNOS appears to occur as ewes transition from a prepubertal to an adult state. Finally, while species differences do exist, our results in adult female nonhuman primates compare well with our findings in adult ewes indicating sheep may serve as a good model for examining how these neuroanatomical relationships function in humans.

\section{REFERENCES}

1. Nestor CC, Briscoe AM, Davis SM, Valent M, Goodman RL, Hileman SM. Evidence of a role for kisspeptin and neurokinin B in puberty of female sheep. Endocrinology 2012; 6: 27562765.

2. Porter KL, Hileman SM, Hardy SL, Nestor CC, Lehman MN, Goodman RL. Neurokinin-3 receptor activation in the retrochiasmatic area is essential for the full pre-ovulatory luteinising hormone surge in ewes. J Neuroendocrinol 2014; 11: 776-784. 
3. Gill JC, Wang O, Kakar S, Martinelli E, Carroll RS, Kaiser UB. Reproductive hormonedependent and -independent contributions to developmental changes in kisspeptin in GnRHdeficient hypogonadal mice. PLoS One 2010; 7: e11911.

4. Han SK, Gottsch ML, Lee KJ, Popa SM, Smith JT, Jakawich SK, Clifton DK, Steiner RA, Herbison AE. Activation of gonadotropin-releasing hormone neurons by kisspeptin as a neuroendocrine switch for the onset of puberty. J Neurosci 2005; 49: 11349-11356.

5. Mittelman-Smith MA, Williams H, Krajewski-Hall SJ, Lai J, Ciofi P, McMullen NT, Rance NE. Arcuate kisspeptin/neurokinin B/dynorphin (KNDy) neurons mediate the estrogen suppression of gonadotropin secretion and body weight. Endocrinology 2012; 6: 2800-2812.

6. Lopez JA, Bedenbaugh MN, McCosh RB, Weems PW, Meadows LJ, Wisman B, Coolen LM, Goodman RL, Hileman SM. Does Dynorphin Play a Role in the Onset of Puberty in Female Sheep?. J Neuroendocrinol 2016; 12: 10.1111/jne.12445.

7. Weems PW, Witty CF, Amstalden M, Coolen LM, Goodman RL, Lehman MN. kappa-Opioid Receptor Is Colocalized in GnRH and KNDy Cells in the Female Ovine and Rat Brain. Endocrinology 2016; 6: 2367-2379.

8. Foradori CD, Goodman RL, Adams VL, Valent M, Lehman MN. Progesterone increases dynorphin a concentrations in cerebrospinal fluid and preprodynorphin messenger ribonucleic Acid levels in a subset of dynorphin neurons in the sheep. Endocrinology 2005; 4: 1835-1842. 
9. Chachlaki K, Malone SA, Qualls-Creekmore E, Hrabovszky E, Munzberg H, Giacobini P, Ango F, Prevot V. Phenotyping of nNOS neurons in the postnatal and adult female mouse hypothalamus. J Comp Neurol 2017.

10. Yamada K, Emson P, Hokfelt T. Immunohistochemical mapping of nitric oxide synthase in the rat hypothalamus and colocalization with neuropeptides. J Chem Neuroanat 1996; 3-4: 295 316.

11. Satoh K, Arai R, Ikemoto K, Narita M, Nagai T, Ohshima H, Kitahama K. Distribution of nitric oxide synthase in the central nervous system of Macaca fuscata: subcortical regions. Neuroscience 1995; 3: 685-696.

12. Sangruchi T, Kowall NW. NADPH diaphorase histochemistry of the human hypothalamus. Neuroscience 1991; 3: 713-724.

13. Garthwaite J. Concepts of neural nitric oxide-mediated transmission. Eur J Neurosci 2008; 11: 2783-2802.

14. Hanchate NK, Parkash J, Bellefontaine N, Mazur D, Colledge WH, d'Anglemont de Tassigny X, Prevot V. Kisspeptin-GPR54 signaling in mouse NO-synthesizing neurons participates in the hypothalamic control of ovulation. J Neurosci 2012; 3: 932-945.

15. Herbison AE, Simonian SX, Norris PJ, Emson PC. Relationship of neuronal nitric oxide synthase immunoreactivity to GnRH neurons in the ovariectomized and intact female rat. J Neuroendocrinol 1996; 1: 73-82. 
16. McManus CJ, Valent M, Hardy SL, Goodman RL. Does nitric oxide act in the ventromedial preoptic area to mediate oestrogen negative feedback in the seasonally anoestrous ewe?. Reproduction 2007; 1: 137-145.

17. Donato J,Jr, Frazao R, Fukuda M, Vianna CR, Elias CF. Leptin induces phosphorylation of neuronal nitric oxide synthase in defined hypothalamic neurons. Endocrinology 2010; 11: 54155427. 